NUREG/CR-5591

ORNL/TM-11568/V6\&N2

Vol. 6, No. 2

\title{
Heavy-Section Steel Irradiation Program
}

RECEIVED

SEP 201996

OSTI

Progress Report for

April-September 1995

Prepared by

W. R. Corwin

Oak Ridge National Laboratory

Prepared for

U.S. Nuclear Regulatory Commission 


\section{AVAILABILITY NOTICE}

Availability of Reference Materials Cited in NRC Publications

Most documents cited in NRC publications will be available from one of the following sources:

1. The NRC Public Document Room, 2120 L Street, NW., Lower Level. Washington, DC 20555-0001

2. The Superintendent of Documents, U.S. Government Printing Office, P. O. Box 37082, Washington, DC 20402-9328

3. The National Technical Information Service, Springfield, VA 22161-0002

Although the listing that follows represents the majority of documents cited in NRC publications, it is not intended to be exhaustive.

Referenced documents available for inspection and copying for a fee from the NRC Public Document Room include NRC correspondence and internal NRC memoranda; NRC bulletins, circulars, information notices, inspection and investigation notices; licensee event reports; vendor reports and correspondence; Commission papers; and appllcant and licensee documents and correspondence.

The following documents in the NUREG series are available for purchase from the Government Printing Office: formal NRC staff and contractor reports, NRC-sponsored conference proceedings, international agreement reports, grantee reports, and NRC booklets and brochures. Also available are regulatory guides, NRC regulations in the Cocte of Federal Regulations, and Nuclear Regulatory Commission Issuances.

Documents available from the National Technical Information Service include NUREG-series reports and technical reports prepared by other Federal agencies and reports prepared by the Atomic Energy Commission, forerunner agency to the Nuclear Regulatory Commission.

Documents available from public and special technical libraries include all open literature items, such as books. journal articles, and transactions. Federal Register notices. Federal and State legislation, and congressional reports can usually be obtained from these libraries.

Documents such as theses, dissertations, foreign reports and translations, and non-NRC conference proceedings are available for purchase from the organization sponsoring the publication cited.

Single copies of NRC draft reports are available free. to the extent of supply, upon written request to the Office of Administration, Distribution and Mail Services Section, U.S. Nuclear Regulatory Commission, Washington, DC 20555-0001.

Coples of industry codes and standards used in a substantive manner in the NRC regulatory process are maintained at the NRC Library. Two White Flint North. 11545 Rockville Pike. Rockville. MD 20852-2738, for use by the public. Codes and standards are usually copyrighted and may be purchased from the originating organization or, if they are American National Standards. from the American National Standards Institute, 1430 Broadway, New York, NY 10018-3308.

\section{DISCLAIMER NOTICE}

This report was prepared as an account of work sponsored by an agency of the United States Govemment. Neither the United States Govemment nor any agency thereof, nor any of their employees, makes any warranty, expressed or implied, or assumes any legal liability or responsibility for any third party's use, or the results of such use, of any information, apparatus, product, or process disclosed in this report, or represents that its use by such third party would not infringe privately owned rights. 
NUREG/CR-5591

ORNL/TM-11568/V6\&N2

Vol. 6, No. 2

\section{Heavy-Section Steel Irradiation Program}

Progress Report for

April-September 1995

Manuscript Completed: January 1996

Date Published: August 1996

Prepared by

W. R. Corwin

Oak Ridge National Laboratory

Managed by Lockheed Martin Energy Research Corporation

Oak Ridge National Laboratory

Oak Ridge, TN 37831-6285

M. G. Vassilaros, NRC Project Manager

Prepared for

Division of Engineering Technology

Office of Nuclear Regulatory Research

U.S. Nuclear Regulatory Commission

Washington, DC 20555-0001

NRC Job Code L1098 


\section{DISCLAIMER}

Portions of this document may be illegible in electronic image products. Images are produced from the best available original document. 


\section{DISCLAIMER}

This report was prepared as an account of work sponsored by an agency of the United States Government. Neither the United States Government nor any agency thereof, nor any of their employees, makes any warranty, express or implied, or assumes any legal liability or responsibility for the accuracy, completeness, or usefulness of any information, apparatus, product, or process disclosed, or represents that its use would not infringe privately owned rights. Reference herein to any specific commercial product, process, or service by trade name, trademark, manufacturer, or otherwise does not necessarily constitute or imply its endorsement, recommendation, or favoring by the United States Government or any agency thereof. The views and opinions of authors expressed herein do not necessarily state or reflect those of the United States Government or any agency thereof. 


\section{Abstract}

Maintaining the integrity of the reactor pressure vessel (RPV) in a light-water-cooled nuclear power plant is crucial in preventing and controlling severe accidents which have the potential for major contamination release. The RPV is the only key safety-related component of the plant for which a duplicate or redundant backup system does not exist. It is therefore imperative to understand and be able to predict the capabilities and limitations of the integrity inherent in the RPV. In particular, it is vital to fully understand the degree of irradiation-induced degradation of the RPV's fracture resistance which occurs during service, since without that radiation damage, it is virtually impossible to postulate a realistic scenario that would result in RPV failure.

For this reason, the Heavy-Section Steel Irradiation (HSSI) Program has been established with its primary goal to provide a thorough, quantitative assessment of the effects of neutron irradiation on the material behavior and, in particular, the fracture toughness properties of typical pressure-vessel steels as they relate to light-water RPV integrity. Effects of specimen size; material chemistry; product form and microstructure; irradiation fluence, flux, temperature, and spectrum; and postirradiation annealing are being examined on a wide range of fracture properties. The HSSI Program is arranged into 14 tasks: (1) program management, (2) fracture toughness curve shift in high-copper weldments (Series 5 and 6), (3) $K_{1 c}$ and $K_{12}$ curve shifts in low upper-shelf (LUS) welds (Series 8), (4) irradiation effects in a commercial LUS weld (Series 10), (5) irradiation effects on weld heat-affected zone (HAZ) and plate materials (Series 11), (6) annealing effects in LUS welds (Series 9), (7) microstructural and microfracture analysis of irradiation effects, (8) in-service irradiated and aged material evaluations, (9) Japan Power Development Reactor (JPDR) steel examination, (10) fracture toughness curve shift method, (11) special technical assistance, (12) tecinical assistance for Joint Coordinating Committee on Civilian Nuclear Reactor Safety (JCCCNRS) Working Groups 3 and 12, (13) correlation monitor materials, and (14) test reactor coordination.

During this period, results of testing the Italian crack-arrest specimens were analyzed and a draft NUREG report prepared. A test plan was developed for irradiation of HSSI weld $73 \mathrm{~W}$ to a high fluence $\left[5 \times 10^{19}\right.$ neutrons $/ \mathrm{cm}^{2}$ $(>1 \mathrm{MeV})]$ to determine whether the $K_{\mathrm{Je}}$ curve shape change observed in the Fifth Series is exacerbated. The fabrication of the third of the three trial LUS scoping welds to identify possible materials for studies on $K_{t c}$ shifts in LUS materials was completed. Data from fracture mechanics testing of specimens of the irradiated LUS Midland Weld WF-70 from both scoping capsules and the first large capsule [exposed to 0.5 and $1.0 \times 10^{19}$ neutrons $/ \mathrm{cm}^{2}$ $(>1 \mathrm{MeV})$, respectively] was completed and the results reported. Precracked Charpy specimens of beltline weld were also tested in the unirradiated and irradiated conditions and showed an irradiation-induced fracture toughness shift very close to that indicated by the compact specimens. The second large capsule that was shipped to Oak Ridge National Laboratory (ORNL) has been disassembled, and the specimens are awaiting testing in the hot cell. Arrangements were made with Yankee Atomic Electric Company for the procurement of two A 302 grade B plates, identified for examination of the effects of neutron irradiation on the fracture toughness of the HAZ of welds of plate materials typical of those used in fabricating older RPVs. Microstructural characterizations of long-term $(\sim 100,000 \mathrm{~h})$ thermally aged, neutron-irradiated, and annealed surveillance materials were completed. An atom-probe field-ion microscopy characterization of a simple thermally aged model alloy was performed to investigate its suitability as a model for commercial RPV steels. The validity of the low-load "nanoindentation" technique to monitor strength changes was established. A comparison of model predictions and available data seemed to confirm that the lead factors commonly employed in commercial surveillance programs should have negligible impact on the validity of the data obtained. Modification of the computer numerically controlled machining center for irradiated materials continued with the completion of the drawings, new cables and table, machine enclosure, fittings, and a floor tub for installation inside the hot cell. Tensile and Charpy V-notch impact tests of type 308 stainless steel weld metals aged at $343^{\circ} \mathrm{C}$ for up to $50,000 \mathrm{~h}$ showed that aging had little effect on the tensile properties, but did result in embrittlement as shown by the impact testing. The baseline testing for the cross comparison of the effects of the different tups used in U.S. and Japanese Charpy impact machines was performed to provide a basis for understanding any differences that might later arise from jointly testing the JPDR materials. Available fracture toughness databases were analyzed for plates, forgings, and welds, and it was shown that, on average, the fracture toughness shifts generally exceeded the Charpy $41-\mathrm{J}$ shifts by about 20,50 , and $8 \%$ for plates, forgings, and welds, respectively. Overall, the fracture toughness shifts exceed the CVN shifts by about $14 \%$, similar to the results reported previously from analysis of HSSI Program data. Evaluation of the precracked cylindrical tensile specimen continued with a report produced for ORNL by SRI International and AEA Technology, Harwell, United Kingdom, regarding their test results. A detailed plan was developed for removal of material from the pressurized-water RPV, the Pressure Vessel Research User's Facility located at the Oak Ridge Gaseous Diffusion Plant (K-25 site). The remaining correlation monitor materials were moved from the storage area at the Y-12 Plant and placed into the HSSI storage facility at the ORNL site. Two blocks of Heavy-Section Steel 
Technology (HSST) plate 03 were sent to the Hanjung America Corp. for use as correlation monitor materials in Units 3 and 4 of the Ulchin Nuclear Power Plant in Korea. Most of the engineering drawings for the irradiation facility and specimen baskets for University of California, Santa Barbara, irradiations were completed, and procurement and fabrication of selected portions of the facility were initiated. 
Page

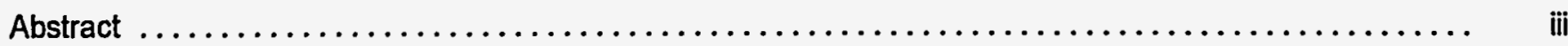

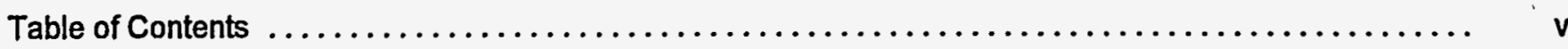

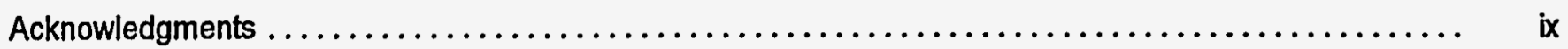

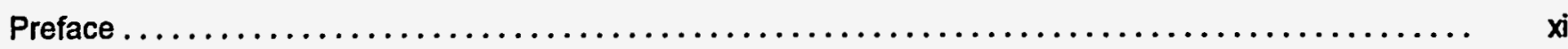

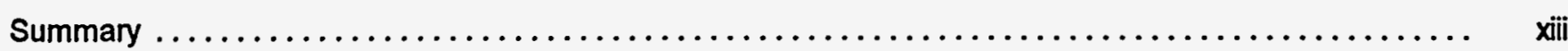

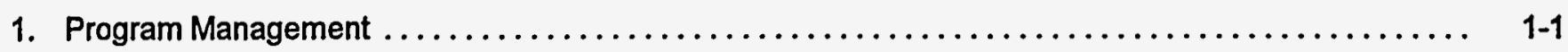

2. Fracture Toughness Shifts in High-Copper Weldments (Series 5 and 6$) \ldots \ldots \ldots \ldots \ldots \ldots \ldots \ldots \ldots$

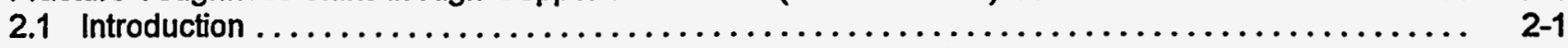

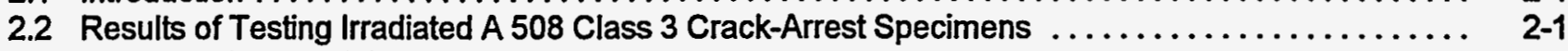

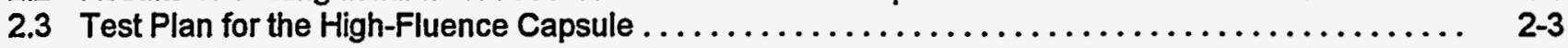

3. Fracture Toughness Curve Shifts in Low Upper-Shelf Welds (Series 8) $\ldots \ldots \ldots \ldots \ldots \ldots \ldots \ldots$ 3-1

4. Irradiation Effects in a Commercial Low Upper-Shelf Weld (Series 10) ................. 4-1

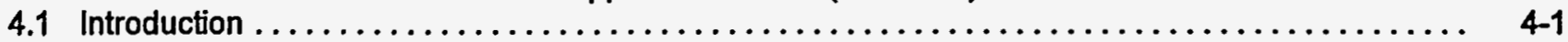

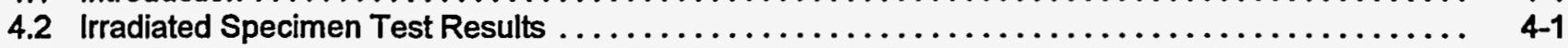

4.3 Crack-Arrest Toughness of WF-70 Weld Metal Specimens $\ldots \ldots \ldots \ldots \ldots \ldots \ldots \ldots \ldots \ldots \ldots$

5. Irradiation Effects on Weld Heat-Affected Zone and Plate Materials (Series 11) ............ 5-1

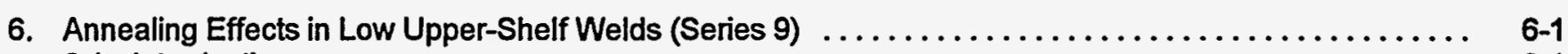

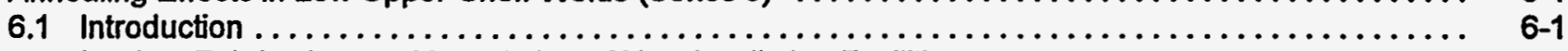

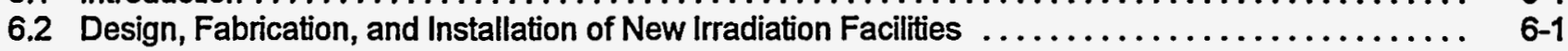

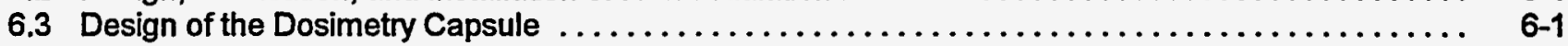

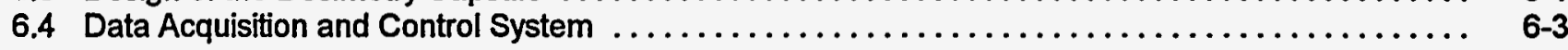

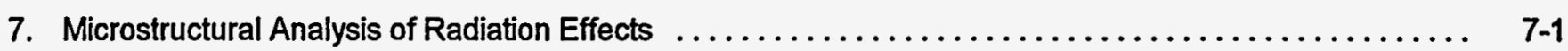

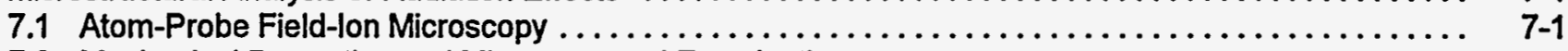

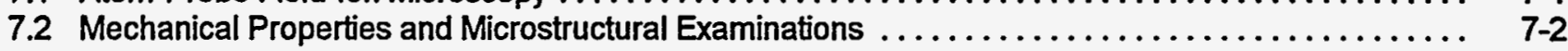

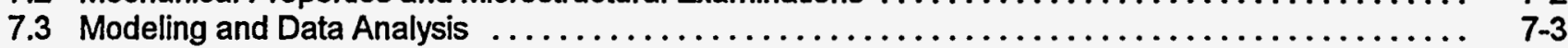

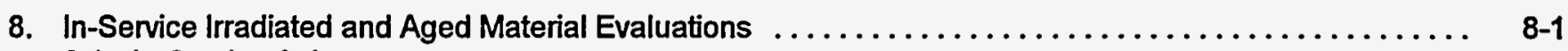

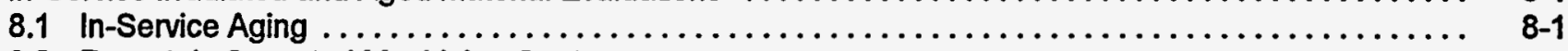

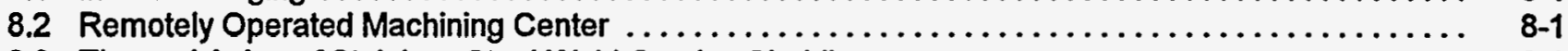

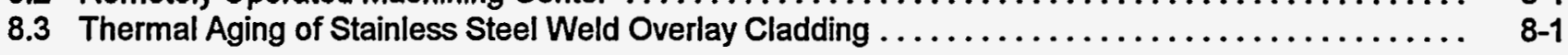

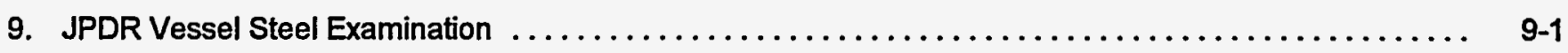

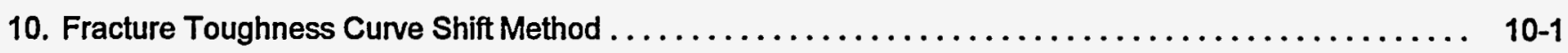


11. Special Technical Assistance $\ldots \ldots \ldots \ldots \ldots \ldots \ldots \ldots \ldots \ldots \ldots \ldots \ldots \ldots \ldots \ldots \ldots \ldots \ldots \ldots \ldots \ldots \ldots .11$

11.1 Plan to Survey Variability in Chemical, Mechanical, and Toughness Properties of the

Pressure Vessel Research Users Facility Reactor Vessel .

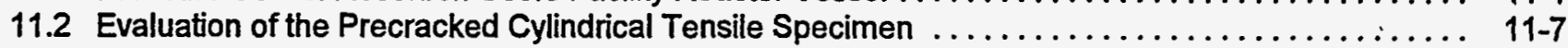

11.3 Initial Evaluation of Subsize Charpy V-Notch Testing $\ldots \ldots \ldots \ldots \ldots \ldots \ldots \ldots \ldots \ldots \ldots \ldots \ldots$

12. Technical Assistance for JCCCNRS Working Groups 3 and $12 \ldots \ldots \ldots \ldots \ldots \ldots \ldots \ldots \ldots \ldots$

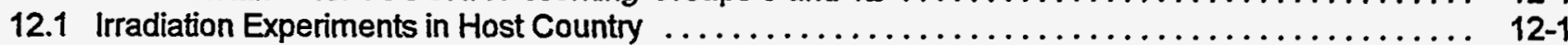

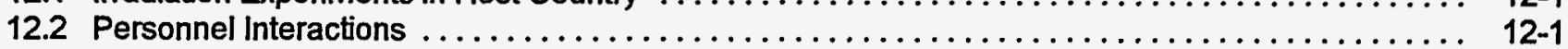

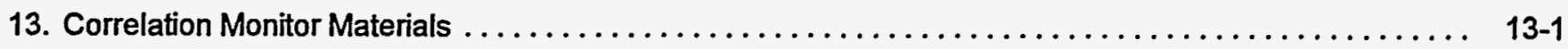

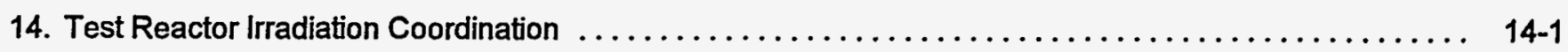

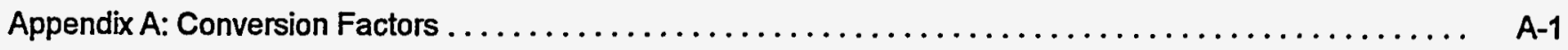




\section{List of Figures}

Page

2.1 Unirradiated and irradiated crack-arrest toughness for the ANPA A 508 class 3 forging material showing the relationships between the unirradiated and irradiated data $\ldots \ldots \ldots \ldots \ldots$.

4.1 Master curve and $5 \%$ confidence limit curve (dashed) adjusted $10^{\circ} \mathrm{C}\left(18^{\circ} \mathrm{F}\right)$ for uncertainty

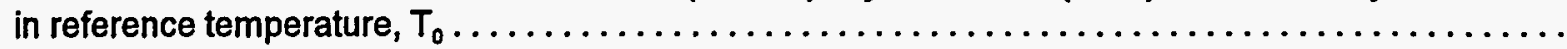

4.2 Transition temperature data for the Midland nozzle course weld WF-70 for two compact specimen sizes and a master curve on $1 \mathrm{~T}$ specimen size

4.3 J-R curves that compare the nozzle versus the beltline weld metal ductile tearing resistance

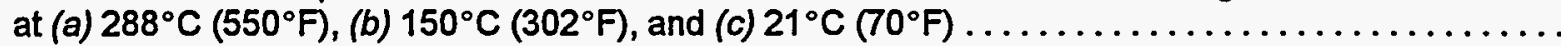

4.4 Master curve from specimens of capsule 10.05. All data were normalized to 1TC (T) equivalence

4.5 $\quad \mathrm{K}_{\mathrm{Jc}}$ data on unirradiated Midland beltline weld metal. Four precracked Charpy specimens (dashed squares) gave invalid $\mathrm{K}_{\mathrm{Jc}}$ values

4.6 $\mathrm{K}_{\mathrm{Jc}}$ data on irradiated Midland beltline weld metal. Four precracked Charpy specimens

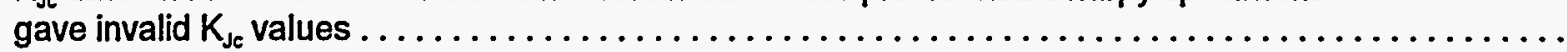

4.7 Crack-arrest toughness, $K_{2}$, of specimens machined from submerged-arc welds of Midland reactor pressure vessels, as well as a mean and lower-bound toughness curve (specimens are oriented so that crack propagation is in the welding direction)

4.8 Crack-arrest toughness, $K_{2}$, of specimens machined from submerged-arc welds of Midland reactor pressure vessels, showing a mean, lower-bound, and two bounding ASME $K_{12}$ curves .......

4.9 Percent change of $K_{2}$ due to the proposed change in the present ASTME 1221 as a function

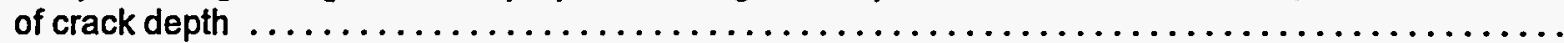

6.1 Dosimetry verification capsule for the East and South side facilities of the University of

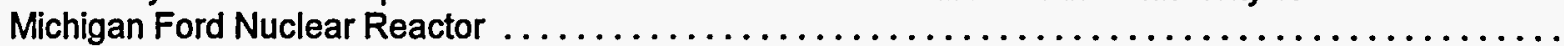

7.1 Evolution of matrix copper content in a commercial weld at various stages of heat treatment, irradiation, and following postirradiation annealing

7.2 Comparison of hardness change measured in various ion-irradiated and aged steels by nanoindenter and 200-g Vickers; indentation depths for the nanohardness data $\left(H_{N}\right)$ are

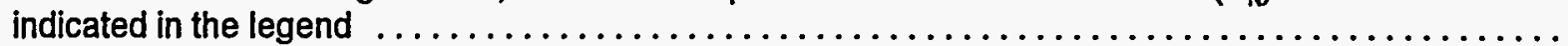

10.1 Comparison of irradiation-induced temperature shifts for reactor pressure vessel plate steels determined from fracture toughness and Charpy V-notch impact tests at $100 \mathrm{MPa} \sqrt{\mathrm{m}}$ and $41 \mathrm{~J}$, respectively

10.2 Comparison of irradiation-induced temperature shifts for reactor pressure vessel forging steels determined from fracture toughness and Charpy V-notch impact tests at $100 \mathrm{MPa} \sqrt{\mathrm{m}}$ and $41 \mathrm{~J}$, respectively

10.3 Comparison of irradiation-induced temperature shifts for reactor pressure vessel welds determined from fracture toughness and Charpy $\mathrm{V}$-notch impact tests at $100 \mathrm{MPa} \sqrt{\mathrm{m}}$ and $41 \mathrm{~J}$, respectively 
10.4 Comparison of irradiation-induced temperature shifts for reactor pressure vessel steels (plates, forgings, and welds) determined from fracture toughness and Charpy V-notch impact tests at $100 \mathrm{MPa} \sqrt{\mathrm{m}}$ and $41 \mathrm{~J}$, respectively.

11.1 Developed view of the Pressure Vessel Research Users Facility vessel located near Building K-702 at the K-25 site

11.2 Variation of Charpy impact upper-shelf energy of 26 separate data sets from the Midland WF-70 material

\section{List of Tables}

2.1 Chemical composition of the A 508 class 3 forging used by ANPA to machine

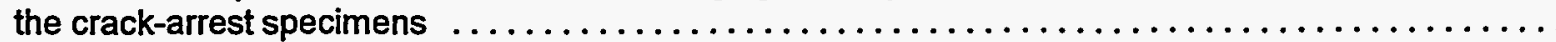

2.2 The range of crack-irradiation toughness, $K_{J c}$, for the 1TC $(T)$ specimens exhibited in the Fifth Irradiation Series

2.3 Test plan for weld $73 \mathrm{~W}$ high-fluence capsule

2.4 Proposed irradiated specimen complement for the high-fluence capsule

3.1 Results of chemical analysis through the thickness of weld $2 A$ using weld wire L-TEC 44, heat 44112 , and Linde 80 flux [hydrogen baked at $204.4^{\circ} \mathrm{C}\left(400^{\circ} \mathrm{F}\right)$ for $8 \mathrm{~h}$ ]

3.2 Comparison of chemical composition of weld $73 \mathrm{~W}$ (Linde 124 flux) and welds 1, 2A, and 3 fabricated with weld wire L-TEC, heat 44112, and Linde 80 flux

3.3 Test plans for three low upper-shelf welds fabricated with Linde 80 flux

4.1 Reference and transition temperature shifts for Midland WF-70 beltline weld

4.2 Crack-arrest toughness, $K_{2}$ of Midland WF-70 submerged-arc weld metal specimens (specimens are oriented so that crack propagation is in the welding direction)

9.1 Average and one standard deviation values of absorbed energy, lateral expansion, and shear fracture of HSST plate 13A tested at ORNL.

9.2 Average and one standard deviation values of absorbed energy, lateral expansion, and shear fracture of JPDR Poison Tank Material tested at ORNL $\ldots \ldots \ldots \ldots \ldots \ldots \ldots \ldots \ldots \ldots \ldots$

11.1 Specimen complement in terms of the number and size of precracked Charpy, tensile, 1TC (T), and drop-weight specimens for each of the four azimuthal locations 


\section{Acknowledgments}

The authors thank Julia Bishop for her contributions in the preparation of the draft manuscript for this report, Analysas Corporation for the final manuscript preparation, and K. Spence for editing and quality assurance review. The authors also gratefully acknowledge the continuing technical and financial contributions of the Nuclear Regulatory Commission to the Heavy-Section Steel Irradiation Program. 


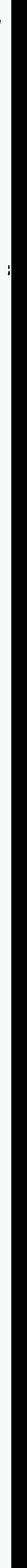




\section{Preface}

The primary goal of the Heavy-Section Steel Irradiation (HSSI) Program is to provide a thorough, quantitative assessment of the effects of neutron irradiation on the material behavior and, in particular, the fracture toughness properties of typical pressure-vessel steels as they relate to light-water reactor pressure vessel (RPV) integrity. The program includes studies of the effects of irradiation on the degradation of mechanical and fracture properties of vessel materials augmented by enhanced examinations and modeling of the accompanying microstructural changes. Effects of specimen size; material chemistry; product form and microstructure; irradiation fluence, flux, temperature, and spectrum; and postirradiation annealing are being examined on a wide range of fracture properties. Results from the HSSI studies will be incorporated into codes and standards directly applicable to resolving major regulatory issues which involve RPV irradiation embrittlement such as pressurized-thermal shock, operating pressure-temperature limits, low-temperature overpressurization, and the specialized problems associated with low upper-shelf welds.

This HSSI Program progress report covers work performed from April 1995 to September 1995. The work performed by Oak Ridge National Laboratory (ORNL) is managed by the Metals and Ceramics (M\&C) Division of ORNL. Major tasks at ORNL are carried out by the M\&C, Computing Physics and Engineering, and Engineering Technology Divisions.

Previous HSSI Progress Reports in this series are:

NUREG/CR-5591, Vol. 1, No. 1 (ORNLTM-11568N1\&N1)

NUREG/CR-5591, Vol. 1, No. 2 (ORNL/TM-11568N1\&N2)

NUREG/CR-5591, Vol. 2, No. 1 (ORNL/TM-11568N2\&N1)

NUREG/CR-5591, Vol. 2, No. 2 (ORNLTM-11568N2\&N2)

NUREG/CR-5591, Vol. 3 (ORNLTM-11568N3)

NUREG/CR-5591, Vol. 4, No. 1 (ORNL/TM-11568N4\&N1)

NUREG/CR-5591, Vol. 4, No. 2 (ORNL/TM-11568N4\&N2)

NUREG/CR-5591, Vol. 5, No. 1 (ORNL/TM-11568N5\&N1)

NUREG/CR-5591, Vol. 5, No. 2 (ORNL/TM-11568N5\&N2)

NUREG/CR-5591, Vol. 6, No. 1 (ORNL/TM-11568N6\&N1)

Some of the series of irradiation studies conducted within the HSSI Program were begun under the Heavy-Section Steel Technology (HSST) Program prior to the separation of the two programs in 1989. Previous HSST Program progress reports contain much information on the irradiation assessments being continued by the HSSI Program as well as earlier related studies. The HSST Program progress reports issued before formation of the HSSI Program are also tabulated here as a convenience to the reader.

ORNL-4176

ORNL-4315

ORNL-4377

ORNL-4463

ORNL-4512

ORNL-4590

ORNL-4653 
ORNL-4681

ORNL-4764

ORNL-4816

ORNL-4855

ORNL-4918

ORNL-4971

ORNLTM-4655 (Vol. II)

ORNLTM-4729 (Vol. II)

ORNL/TM-4805 (Vol. II)

ORNL/TM-4914 (Vol. II)

ORNLTM-5021 (Nol. II)

ORNLTM-5170

ORNL/NUREG/TM-3

ORNL/NUREG/TM-28

ORNL/NUREG/TM-49

ORNLNNUREG/TM-64

ORNL/NUREG/TM-94

ORNL/NUREG/TM-120

ORNL/NUREG/TM-147

ORNL/NUREG/TM-166

ORNLNUREG/TM-194

ORNLNUREG/TM-209

ORNL/NUREG/TM-239

NUREG/CR-0476 (ORNLNUREG/TM-275)

NUREG/CR-0656 (ORNLNUREG/TM-298)

NUREG/CR-0818 (ORNL/NUREG/TM-324)

NUREG/CR-0980 (ORNL/NUREG/TM-347)

NUREG/CR-1197 (ORNL/NUREG/TM-370)

NUREG/CR-1305 (ORNL/NUREG/TM-380)

NUREG/CR-1477 (ORNL/NUREG/TM-393)

NUREG/CR-1627 (ORNL/NUREG/TM-401)

NUREG/CR-1806 (ORNL/NUREG/TM-419)

NUREG/CR-1941 (ORNL/NUREG/TM-437)

NUREG/CR-2141, Vol. 1 (ORNL/TM-7822)

NUREG/CR-2141, Vol. 2 (ORNL/TM-7955)

NUREG/CR-2141, Vol. 3 (ORNLTM-8145)

NUREG/CR-2141, Vol. 4 (ORNL/TM-8252)

NUREG/CR-2751, Vol. 1 (ORNUTM-8369N1)

NUREG/CR-2751, Vol. 2 (ORNL/TM-8369N2)

NUREG/CR-2751, Vol. 3 (ORNL/TM-8369N3)

NUREG/CR-2751, Vol. 4 (ORNLTM-8369N4)

NUREG/CR-3334, Vol. 1 (ORNUTM-8787N1)

NUREG/CR-3334, Vol. 2 (ORNLTM-8787N2)

NUREG/CR-3334, Vol. 3 (ORNLTM-8787N3)

NUREG/CR-3744, Vol. 1 (ORNLTM-9154N1)

NUREG/CR-3744, Vol. 2 (ORNLTM-9154N2)

NUREG/CR-4219, Vol. 1 (ORNLTM-9593N1)

NUREG/CR-4219, Vol. 2 (ORNLTM-9593N2)

NUREG/CR-4219, Vol. 3, No. 1 (ORNLTM-9593N3\&N1)

NUREG/CR-4219, Vol. 3, No. 2 (ORNLTM-9593N3\&N2)

NUREG/CR-4219, Vol. 4, No. 1 (ORNLTM-9593N4\&N1)

NUREG/CR-4219, Vol. 4, No. 2 (ORNLTM-9593N4\&N2)

NUREG/CR-4219, Vol. 5, No. 1 (ORNLTM-9593N5\&N1)

NUREG/CR-4219, Vol. 5, No. 2 (ORNLTM-9593N5\&N2) 


\section{Summary}

\section{Program Management}

The Heavy-Section Steel Irradiation (HSSI) Program is arranged into 14 tasks: (1) program management, (2) fracture toughness curve shifts in high-copper weldments (Series 5 and 6), (3) $K_{c}$ and $K_{t a}$ curve shifts in low upper-shelf (LUS) welds (Series 8), (4) irradiation effects in a commercial LUS weld (Series 10), (5) irradiation effects on weld heat-affected zone (HAZ) and plate materials (Series 11), (6) annealing effects in LUS welds (Series 9), (7) microstructural analysis of irradiation effects, (8) in-service irradiated and aged material evaluations, (9) Japan Power Development Reactor (JPDR) pressure-vessel steel examination, (10) fracture toughness curve shift method, (11) special technical assistance, (12) technical assistance for Joint Coordinating Committee on Civilian Nuclear Reactor Safety (JCCCNRS) Working Groups 3 and 12, (13) correlation monitor materials, and (14) test reactor irradiation coordination. Report chapters correspond to the tasks. The work is performed by the Oak Ridge National Laboratory (ORNL). During the report period, 17 program briefings, reviews, or presentations were made by the HSSI staff during program reviews and visits with Nuclear Regulatory Commission (NRC) staff or others. Twelve technical papers, two letter reports, and one foreign trip report were published. In addition, 43 technical presentations were made.

\section{Fracture Toughness Shifts in High-Copper Weldments (Series $\mathbf{5}$ and 6)}

The objective of this task is to develop data addressing the current method of shifting the American Society of Mechanical Engineers (ASME) fracture-toughness $\left(K_{\mathrm{le}}, K_{\mathrm{la}}\right.$, and $\left.K_{\mathrm{lR}}\right)$ curves to account for irradiation embrittlement in high-copper welds. The specific activities to be performed in this task are: (1) continuation of Phase 2 of the Fifth Irradiation Series and (2) completion of the Sixth Irradiation Series, including testing nine irradiated Italian crackarrest specimens. The results of testing the ltalian crack-arrest specimens have been analyzed, a draft NUREG report has been prepared, and the reviewers' comments are being incorporated. A better method for calculating the force needed to adjust the crack-mouth opening displacement has been implemented, and the final crackarrest toughness of the Italian specimens is presented. As part of this task, irradiation of HSSI weld 73W to a high fluence $\left[5 \times 10^{19}\right.$ neutrons $\left./ \mathrm{cm}^{2}(>1 \mathrm{MeV})\right]$ will be performed to determine whether the $\mathrm{K}_{\mathrm{Jc}}$ curve shape change observed in the Fifth Series is exacerbated. A test plan that has been developed is presented, and specimen fabrication will begin shortly. The design and fabrication of the temperature and dosimetry verification capsules are performed under this task, but for purposes of continuity, their progress will be reported under Task 6 , where the design of the new irradiation facilities and capsules is performed.

\section{Fracture Toughness Curve Shifts in Low Upper-Shelf Welds (Series 8)}

This task examines the fracture toughness curve shifts and changes in shape for irradiated welds with low Charpy V-notch (CVN) upper-shelf energy (USE). This task was specifically designed to address questions raised by the Advisory Committee for Reactor Safeguards concerning the shape of the $K_{1 c}$ curve for irradiated welds with a low USE. In particular, it will clarify whether the high concentration of inclusions in low-USE welds results in a transition relationship and behavior significantly different from high-USE welds. The information developed under this task will augment information obtained from other HSSI tasks performed on two high-USE weldments under the Fifth and Sixth Irradiation Series and on a commercial, low USE under the Tenth Irradiation Series. The results will provide an expanded basis for accounting for irradiation-induced embrittlement in reactor pressure vessel (RPV) materials.

To provide material for this and for the annealing task (HSSI Series 9), three trial low-USE welds were ordered from ABB-Combustion Engineering (ABB-CE), Chattanooga, Tennessee, who had also fabricated the welds for the Fifth and Sixth Series. Two of the three welds previously received included chemical and mechanical properties obtained by ABB-CE and have been reported in the previous semiannual. The third weld has now been received, and the current status and test plans for all three welds will be presented here. 


\section{Irradiation Effects in a Commercial Low Upper-Shelf Weld (Series 10)}

The objective of this task is to evaluate the chemical, mechanical, and fracture properties of the WF-70 weld metal at the beltline and nozzle course locations in the Midland Unit 1 reactor vessel before and after irradiation. Fracture toughness tests of unirradiated beltline and nozzle course welds have shown a transition temperature of the nozzle course weld about $20^{\circ} \mathrm{C}$ higher than that of the beltline weld; the J-R curves of the nozzle course weld are also lower than those of the beltline weld. Testing of specimens from two scoping capsules (capsules 10.01 and 10.02) at $0.5 \times 10^{19}$ neutrons $/ \mathrm{cm}^{2}\left(>1 \mathrm{MeV}\right.$ ) and from the first large capsule (capsule 10.05) at $1.0 \times 10^{19}$ neutrons $/ \mathrm{cm}^{2}$ $(>1 \mathrm{MeV}$ ) has been completed and the results reported in ORNLNRC/LTR-95/18. For the beltline weld, comparison of the irradiation-induced Charpy $41-\mathrm{J}$ and fracture toughness $100-\mathrm{MPa} \sqrt{\mathrm{m}}$ shifts shows mixed results. At $0.5 \times 10^{19}$ neutrons $/ \mathrm{cm}^{2}$, the fracture toughness shift exceeded the Charpy shift by $24^{\circ} \mathrm{C}$, whereas, at $1.0 \times 10^{19}$ neutrons $/ \mathrm{cm}^{2}$, the Charpy shift exceeded the fracture toughness shift by $17^{\circ} \mathrm{C}$. Precracked Charpy specimens of beltline weld were also tested in the unirradiated and irradiated conditions and showed an irradiationinduced fracture toughness shift very close to that indicated by the compact specimens. Crack-arrest testing has also been performed with the unirradiated beltline weld. Relative to the $\mathrm{RT}_{\mathrm{NDT}}$, the crack-arrest toughness results are similar to the fracture toughness results in that use of the $\mathrm{RT}_{\mathrm{NDT}}$ for indexing the crack-arrest toughness curve provides a very conservative result. Irradiation of capsule 10.06 was completed, the capsule has been shipped to ORNL and disassembled, and the specimens are awaiting testing in the hot cell.

\section{Irradiation Effects on Weld Heat-Affected Zone and Plate Materials (Series 11)}

The purpose of this task is to examine the effects of neutron irradiation on the fracture toughness (ductile and brittle) of the HAZ of welds of $A 302$ grade $B(A 302 B$ ) plate materials typical of those used in fabricating older RPVs. The initial plate material of emphasis will be A302B steel, not the A302B modified with nickel additions. Two specific plates, previously identified as being applicable to this task, have been requested from Yankee Atomic Electric Company (YAEC) for use in this irradiation task. YAEC has agreed to provide the materials, and shipping to ORNL is under way.

\section{Annealing Effects in Low Upper-Shelf. Welds (Series 9)}

The purpose of the Ninth Irradiation Series is to evaluate the correlation between fracture toughness and CVN impact energy during irradiation, annealing, and reirradiation (IAR). The activities in this reporting period have concentrated on the preparation of equipment and components necessary for in situ IAR at two locations on the East side of the University of Michigan Ford Nuclear Reactor. The facilities consist of equipment to hold the capsules containing the specimens to be irradiated to maintain uniform and constant temperatures during irradiation, as well as to anneal the specimens. Before capsule irradiation can begin, dosimetry and temperature verification tests must be completed. The design of a reusable capsule capable of reirradiating IAR CVN and ITC (T) specimens is also progressing. The data acquisition and control system for the first two IAR facilities is complete and awaiting completion of the IAR facilities and temperature test capsule for checkout and control algorithm development.

\section{Microstructural Analysis of Irradiation Effects}

The overall long-term goal of this task is to develop a physically based model which can be used to predict irradiation-induced embrittlement in reactor vessel steels over the full range of their service conditions. The model should be tethered soundly on the microstructural level by results from advanced microstructural analysis techniques and constrained at the macroscopic level to produce predictions consistent with the large array of macroscopic embrittlement measurements that are available. During this reporting period, microstructural characterizations of long-term $(\sim 100,000 \mathrm{~h})$ thermally aged, neutron-irradiated, and annealed surveillance materials were completed. An atom-probe field-ion microscopy characterization of a thermally aged Fe-1.28 wt \% Cu-1.43 wt \% Ni model alloy has been performed to investigate the suitability of these simple alloys as models for 
commercial RPV steels. The validity of the low-load "nanoindentation" technique to monitor strength changes was established using a range of commercial and model materials. A comparison of model predictions and available data seemed to confirm that the lead factors commonly employed in commercial surveillance programs should have negligible impact on the validity of the data obtained.

\section{In-Service Irradiated and Aged Material Evaluations}

The objective of this task is to provide a direct assessment of actual material properties in irradiated components of nuclear reactors, including the effects of irradiation and aging. Four activities are currently in progress:

(1) establishing a machining capability for contaminated or activated materials by completing procurement and installation of a computer-based milling machine in a hot cell, (2) machining and testing specimens from cladding materials removed from the Gundremmingen reactor to establish their fracture properties, (3) preparing an interpretive report on the effects of neutron irradiation on cladding, and (4) continuing the evaluation of long-term aging at low temperatures of austenitic structural stainless steel weld metal.

Modification of the computer numerically controlled (CNC) machining center is in progress. Several items have been completed, including drawings, new cables and table, machine enclosure, fittings, and a floor tub for installation inside the hot cell. Additionally, a new saw was purchased for slicing specimens into suitable sizes for machining on the CNC machine. Tensile and CVN impact tests of type 308 stainless steil weld metals aged at $343^{\circ} \mathrm{C}$ for up to $50,000 \mathrm{~h}$ showed that aging had little effect on the tensile properties, but did result in embrittlement as shown by the impact testing. Aging of three-wire cladding at $288^{\circ} \mathrm{C}$ for $50,000 \mathrm{~h}$ and greater is continuing to better quantify the effects of long-term thermal aging on cladding.

\section{JPDR Pressure-Vessel Steel Examination}

There is a need to validate the results of irradiation effects research by the examination of material taken directly from the wall of a pressure vessel which has been irradiated during normal service. This task has been included with the HSSI Program to provide just such an evaluation on material from the wall of the pressure vessel from the JPDR. During this reporting period, the baseline testing for the cross comparison of the effects of the different tups used in U.S. and Japanese Charpy impact machines was performed to provide a basis for understanding any differences that might later arise from testing of the JPDR materials.

\section{Fracture Toughness Curve Shift Method}

The purpose of this task is to examine the technical basis for the currently accepted methods for shifting fracture toughness curves to account for irradiation damage, and to work through national codes and standards bodies to revise those methods, if a change is warranted. Specific activities under this task include: (1) collection and statistical analysis of pertinent fracture toughness data to assess the shift and potential change in shape of the fracture toughness curves due to neutron irradiation, thermal aging, or both; (2) evaluation of methods for indexing fracture toughness curves to values that can be deduced from material surveillance programs required under the Code of Federal Regulations (10CFR50), Appendix H; (3) participation in the pertinent ASME Section XI, American Society for Testing and Materials (ASTM) E-8, and ASTM E-10 committees; (4) interaction with other researchers in the national and international technical community addressing similar problems; and (5) frequent interactions and detailed technical meetings with the NRC staff.

During this reporting period, data from the published literature were acquired, and a preliminary analysis was performed. In this preliminary analysis, the raw data were not analyzed by ORNL; rather, the irradiation-induced shifts reported by the authors were used. Data were obtained for plates, forgings, and welds. On average, the fracture toughness shifts generally exceeded the Charpy $41-J$ shifts by about 20,50 , and $8 \%$ for plates, forgings, and welds, respectively. Overall, the fracture toughness shifts exceed the CVN shifts by about $14 \%$, about the same result reported previously from analysis of HSSI Program data. 


\section{Special Technical Assistance}

This task has been included with the HSSI Program to provide a vehicle by which to conduct and monitor shortterm, high-priority subtasks and provide technical expertise and assistance in the review of national codes and standards that may be referenced in NRC regulations or guides related to nuclear reactor components. This task currently addresses two major areas: (1) providing technical expertise and assistance in the review of national codes and standards and (2) experimental evaluations of test specimens and practices and material properties. The following activities occurred during this reporting period.

Evaluation of the precracked cylindrical tensile specimen is continuing. A report by SRI International was received and is being prepared as a NUREG/ORNL-Sub report. A preliminary report has been prepared by AEA Technology, Harwell, United Kingdom, regarding their test results and will be reviewed by ORNL prior to final publication. A detailed plan has been developed for removal of material from the pressurized-water RPV, the Pressure Vessel Research User's Facility located at the Oak Ridge Gaseous Diffusion Plant (K-25 site). Material will be removed for experimental projects within the HSSI and Heavy-Section Steel Technology (HSST) Programs at ORNL, as well as the Nondestructive Evaluation Program at Pacific Northwest Laboratory.

\section{Technical Assistance for JCCCNRS Working Groups 3 and 12}

The purpose of this task is to provide technical support for the efforts of the U.S.-Russian JCCCNRS Working Group 3 on radiation embrittlement and Working Group 12 on aging. Specific activities under this task are:

(1) supply of materials and preparation of test specimens for collaborative IAR studies to be conducted in Russia;

(2) capsule preparation and initiation of irradiation of Russian specimens within the United States; (3) preparation for and participation in Working Groups 3 and 12 meetings; and (4) sponsoring of the assignment at ORNL of a scientist from the Russian National Research Center, Kurchatov Institute.

The sabbatical of Dr. Mikhail A. Sokolov at ORNL continued. The results of his research are presented within the particular technical tasks of HSSI semiannual progress reports and published technical reports and papers. The CVN and round tensile specimens of two Russian weld metals irradiated in HSSI capsule 10.06 were returned to ORNL. The capsule has been disassembled, specimens identified, and the specimens of Russian steels have been transferred from the disassembly hot cells to the testing hot cells. Testing is anticipated to be completed prior to the end of 1995, depending on funding and the scheduling of the next JCCCNRS Working Group 3 meeting.

\section{Correlation Monitor Materials}

This is a task that has been established with the explicit purpose of ensuring the continued availability of the pedigreed and extremely well-characterized material now required for inclusion in all additional and future surveillance capsules in commercial light-water reactors. Having recognized that the only remaining materials qualified for use as a correlation monitor in reactor surveillance capsules are the pieces remaining from the early HSST plates 01,02 , and 03 , this task will provide for cataloging, archiving, and distributing the material on behalf of the NRC. During this reporting period, the remaining correlation monitor materials were moved from the storage area at the Y-12 Plant and placed into the HSSI storage facility at the ORNL site. Two blocks of HSST plate 03 were sent to the Hanjung America Corp. for use as correlation monitor materials in Units 3 and 4 of the Ulchin Nuclear Power Plant in Korea. A detailed reinventory of the correlation monitor materials was initiated after their transfer from the Y-12 Plant to the archival storage location at ORNL. Minor discrepancies between what was anticipated and what was found led to the realization that a small amount of the material still remained at $Y-12$. Preparations were made to transfer the residual material to ORNL. 


\section{Test Reactor Irradiation Coordination}

The purpose of this task is to provide the support required to supply and coordinate irradiation senices needed by NRC contractors other than ORNL. These services include the design and assembly of irradiation capsules as well as arranging for their exposure, disassembly, and return of specimens. Currently, the University of California, Santa Barbara, is the only other NRC contractor for whom irradiations are to be conducted. During this reporting period, the engineering drawings for most of the facility were completed. Procurement and fabrication of selected portions of the facility were initiated. 


\title{
Heavy-Section Steel Irradiation Program Semiannual Progress Report for April 1995 through September 1995,
}

\author{
W. R. Corwin
}

\section{Program Management}

The Heavy-Section Steel Irradiation (HSSI) Program, a major safety program sponsored by the Nuclear Regulatory Commission (NRC) at Oak Ridge National Laboratory (ORNL), is an engineering research activity devoted to providing a thorough, quantitative assessment of the effects of neutron irradiation on the material behavior, particularly the fracture toughness properties, of typical pressure-vessel steels as they relate to light-water reactor pressure vessel (RPV) integrity. The program centers on experimental assessments of irradiation-induced embrittlement augmented by detailed examinations and modeling of the accompanying microstructural changes. Effects of specimen size; material chemistry; product form and microstructure; irradiation fluence, flux, temperature, and spectrum; and postirradiation annealing are being examined on a wide range of fracture properties. Fracture toughness $\left(K_{1 c}\right.$ and $\left.J_{1 c}\right)$, crack-arrest toughness $\left(K_{t_{2}}\right)$, ductile tearing resistance (dJ/da), Charpy V-notch (CVN) impact energy, drop-weight (DWT) nil-ductility transition (NDT), and tensile properties are included. Models based on observations of radiation-induced microstructural changes using the atom-probe field-ion microscope (APFIM) and the high-resolution transmission electron microscope (TEM) are being developed to provide a firm basis for extrapolating the measured changes in fracture properties to wide ranges of irradiation conditions. The principal materials examined within the HSSI Program are high-copper welds because their postirradiation properties frequently limit the continued safe operation of commercial RPVs. In addition, a limited effort will focus on stainless steel weld-overlay cladding typical of that used on the inner surfaces of RPVs because its postirradiation fracture properties have the potential for strongly affecting the extension of small surface flaws during overcooling transients.

Results from the HSSI studies will be integrated to aid in resolving major regulatory issues facing the NRC. Those issues involve RPV irradiation embrittlement such as pressurized-thermal shock, operating pressure-temperature limits, low-temperature overpressurization, and the specialized problems associated with low upper-shelf (LUS) welds. Together, the results of these studies also provide guidance and bases for evaluating the overall aging behavior of light-water RPVs.

The program is coordinated with those of other government agencies and the manufacturing and utility sectors of the nuclear power industry in the United States and abroad. The overall objective is the quantification of irradiation effects for safety assessments of regulatory agencies, professional code-writing bodies, and the nuclear power industry.

The program is broken down into 1 task responsible for overall program management and 13 technical tasks: (1) program management, (2) fracture toughness curve shifts in high-copper weldments (Series 5 and 6 ), (3) $K_{1 c}$ and $K_{12}$ curve shifts in LUS welds (Series 8), (4) irradiation effects in a commercial LUS weld (Series 10), (5) irradiation effects on weld heat-affected zone (HAZ) and plate materials (Series 11), (6) annealing effects in LUS welds (Series 9), (7) microstructural analysis of irradiation effects, (8) in-service irradiated and aged material evaluations, (9) Japan Power Development Reactor (JPDR) pressure-vessel steel examination, (10) fracture "Research sponsored by the Office of Nuclear Regulatory Research, U.S. Nuclear Regulatory Commission, under Interagency Agreement
DOE 1886-8109-8L with the U.S. Department of Energy under contract with Lockheed Martin Energy Research Corp.

TThe submitted manuscript has been authored by a contractor of the U.S. Government under contract DE-AC05-960R22464. Accordingly, the U.S. Government retains a non-exclusive, royalty-free license to publish or reproduce the published form of this contribution, or allow others to do so, for U.S. Government purposes. 
toughness curve shift method, (11) special technical assistance, (12) technical assistance for Joint Coordinating Committee on Civilian Nuclear Reactor Safety (JCCCNRS) Working Groups 3 and 12, (13) correlation monitor materials, and (14) test reactor irradiation coordination.

During this period, 17 program briefings, reviews, or presentations were made by the HSSI staff during program reviews and visits with NRC staff or others. Twelve technical papers, ${ }^{1-12}$ two letter reports, ${ }^{13-14}$ and one foreign trip report's ${ }^{15}$ ere published. In addition, 43 technical presentations were made. ${ }^{16-58}$

\section{References}

1. W. R. Corwin, Martin Marietta Energy Systems, Inc., Oak Ridge Natl. Lab., Semiannual Progress Report for April 1991 - September 1991, USNRC Report, NUREG/CR-5591, Vol. 2, No. 2 (ORNLTM11568N2\&N2), October 1994."

2. W. R. Conwin, Martin Marietta Energy Systems, Inc., Oak Ridge Natl. Lab., Semiannual Progress Report for October 1991 - September 1992, USNRC Report, NUREG/CR-5591, Vol. 3 (ORNLTM-11568N3), February 1995."

3. W. R. Corwin, Lockheed Martin Energy Systems, Inc., Oak Ridge Natl. Lab., Semiannual Progress Report for September 1993 - March 1994, USNRC Report, NUREG/CR-5591, Vol. 5, No. 1 (ORNLTM11568N5\&N1), April 1994.*

4. W. R. Corwin, Lockheed Martin Energy Systems, Inc., Oak Ridge Natl. Lab., Semiannual Progress Report for April 1993 - September 1994, USNRC Report, NUREG/CR-5591, Vol. 5, No. 2 (ORNL/MM11568N5\&N2), July 1994.*

5. W. R. Corwin and W. E. Pennell, "Reactor Pressure Vessel Structural Integrity Research," pp. 17-32 in Proceedings of the Twenty-Second Water Reactor Safety Information Meeting, USNRC Report, NUREG/CP-0140, Vol. 3, April 1995.*

6. P. P. Milella, A. Pini, S. K. Iskander, C. W. Marschall, and A. R. Rosenfield, "Effects of Radiation on Crack-Initiation and Crack-Arrest Toughness for SA508 Cl. 3 Steel," pp. 237-42 in Fatigue and Fracture Mechanics in Pressure Vessels and Piping, PVP-Vol. 304, H. S. Mehta, Ed., American Society of Mechanical Engineers, New York, 1995.†

7. R. K. Nanstad, W. R. Corwin, D. J. Alexander, F. M. Haggag, S. K. Iskander, D. E. McCabe, M. A. Sokolov, and R. E. Stoller, "Heavy-Section Steel Irradiation Program on Irradiation Effects in LightWater Reactor Pressure Vessel Materials," pp. 297-310 in Fatigue and Crack Growth: Environmental Effects, Modeling Studies, and Design Considerations, PVP-Vol. 306, S. Yukawa, Ed., American Society of Mechanical Engineers, New York, 1995.†

8. W. R. Corwin and W. E. Pennell, "Reactor Pressure Vessel Structural Integrity Research," pp. 159-76 in Nucl. Eng. Des. 157, 159-176 (1995).†

9. W. R. Corwin, R. K. Nanstad, D. J. Alexander, G. R. Odette, R. E. Stoller, and J. A. Wang, "Thermal Embrittlement of Reactor Vessel Steels, " pp. 345-50 in Transactions of the 13th International Conference on Structural Mechanics in Reactor Technology (SMiRT 13), Port Alegre, Brazil, August 13-18, 1995.†

10. M. K. Miller, K. F. Russell, and R. Jayaram, "Characterization of Phosphorus Segregation in Neutronirradated Russian Pressure Vessel Steel Weld," Nucl. Mater. 225, 215-24 (1995).†

\footnotetext{
"Available for purchase from National Technical Information Service, Springfield, VA 22161.

†Available in public technical libraries.
} 
11. M. K. Miller, K. F. Russell, A. Jostsons, and R. G. Blake, "Characterization of Neutron-irradiated Fe-Au Alloys," Appl. Surf. Sci. 87/88, 216-22 (1995). †

12. M. K. Miller, R. Jayaram, and K. F. Russell, "Characterization of Phosphorus Segregation in NeutronIrradiated Pressure Vessel Steels by Atom-Probe Field-lon Microscopy, ${ }^{n}$ pp. 113-18 in Microstructure of Iradiated Materials, Proceedings of Materials Research Society Fall Meeting, Boston, Massachusetts, November 28-December 1, 1994, Vol. 373, I. M. Robertson, L. E. Rehn, S. Z. Zinkle, and W. J. Pythian, Eds., Materials Research Society, Pittsburgh, 1995. $\dagger$

13. M. A. Sokolov and D. E. McCabe, Lockheed Martin Energy Systems, Inc., Oak Ridge Natl. Lab., Comparison of Irradiation-induced Shifts of $K_{s t}$ and Charpy Curves: Analysis of Heavy-Section Steel Irradiation Program Data, ORNLNRCRTR-95/4, July 1995.

14. D. E. McCabe, M. A. Sokolov, R. K. Nanstad, and R. L. Swain, Lockheed Martin Energy Systems, Inc., Oak Ridge Natl. Lab., Effects of Irradiation to 0.5 and $1.0 \times 10^{19}$ neutrons $/ \mathrm{cm}^{2}(>1 \mathrm{MeV}$ on the Midland Reactor Low Upper-Shelf Weld: Capsules 10.01, 10.02, and 10.05 in the Heavy-Section Steel Irradiation Program Tenth Irradiation Series, ORNLNRC/LTR-95/18, August 1995.

15. R. K. Nanstad, Report of Foreign Travel to Czech Republic, Belgium, France, and United Kingdom, ORNLFTR-5372 (September 1995).

16. M. A. Sokolov, "Subsize Impact Specimer, Studies," presented at the ASTM E28.07.08 Committee Meeting, Denver, Colorado, May 15, 1995.

17. D. E. McCabe, H. A. Ernst, and J. C. Newman, Jr., "Application of Elastic and Elastic-Plastic Fracture Mechanics Methods to Surface Flaws," presented at the ASTM Workshop on Fracture Behavior of Surface Cracks, Denver, Colorado, May 15, 1995.

18. D. E. McCabe, "Discussion of Items Changed in the Ninth Draft of the Test Practice," presented to ASTM Task Group E08.08.03, Denver, Colorado, May 15, 1995.

19. R. K. Nanstad, S. K. Iskander, M. A. Sokolov, and D. E. McCabe, "Fracture Toughness Curve Shift Studies, Heavy-Section Steel Irradiation Program," presented at NRI, Prague, Czech Republic, May 22, 1995.

20. R. K. Nanstad, S. K. Iskander, M. A. Sokolov, and D. E. McCabe, "Fracture Toughness Curve Shift Studies, Heavy-Section Steel Irradiation Program," presented at SCK-CEN, Mol, Belgium, May 25, 1995.

21. R. K. Nanstad, S. K. Iskander, M. A. Sokolov, and D. E. McCabe, "Fracture Toughness Curve Shift Studies, Heavy-Section Steel Irradiation Program," presented at Framatome/EDF, Paris, France, May 29, 1995.

22. R. K. Nanstad, S. K. Iskander, M. A. Sokolov, and D. E. McCabe, "Fracture Toughness Curve Shift Studies, Heavy-Section Steel Irradiation Program," presented at Rolls-Royce Associates, Derby, United Kingdom, May 31, 1995.

23. R. K. Nanstad and G. Gage, "Preliminary Observations from Results of ASTM Round-Robin on Reconstituted CVN," presented at the ASTM Committee E10 Meeting, Denver, Colorado, June 19, 1995.

24. R. K. Nanstad, D. E. McCabe, M. A. Sokolov, and G. Gage, "Fracture Toughness Results from Precracked Charpy Specimens," presented at the ASTM Committee E10 Meeting, Denver, Colorado, June 19, 1995.

\footnotetext{
"Available for purchase from National Technical Information Service, Springfield, VA 22161. †Avallable in public technical libraries.
} 
25. P. J. Pareige, M. K. Miller, and R. E. Stoller, "Microstructural Investigations of As-Fabricated, Long-Term Thermaily Aged and Neutron-irradiated RPV Materials: An Atom Probe Study," presented at the Workshop on Collaborative Research on Irradiation Effects in RPV Materials, Mol, Belgium, June 28,1995.

26. W. R. Corwin, "Heavy-Section Steel Irradiation Program Summary," presented at the Paul Scherrer Institute, Warenlingen, Switzerland, June 30, 1995.

27. S. K. Iskander and M. A. Sokolov, "HSSI Program Annealing Studies," presented at the Paul Scherrer Institute, Wurenlingen, Switzerland, June 30, 1995.

28. R. K. Nanstad, D. E. McCabe, M. A. Sokolov, and G. Gage, "Fracture Toughness Results from Precracked Charpy Specimens," presented at the Paul Scherrer Institute, Wurenlingen, Switzerland, June $30,1995$.

29. M. A. Sokolov, "Subsize Impact Specimen Studies," presented at the Paul Scherrer Institute, Wurenlingen, Switzerland, June 30, 1995.

30. R. K. Nanstad and M. A. Sokolov, "Foreign Experience with Thermal Annealing Response of RPV Materials," presented at the NRCNEI Industry Workshop on Reactor Pressure Vessel Integrity, Rockville, Maryland, July 11, 1995.

31. R. K. Nanstad, W. R. Corwin, F. M. Haggag, S. K. Iskander, D. E. McCabe, M. A. Sokolov, and R. E. Stoller, "Heavy-Section Steel Irradiation Program on Radiation Effects in Light-Water Reactor Pressure Vessel Materials," presented at the ASMEJJSME Pressure Vessel and Piping Conference, Honolulu, Hawaii, July 27, 1995.

32. W. R. Corwin, "Heavy-Section Steel Irradiation Program Summary," presented at CEA, Saclay, France, July $3,1995$.

33. S. K. Iskander and M. A. Sokolov, "HSSI Program Annealing Studies," presented at CEA, Saclay, France, July 3, 1995.

34. R. K. Nanstad, D. E. McCabe, M. A. Sokolov, and G. Gage, "Fracture Toughness Results from Precracked Charpy Specimens," presented at CEA, Saclay, France, July 3, 1995.

35. M. A. Sokolov, "Subsize Impact Specimen Studies," presented at CEA, Saclay, France, July 3, 1995.

36. F. M. Haggag and W. R. Corwin, "Effects of Irradiation and Thermal Aging of Stainless-Steel Cladding," presented at CEA, Saclay, France, July 3, 1995.

37. R. K. Nanstad, S. K. Iskander, D. E. McCabe, and M. A. Sokolov, "Fracture Toughness Curve Shift Studies," presented at CEA, Saclay, France, July 3, 1995.

38. M. K. Miller and K. F. Russell, "ORNL Atom Probe Research into Russian WER Steels," presented at an Invited Seminar, Institute of Theoretical and Experimental Physics, Moscow, Russia, July 3, 1995.

39. W. R. Corwin, "Heavy-Section Steel Irradiation Program Summary," presented at MPA, Stuttgart, Germany, July 6, 1995.

40. S. K. Iskander and M. A. Sokolov, "HSSI Program Annealing Studies," presented at MPA, Stuttgart, Germany, July 6, 1995.

41. R. K. Nanstad, D. E. McCabe, M. A. Sokolov, and G. Gage, "Fracture Toughness Results from

Precracked Charpy Specimens," presented at MPA, Stuttgart, Germany, July 6, 1995. 
42. M. A. Sokolov, "Subsize Impact Specimen Studies," presented at MPA, Stuttgart, Germany, July 6, 1995.

43. R. K. Nanstad, S. K. Iskander, D. E. McCabe, and M. A. Sokolov, "Fracture Toughness Curve Shift Studies," presented at MPA, Stuttgart, Germany, July 6, 1995.

44. M. K. Miller and K. F. Russell, "APFIM Characterization of a High-Phosphorus Russian RPV Weld," presented at the 42nd International Field Emission Symposium, Madison, Wisconsin, August 7-11, 1995.

45. P.Pareige, K. F. Russell, R. E. Stoller, and M. K. Miller, "Fine-Scale Microstructural investigations of As-Fabricated, Long-term Thermally Aged and Neutron-irradiated RPV Materials: An Atom Probe Study," presented at the 42nd International Field Emission Symposium, Madison, Wisconsin, August 7-11, 1995.

46. K. F. Russell and M. K. Miller, "APFIM Studies of Phase Transformations in a Thermally Aged FeCuNi Alloy," presented at the 42nd International Field Emission Symposium, Madison, Wisconsin, August 7-11, 1995.

47. D. J. Alexander, K. B. Alexander, M. K. Miller, and R. K. Nanstad, "The Effects of Aging at $343^{\circ} \mathrm{C}$ to $50,000 \mathrm{~h}$ on the Mechanical Properties and Microstructure of Type 308 Stainless Steel Weld Metal," presented at the 7th International Symposium on Environmental Degradation of Materials in Nuclear Power Systems - Water Reactors, Breckenridge, Colorado, August 8, 1995.

48. M. A. Sokolov, D. E. McCabe, S. K. Iskander, and R. K. Nanstad, "Comparison of Fracture Toughness and Charpy Impact Properties Recovery by Thermal Annealing of Irradiated Reactor Pressure Vessel Steels," presented at the 7th International Symposium on Environmental Degradation of Materials in Nuclear Power Systems - Water Reactors, Breckenridge, Colorado, August 8, 1995.

49. W. R. Corwin, R. K. Nanstad, D. J. Alexander, G. R. Odette, R. E. Stoller, and J. A. Wang, "Thermal Embrittlement of Reactor Vessel Steels," presented at the 13th International Conference on Structural Mechanics in Reactor Technology (SMiRT 13), Port Alegre, Brazil, August 13-18, 1995.

50. M. A. Sokolov, R. K. Nanstad, and D. J. Alexander, "An Improved Correlation Procedure for Subsize and Full-Size Charpy Impact Specimen Data," presented at the International Group on Radiation Damage Mechanisms - VI, Prague, Czech Republic, September 11-15, 1995.

51. M. A. Sokolov, S. K. Iskander, R. K. Nanstad, and D. E. McCabe, "Comparison of Fracture Toughness and Charpy Impact Properties Recovery by Thermal Annealing," presented at the International Group on Radiation Damage Mechanisms - VI, Prague, Czech Republic, September 11-15, 1995.

52. R. K. Nanstad, M. A. Sokolov, and D. E. McCabe, "Comparison of Fracture Toughness and Charpy Impact Toughness of Unirradiated and Irradiated RPV Steels," presented at the International Group on Radiation Damage Mechanisms - VI, Prague, Czech Republic, September 11-15, 1995.

53. R. K. Nanstad, D. E. McCabe, D. J. Alexander, M. A. Sokolov, and G. Gage, "Fracture Toughness of RPV Steels with Precracked Charpy and Other Small Specimens," presented at the International Group on Radiation Damage Mechanisms - VI, Prague, Czech Republic, September 11-15, 1995.

54. R. E. Stoller, "Recent Results of Molecular Dynamics Cascade Simulations: Implications for Embrittlement Modeling," presented at the International Group on Radiation Damage Mechanisms - VI, Prague, Czech Republic, September 11-15, 1995.

55. P. Pareige, R. E. Stoller, and M. K. Miller, "Microstructural Investigations of As-fabricated, Long-term Thermally Aged and Neutron-irradiated RPV Materials: An Atom Probe Study," presented at the International Group on Radiation Damage Mechanisms - VI, Prague, Czech Republic, September 11-15, 1995. 
56. P. Pareige, M. K. Miller, and R. E. Stoller, "APFIM Studies of the Phase Transformations in Thermally Aged Fernitic FeCuNi Alloys: A Comparison with Ageing under Neutron Irradiation," presented at the International Group on Radiation Damage Mechanisms - VI, Prague, Czech Republic, September 11-15, 1995.

57. P. Pareige, P. Auger, J. C. Van Duysen, M. K. Miller, and R. E. Stoller, "Comparisons of Neutron Irradiation Effects on the Microstructure of Different Nuclear Pressure Vessel Steels and Study of the Effects of Annealing," presented at the international Group on Radiation Damage Mechanisms - VI, Prague, Czech Republic, September 11-15, 1995.

58. R. E. Stoller, "Recent Results of Molecular Dynamics Cascade Simulations: Implications for Embrittlement Modeling," presented at the International Group on Radiation Damage Mechanisms - VI, Prague, Czech Republic, September 11-15, 1995. 


\title{
2. Fracture Toughness Shifts in High-Copper Weldments \\ (Series 5 and 6)
}

\author{
S. K. Iskander
}

\subsection{Introduction}

The objective of this task is to develop data addressing the current method of shifting the American Society of Mechanical Engineers (ASME) fracture toughness $\left(K_{1 e}, K_{12}\right.$, and $\left.K_{1 R}\right)$ curves to account for irradiation embrittlement in high-copper welds. The specific activities to be performed in this task are (1) the continuation of Phase 2 of the Fifth Irradiation Series and (2) the completion of the Sixth Irradiation Series, including the testing of the nine irradiated Italian crack-arrest specimens. The results of testing the Italian crack-arrest specimens have been analyzed, a draft NUREG report has been prepared, and the reviewers' comments are being incorporated. A better method for calculating the force needed to adjust the crack-mouth opening displacement (CMOD) has been implemented, and the final crack-arrest toughness of the Italian specimens is presented. As part of this task, irradiation of HSSI weld $73 \mathrm{~W}$ to a high fluence $\left[5 \times 10^{19}\right.$ neutrons $\left./ \mathrm{cm}^{2}(>1 \mathrm{MeV})\right]$ will be performed to determine whether the $\mathrm{K}_{\mathrm{Je}}$ curve shape change observed in the Fifth Series is exacerbated. A test plan that has been developed is presented, and specimen fabrication will begin shortly. The design and fabrication of the temperature and dosimetry verification capsules are performed under this task, but for purposes of continuity, their progress will be reported under Task 6 , where the design of the new irradiation facilities and capsules is performed.

\subsection{Results of Testing Irradiated A 508 Class 3 Crack-Arrest Specimens}

Background information on the nine irradiated crack-arrest specimens tested at ORNL and preliminary results were previously reported.' These specimens, which belong to the Italian Nuclear Regulatory Authorities, Agenzia National per la Protezione dell'Ambiente (ANPA), were encapsulated and irradiated at the Ford Nuclear Reactor (FNR) of the University of Michigan (U. of M.) under the supervision of Battelle Columbus.

The measured CMOD had to be adjusted; the reasons and the method used for the adjustment were described in a previous report. ${ }^{1}$ In the method used to adjust the CMOD, an intermediate calculation for crack-mouth opening force applied at the load line $(P)$ is required. An iterative scheme was used to calculate $P$, but a direct method has been suggested by J. G. Merkle.* It may be shown that the load-line crack-opening force, $P$, is:

$$
P=\frac{0.0924(2 V)_{M}}{\alpha\left[(M-0.25)\left(C_{0}-C_{1}\right)+0.0924 C_{0}\right]}
$$

where

$$
\alpha=\frac{1}{E B} \sqrt{\frac{B}{B_{N}}} .
$$

In the above equations,

$$
\begin{aligned}
& E=\text { Young's modulus, } \\
& B=\text { specimen thickness, }
\end{aligned}
$$

•J, G. Merkle, Oak Ridge Natl. Lab., personal communication to S. K. Iskander, Oak Ridge Natl. Lab., August 2, 1995. 

$\mathrm{B}_{\mathrm{N}}=$ net specimen thickness at the root of the side grooves,
$\mathrm{C}_{0}=$ specimen compliance at the front face of the crack-arrest specimen,
$C_{1}=$ specimen compliance at a relative distance of 0.1576 in. of the nominal specimen width from the load line and toward the front face of the specimen,
$M$ = distance from the load line (relative to the nominal specimen width), at which the CMOD was
$(2 \mathrm{~V})_{M}=\quad \begin{aligned} & \text { measured, and } \\ & \text { measured } \mathrm{CMOD}\end{aligned}$

The crack-arrest specimens were machined by ANPA from a forging material produced in ltaly that conforms to American Society for Testing and Materials (ASTM) "Specification for Quenched and Tempered Vacuum-Treated Carbon and Alloy Steel Forgings for Pressure Vessels, Class $3^{\prime \prime}$ (A $508 \mathrm{Cl}$. 3); the chemical composition is given in Table 2.1. The room-temperature (RT) tensile yield and ultimate strengths were 463 and $605 \mathrm{MPa}$, respectively, and increased $\sim 9$ and $4 \%$, respectively, when irradiated at a nominal temperature and fluence of $288^{\circ} \mathrm{C}$ and $3 \times 10^{19}$ neutrons $/ \mathrm{cm}^{2}(>1 \mathrm{MeV}$ ), respectively. The CVN $41-J$ transition temperature and upper-shelf energy (USE) for the unirradiated specimens were $-58^{\circ} \mathrm{C}$ and $260 \mathrm{~J}$, respectively, and changed by +11 and $-6 \%$, respectively, for the same irradiation conditions just mentioned. ${ }^{2}$ In particular, the CVN 41-J transition temperature shift for the irradiation conditions mentioned is $11 \mathrm{C}$.* These small changes are due to the relatively small copper and moderate nickel contents $\left(0.06\right.$ and $0.74 \%$, respectively). An $R T_{\text {NDT }}$ of $-12.5^{\circ} \mathrm{C}$ was determined by Terni (the Italian steel manufacturer that produced the forging) from the DWT test results.

Table 2.1. Chemical composition of the A 508 class 3 forging used by ANPA to machine the crack-arrest specimens

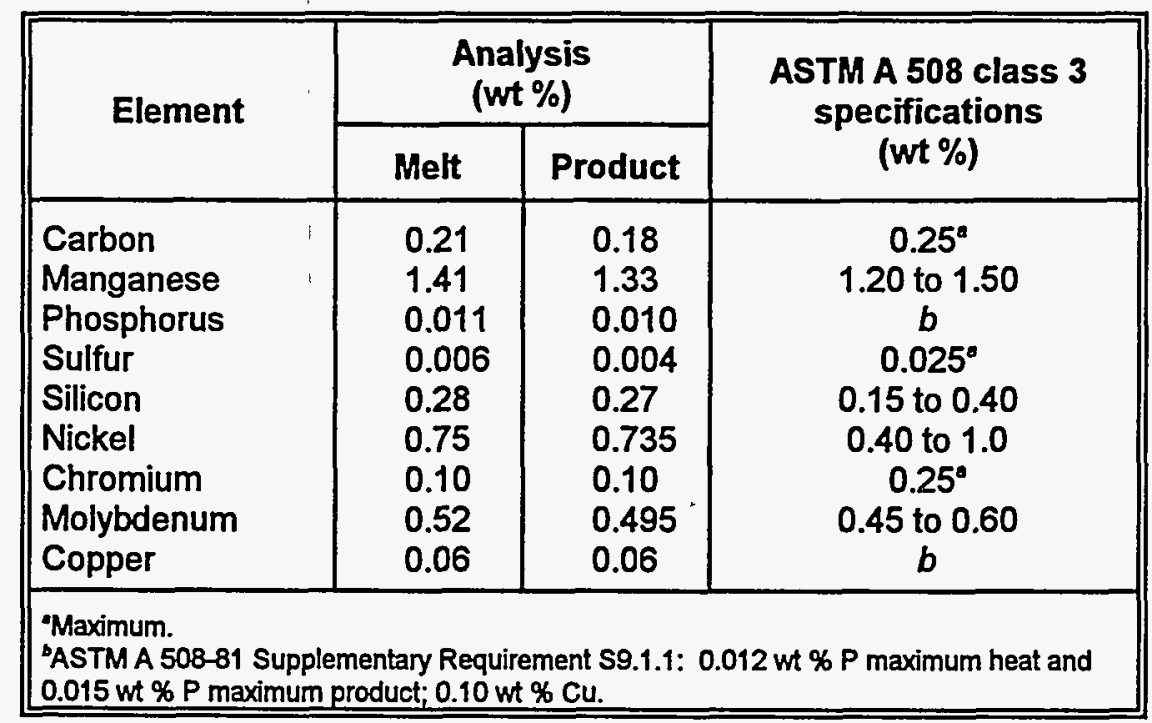

Figure 2.1 compares the crack-arrest toughness of the unirradiated and irradiated specimens. The unirradiated tests were performed by ANPA and the irradiated tests by ORNL. Figure 2.1 also shows a mean curve, as well as the ASME $K_{1 a}$ curve for the unirradiated and irradiated specimens. The shift of the mean curve due to neutron irradiation is approximately the same as the CVN 41-J temperature shift. It is significant to note that the small (averaging approximately $10 \mathrm{C}$ ) shifts in the mean crack-arrest toughness curves confirm that a low-copper content in A 508 class 3 forging material can be expected to result in small shifts of the transition toughness curve. It is not possible to draw final conclusions about possible shape changes of the crack-arrest toughness curve from the small amount of data available for the irradiated ANPA specimens.

\footnotetext{
*A distinction is made between temperatures that are designated as " ${ }^{\circ} \mathrm{C}$ " and temperature differences, which are designated as " $\mathrm{C}$ " without the degree symbol.
} 


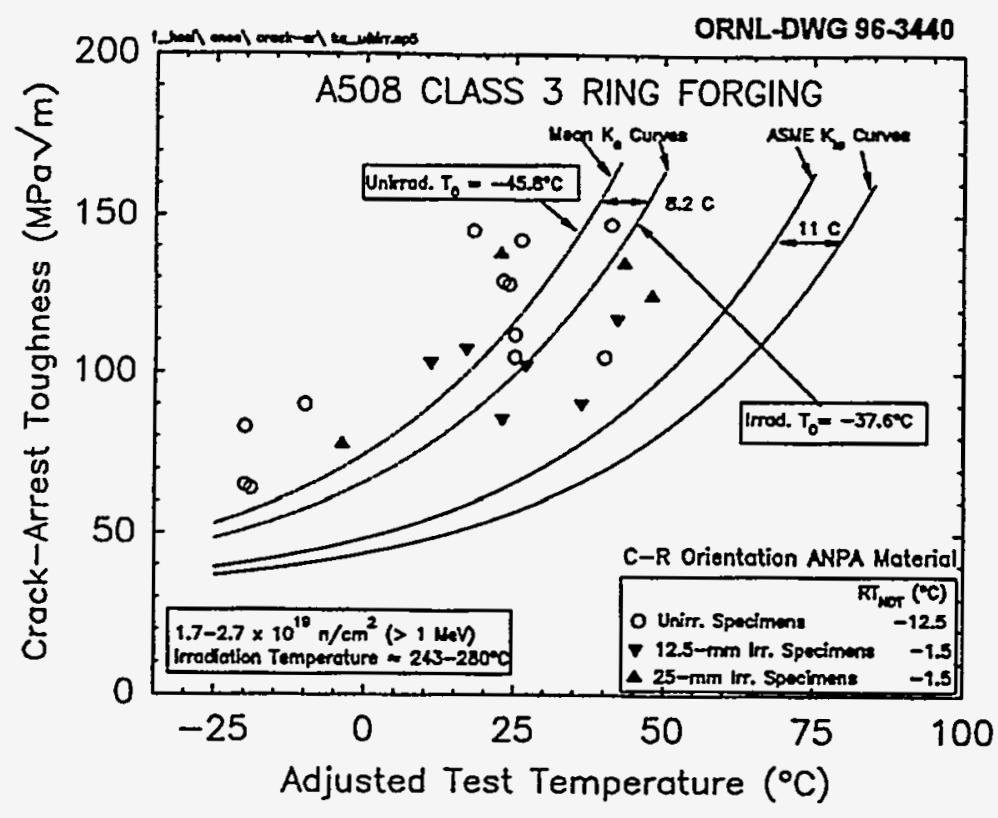

Figure 2.1. Unirradiated and irradiated crack-arrest toughness for the ANPA A 508 class 3 forging material showing the relationships between the unirradiated and irradiated data.

\subsection{Test Plan for the High-Fluence Capsule}

The purpose of this capsule is to determine whether the slight $K_{\mathrm{Jc}}$ curve shape change observed for HSSI weld $73 \mathrm{~W}$ irradiated to $1.5 \times 10^{19}$ neutrons $/ \mathrm{cm}^{2}(>1 \mathrm{MeV})$ is exacerbated at greater fluences. A meeting was held between R. K. Nanstad, D. E. McCabe, and S. K. Iskander to develop a test plan for the high-fluence $\left[\sim 5 \times 10^{19}\right.$ neutrons $\left./ \mathrm{cm}^{2}(>1 \mathrm{MeV})\right]$ weld $73 \mathrm{~W}$ capsule. The first task is to confirm that the $K_{\mathrm{Jc}}$ toughness of the second batch of weld $73 \mathrm{~W}$ manufactured is comparable to the first batch that was depleted in the Fifth and Sixth Series. The next task is to determine the specimen complement of the long-term capsule in terms of the number and size of 0.5TC (T), 1TC (T), precracked CVN (PCVN), CVN, and tensile specimens. The test plan and specimen complement for both tasks are given below.

The results of testing 1TC (T) specimens from the Fith Series exhibited the ranges of $\mathrm{K}_{\mathrm{Jc}}$ shown in Table 2.2. The number of unirradiated $0.5 T C(T)$ and 1TC $(T)$ specimens to be tested at the various temperatures are shown in Table 2.3. The purpose is to compare the values obtained using 1TC $(T)$ specimens with those in the Fifth Series and to evaluate the range of values exhibited by the $0.5 \mathrm{TC}(\mathrm{T})$ specimens. The highest temperatures planned at this time for the $1 \mathrm{TC}(\mathrm{T})$ specimens will be $-15^{\circ} \mathrm{C}$, and $-30^{\circ} \mathrm{C}$ for the $0.5 \mathrm{TC}(\mathrm{T})$ specimens. Further test temperatures will be chosen based on the results obtained.

Twelve PCVN specimens will be tested in the irradiated and unirradiated conditions. This will provide more data on the toughness capacity of this type of specimen. 
Table 2.2. The range of crack-initiation toughness, $K_{\mathrm{Je}}$, for the $1 T C(T)$ specimens exhibited in the Fifth Irradiation Series

\begin{tabular}{|c|c|c|c|}
\hline $\begin{array}{c}\text { Number } \\
\text { of } \\
\text { specimens }\end{array}$ & $\begin{array}{c}\text { Test } \\
\text { temperature } \\
\left({ }^{\circ} \mathrm{C}\right)\end{array}$ & $\begin{array}{c}\text { Range of } \\
\text { ductile crack } \\
\text { extension } \\
(\mathbf{m m})\end{array}$ & $\begin{array}{c}\text { Range of initiation } \\
\text { toughness, } K_{\mathrm{Jc}} \\
(\mathrm{MPa} / \mathrm{m})\end{array}$ \\
\hline 9 & -80 & 0 & 60 to 114 \\
6 & -50 & 0 to 0.11 & 90 to 146 \\
5 & -30 & 0.09 to 0.17 & 128 to 174 \\
8 & -15 & 0.10 to 1.77 & 153 to 325 \\
2 & 0 & 0.59 to 1.02 & 250 to 448 \\
1 & 23 & 1.75 & No cleavage \\
2 & 50 & 6.40 & Pop-in, 393 \\
No cleavage \\
\hline
\end{tabular}


Table 2.3.Test plan for weld $73 \mathrm{~W}$ high-fluence capsule

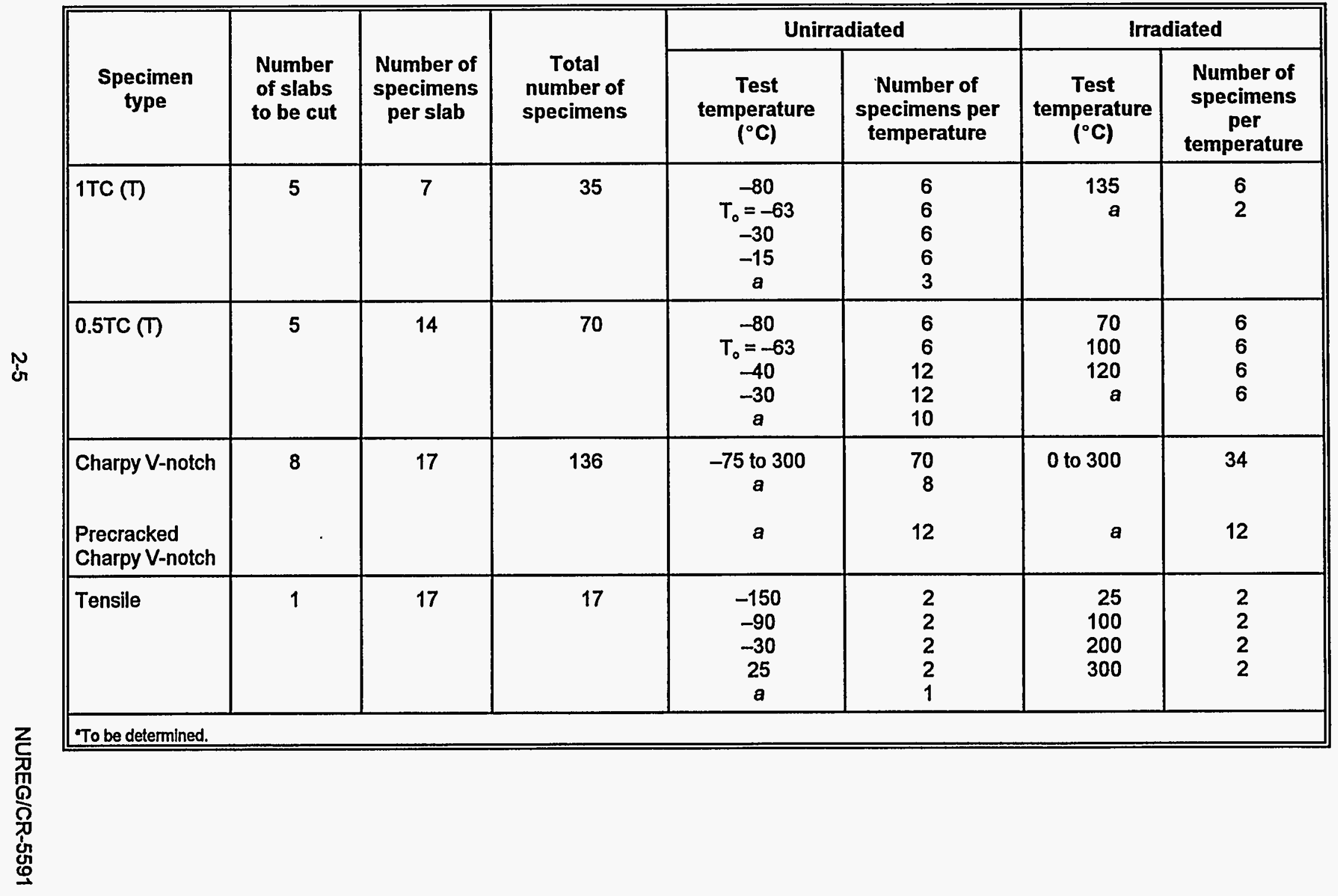


As a guide to the limits of the fracture toughness measuring capacity of the two specimen sizes at $R T, 20^{\circ} \mathrm{C}$, the following equation from Draft 10 of the ASTM "Test Practice for Fracture Toughness in the Transition Range" was used. The equation gives the toughness level at which there is a significant loss of constraint:

$$
K_{\mathrm{Jc}(\text { limit })}=\left(\frac{E b_{0} \sigma_{y s}}{30}\right)^{1 / 2} .
$$

Using the following values at $20^{\circ} \mathrm{C}$ for the various terms of Equation (2.3):

$$
\begin{aligned}
E & =\quad \text { Young's modulus, } 206 \mathrm{GPa}(\sim 30,000 \mathrm{ksi}), \\
b_{0} & =\text { remaining ligament, } 25 \mathrm{~mm} \text {, for a } 1 \mathrm{TC}(\mathrm{T}) \text {, and } \\
\sigma_{\mathrm{ys}} & =\text { yield strength, for unirradiated weld } 73 \mathrm{~W} \text { material, } 495 \mathrm{MPa}(\sim 72 \mathrm{ksi}) .
\end{aligned}
$$

For a 1TC $(T)$, this gives $K_{\text {Je }(\| \mathrm{mm})}=295 \mathrm{MPa} \sqrt{\mathrm{m}}\left(268 \mathrm{ksi} / \mathrm{in}\right.$.), and for a $0.5 \mathrm{TC}(T)$ specimen, $K_{\text {Jefllmk })}=295 / \sqrt{2}=$ $209 \mathrm{MPa} \sqrt{\mathrm{m}}(190 \mathrm{ksi} / \mathrm{in}$.$) .$

A shift in the CVN $41-J$ transition temperature $\left(\Delta T_{41,1}\right)$ of $150 \mathrm{C}$ due to a fluence of $5 \times 10^{19}$ neutrons/cm $(>1 \mathrm{MeV})$ has been estimated based on the $82 \mathrm{C}$ shift at $1.5 \times 10^{19}$ neutrons $/ \mathrm{cm}^{2}(>1 \mathrm{MeV})$ using the test reactor observations from Odette: ${ }^{3}$

$$
\Delta T_{41 \mathrm{~J}}^{\prime}=\Delta T_{41 \mathrm{~J}}\left(\frac{\Phi^{\prime}}{\Phi}\right)^{0.5}
$$

where

$$
\begin{aligned}
& \Delta T^{\prime}{ }_{41 \mathrm{~J}}=\quad \text { shift at a fluence, } \Phi^{\prime} \text {, of } 5 \times 10^{19} \text { neutrons } / \mathrm{cm}^{2}(>1 \mathrm{MeV}) \text {, } \\
& \Delta T_{\text {its }}=\quad 82 \mathrm{C} \text { shift at a fluence, } \Phi \text {, of } 1.5 \times 10^{19} \text { neutrons } / \mathrm{cm}^{2}(>1 \mathrm{MeV}) \text {, } \\
& \Phi^{\prime}=\text { fluence of } 5 \times 10^{19} \text { neutrons } / \mathrm{cm}^{2}(>1 \mathrm{MeV}) \text {, } \\
& \Phi=\text { fluence of } 1.5 \times 10^{19} \text { neutrons } / \mathrm{cm}^{2} \text {. }
\end{aligned}
$$

The $\Delta T_{411}$ shift at $1.5 \times 10^{19}$ neutrons $/ \mathrm{cm}^{2}$ calculated using the U.S. NRC Regulatory Guide 1.99, Rev. 2 (RG 1.99), is $123^{\circ} \mathrm{C}$. The fluence factors for 1.5 and $5 \times 10^{\text {t9 }}$ neutrons $/ \mathrm{cm}^{2}(>1 \mathrm{MeV})$ are 1.1123 and 1.402 , respectively. The RG 1.99 shift corresponding to $5 \times 10^{19}$ neutrons $/ \mathrm{cm}^{2}$ is $110 \times 1.402=154 \mathrm{~K}$, which is approximately that calculated using Equation (2.4). The chemistry factor (CF) for weld $73 \mathrm{~W}$ is $110 \mathrm{C} \mathrm{(198} \mathrm{F).} \mathrm{An}$ assumed $\mathrm{CF}$ for weld $73 \mathrm{~W}$ can be calculated using the measured shift of $82 \mathrm{C}$ : $82 / 1.1123=73.7 \mathrm{~K}$. By passing the RG 1.99 trend curve through this shift and extrapolating it to a fluence of $5 \times 10^{19}$ neutrons $/ \mathrm{cm}^{2}: 73.7 \times 1.402=a$ shift of $103 \mathrm{~K}$

Up to 70 unirradiated and 30 irradiated CVN specimens could be tested for a statistically equivalent comparison to the 85 unirradiated and the 55 irradiated CVN specimens, respectively, that were tested for the Fifth Series. The tensile temperature range is also shown in Table 2.3.

The proposed specimen complement to be irradiated is shown in Table 2.4. It should be noted that it is equivalent in volume to $151 \mathrm{TC}(\mathrm{T})$ specimens, and that the square-end tensile specimens are equivalent to CVN specimens in external dimensions. 
Table 2.4. Proposed irradiated specimen complement for the high-fluence capsule

\begin{tabular}{||l|c|}
\hline \multicolumn{1}{|c|}{ Specimen type } & $\begin{array}{c}\text { Number of } \\
\text { specimens }\end{array}$ \\
\hline 1TC $(T)$ & 8 \\
0.5TC $(T)$ & 24 \\
Precracked Charpy V-notch & 12 \\
Charpy V-notch & 34 \\
Tensile & 8 \\
\hline -Square-end tensile specimens that are equivalent in volume \\
requirements to Charpy V-notch specimens.
\end{tabular}

The proposed test temperatures for the irradiated compacts are estimates, and actual temperatures will be chosen after the irradiated CVN testing is completed. For the irradiated tests, six 1TC (T) specimens are available to test at a temperature estimated at $135^{\circ} \mathrm{C}$ [estimated by adding the $150 \mathrm{C}$ shift calculated above to the highest test temperature estimated for $1 \mathrm{TC}(\mathrm{T})$ to fracture in a cleavage mode $\left.\left(-15^{\circ} \mathrm{C}\right)\right]$. Two additional $1 \mathrm{TC}(\mathrm{T})$ specimens have been included as spares for inevitable contingencies. A set of six $0.5 \mathrm{TC}(\mathrm{T})$ specimens will be tested at the three temperatures shown in Table 2.3 and another set of six at a temperature to be determined. In addition, tests on one or two $0.5 \mathrm{TC}(T)$ specimens will be conducted to verify the inboard versus outboard load-line attachment of the clip gage on the same specimen. The results will not be strictly applicable, since the remaining ligament between the hole and the notch of the clip gage is $0.100 \mathrm{in}$. smaller than in an outboard specimen that is designed exclusively for outboard attachment of the clip gage.

Although it is desirable to test 1TC $(T)$ specimens at the same temperature as the $0.5 T C(T)$ specimens, there is no more room in the capsule. There is a possibility that a set of $0.5 T C(T)$ and 1TC $(T)$ specimens will be included in the long-term Midland capsule.

\section{References}

1. S. K. Iskander et al., Martin Marietta Energy Systems, Inc., Oak Ridge Natl. Lab., "Fracture Toughness Shift in High-Copper Weldments," in Heavy-Section Steel Irradiation Program Semiannual Progress Report April-September 1994, USNRC Report NUREG/CR-5591, Vol. 5, No. 2 (ORNLTM-11568N5\&N2), 1995.*

2. C. W. Marschall et al., Final Report on Effects of Fast-Neutron Irradiation on the Mechanical Properties of an SA508 Class 3 Ring Forging to the Italian Agenzia Nazionale per la Protezione Dell'Ambiente, Battelle, Columbus, Ohio, November 1995.†

3. G. R. Odette and G. E. Lucas, "Irradiation Embrittlement of Reactor Pressure Vessel Steels: Mechanisms, Models, and Data Correlations," pp. 206-41 in Radiation Embrittlement of Nuclear Pressure Vessel Steels: An International Review (Second Volume), ASTM STP 909, L. E. Steele, Ed., American Society for Testing and Materials, Philadelphia, 1986.†

"Avaliable for purchase from National Technical Information Service, Springfield, VA 22161.

†Available in public technical libraries. 


\title{
3. Fracture Toughness Curve Shifts in Low Upper-Shelf Welds (Series 8)
}

\author{
S. K. Iskander, R. K. Nanstad, D. D. Randolph, ${ }^{*}$ and E. T. Manneschmidt
}

This task examines the fracture toughness curve shifts and changes in shape for irradiated welds with low Charpy USE. This task was specifically designed to address questions raised by the Advisory Committee for Reactor Safeguards concerning the shape of the $K_{l c}$ curve for irradiated welds with a low USE. In particular, it will clarify whether the high concentration of inclusions in low-USE welds results in a transition relationship and behavior significantly different from high-USE welds. The information developed under this task will augment information obtained from other HSSI tasks performed on two high-USE weldments under the Fifth and Sixth Irradiation Series and on a commercial, low USE under the Tenth Irradiation Series. The results will provide an expanded basis for accounting for irradiation-induced embrittlement in RPV materials.

To provide material for this and for the annealing task (HSSI Series 9), three trial low-USE welds were ordered from ABB-Combustion Engineering (ABB-CE), Chattanooga, Tennessee, who had also fabricated the welds for the Fifth and Sixth Series. Two of the three welds previously received included chemical and mechanical properties obtained by ABB-CE and have been reported in the previous semiannual. ' The third weld has now been received, and the current status and test plans for all three welds will be presented here.

Linde 80 flux was used for all three welds, designated welds 1,2 , and 3 . Weld 1 was fabricated with $73 W$ weld wire, which had copper added to the melt to reduce the variations that are associated with copper-coated weld wires. The other two welds were fabricated with a commercially available copper-coated weld wire, L-TEC, heat 44112. Welds 2 and 3 had a target copper level of 0.31 and $0.45 w t \%$, respectively, and welds 1 and 3 have been delivered to ORNL. The $0.31 \mathrm{wt} \% \mathrm{Cu}$ level for weld 2 could not be attained using the copper-coated weld wire, and the coating was stripped from the wire, which contains $0.07 \mathrm{wt} \% \mathrm{Cu}$. To attain the target copper level, supplemental copper was added to the weld puddle using an ABB-CE proprietary process. Weld 3 was fabricated with the same heat of the L-TEC 44 copper-coated weld wire as weld 2 but with supplemental copper added to the weld puddle, which resulted in a weldment containing an average of $0.424 \mathrm{wt} \% \mathrm{Cu}$. The copper content and weld wire selections were previously reported. ${ }^{2}$

The chemical analysis of weld $2 \mathrm{~A}$ (weld 2 did not meet the target copper level of $0.31 \%$, and the refabricated weld was redesignated weld $2 A$ ) will be presented here. Table 3.1 gives the variation in chemical analysis through the thickness of weld 2A, and Table 3.2 compares the average chemical composition of all three welds to weld $73 \mathrm{~W}$. It is interesting to note that the two welds fabricated from the commercially available copper-coated weld wire (L-TEC, heat 44112) have higher impurity levels of phosphorus and sulfur and much lower chromium contents than those fabricated from weld $73 \mathrm{~W}$. At the request of ORNL, weld $2 \mathrm{~A}$ did not undergo any postweld heat treatment (PWHT), except for a hydrogen bake at $204.4^{\circ} \mathrm{C}\left(400^{\circ} \mathrm{F}\right)$ to prevent cracking.

Toughness tests are planned for the three welds (see Table 3.3). Since the CVN impact energy curve for weld $73 \mathrm{~W}$ was based on 85 specimens, additional CVN impact testing is planned to obtain a better statistical basis for the three welds, particularly at the upper-shelf temperatures. The initiation fracture toughness in the transition region, $K_{J c}$ for the three welds will also be determined. Welds 1 and 3 have undergone $P W H T$ at $607^{\circ} \mathrm{C}\left(1125^{\circ} \mathrm{C}\right)$ for $40 \mathrm{~h}$. Except for the $204.4^{\circ} \mathrm{C}\left(400^{\circ} \mathrm{F}\right) 8-\mathrm{h}$ hydrogen bake to prevent cracking, weld 2A was not given the PWHT of welds 1 and 3 so that the effects of various PWHTs on matrix copper could be studied. In the initial phase of this task, sufficient material for the testing of weld $2 \mathrm{~A}$ will be given the same PWHT as that of welds 1 and 3 , and atom probe studies are planned before and after PWHT. The RT tensile properties of weld $2 A$ will also be measured. Other phases of this study could include more tests, e.g., candidate annealing temperatures of 343 and $454^{\circ} \mathrm{C}$ $\left(650\right.$ and $\left.850^{\circ} \mathrm{F}\right)$.

An evaluation of all three welds will be performed so that one or possibly two welds can be chosen for fabrication in sufficient quantities for the Eighth and Ninth Irradiation Series. To estimate the linear feet of weld needed for the

*ABB-Combustion Engineering, Chattanooga, Tennessee. 
Table 3:1. Results of chemical analysis through the thickness of weld $2 A$ using weld wire L-TEC 44, heat 44112 , and Linde 80 flux [hydrogen baked at $204.4^{\circ} \mathrm{C}\left(400^{\circ} \mathrm{F}\right)$ for $8 \mathrm{~h}$ ]

\begin{tabular}{|c|c|c|c|c|c|c|}
\hline \multirow[b]{2}{*}{ Element } & \multicolumn{4}{|c|}{$\begin{array}{l}\text { Chemical analysis at various depths from top of weld } \\
\text { (wt \%) }\end{array}$} & \multirow[b]{2}{*}{ Average } & \multirow{2}{*}{$\begin{array}{l}\text { Standard } \\
\text { deviation }\end{array}$} \\
\hline & $\begin{array}{c}\text { At } \\
25.4 \mathrm{~mm} \\
(1 \mathrm{in} .)\end{array}$ & $\begin{array}{c}\text { At } \\
63.5 \mathrm{~mm} \\
(2.5 \mathrm{in} .)\end{array}$ & $\begin{array}{c}\text { At } \\
107.95 \mathrm{~mm} \\
\text { (4.25 in.) }\end{array}$ & $\begin{array}{c}\text { At } \\
152.4 \mathrm{~mm} \\
(6 \mathrm{in} .)\end{array}$ & & \\
\hline Carbon & 0.082 & 0.076 & 0.083 & 0.083 & 0.081 & 0.0034 \\
\hline Manaanese & 1660 & 1710 & 1.660 & 1660 & 1.673 & 0.0250 \\
\hline Phosphorus & 0.012 & 0.012 & 0.012 & 0.013 & 0.012 & 0.0005 \\
\hline Sulfur & 0.010 & 0.010 & 0.010 & 0.010 & 0.010 & 0.0000 \\
\hline Silicon & 0.340 & 0.360 & 0.320 & 0.380 & 0.350 & 0.0258 \\
\hline Nickel & 0.600 & 0.600 & 0.590 & 0.570 & 0.590 & 0.0141 \\
\hline Chromium & 0.070 & 0.070 & 0.080 & 0.080 & 0.075 & 0.0058 \\
\hline Molybdenum & 0.430 & 0.430 & 0.430 & 0.410 & 0.425 & 0.0100 \\
\hline Vanadium & 0.003 & 0.003 & 0.003 & 0.003 & 0.003 & 0.0000 \\
\hline Niobium & 0.003 & 0.003 & 0.004 & 0.004 & 0.004 & 0.0006 \\
\hline Titanium & 0.002 & 0.002 & 0.002 & 0.002 & 0.002 & 0.0000 \\
\hline Cobalt & 0.011 & 0.011 & 0.011 & 0.011 & 0.011 & 0.0000 \\
\hline Copper & 0.330 & 0.330 & 0.330 & 0.340 & 0.333 & 0.0050 \\
\hline Aluminum & 0.007 & 0.007 & 0.007 & 0.007 & 0.007 & 0.0000 \\
\hline Boron & $<0.001$ & $<0.001$ & $<0.001$ & $<0.001$ & $<0.001$ & 0.0000 \\
\hline Tungsten & 0.010 & 0.010 & 0.010 & 0.010 & 0.010 & 0.0000 \\
\hline Arsenic & 0.006 & 0.005 & 0.006 & 0.006 & 0.006 & 0.0005 \\
\hline Tin & 0.012 & 0.013 & 0.012 & 0.012 & 0.012 & 0.0005 \\
\hline Zirconium & 0.001 & 0.001 & 0.001 & 0.001 & 0.001 & 0.0000 \\
\hline
\end{tabular}

Table 3.2. Comparison of chemical composition of weld $73 W$ (Linde 124 flux) and welds $1,2 A$, and 3 fabricated with weld wire L-TEC, heat 44112, and Linde 80 flux

\begin{tabular}{||l|c|c|c|c|c|c|c|c|c|c||}
\hline \multirow{3}{*}{ Weld } & \multicolumn{10}{|c|}{$\begin{array}{c}\text { Composition } \\
\text { (wt \%) }\end{array}$} \\
\cline { 2 - 13 } & $\mathbf{C}$ & Mn & P & S & Si & Cr & Ni & Mo & Cu & V \\
\hline $73 W$ & 0.098 & 1.56 & 0.005 & 0.005 & 0.45 & 0.25 & 0.60 & 0.58 & $\mathbf{0 . 3 1}$ & 0.003 \\
1 & 0.092 & 1.666 & 0.008 & 0.006 & 0.356 & 0.248 & 0.600 & 0.548 & $\mathbf{0 . 3 1 2}$ & 0.003 \\
$2 \mathrm{~A}$ & 0.081 & 1.673 & 0.012 & 0.010 & 0.350 & 0.075 & 0.590 & 0.425 & $\mathbf{0 . 3 3 3}$ & 0.003 \\
3 & 0.084 & 1.706 & 0.015 & 0.011 & 0.396 & 0.086 & 0.598 & 0.430 & $\mathbf{0 . 4 2 4}$ & 0.003 \\
\hline
\end{tabular}


Table 3.3. Test plans for three low upper-shelf welds fabricated with Linde 80 flux

\begin{tabular}{|c|c|c|c|c|c|c|}
\hline Weld & $\begin{array}{l}\text { Copper } \\
\text { (wt \%) }\end{array}$ & $\begin{array}{l}\text { Present } \\
\text { PWHT, } \\
{ }^{\circ} \mathrm{C}\left({ }^{\circ} \mathrm{F}\right)\end{array}$ & $\begin{array}{l}\text { Planned } \\
\text { phase } 1 \\
\text { PWHT, } \\
{ }^{\circ} \mathrm{C}\left({ }^{\circ} \mathrm{F}\right)\end{array}$ & $\begin{array}{l}\text { Tensil } \\
\text { e } \\
\text { tests } \\
\text { at } R^{b}\end{array}$ & $\begin{array}{l}\text { Charpy } \\
\text { tests }\end{array}$ & $\begin{array}{c}1 T C(T) \\
\text { at } T_{0}\end{array}$ \\
\hline $1(73 W)$ & 0.312 & $607(1125) / 40 \mathrm{~h}$ & None & & 25 & 8 \\
\hline $2 A(L-T E C)^{c}$ & 0.333 & $204(400) / 8 h^{d}$ & $607(1125) / 40 \mathrm{~h}^{\circ}$ & 2 & 25 & 8 \\
\hline 3 (L-TEC) & 0.424 & $607(1125) / 40 \mathrm{~h}$ & None & & 25 & 8 \\
\hline \multicolumn{7}{|c|}{$\begin{array}{l}\text { Note: No drop-weight testing planned. } \\
\text { 'PWHT = Postweld heat treatment. } \\
\text { "RT = Room temperature. } \\
\text { 'Only enough of weld } 2 \mathrm{~A} \text { will be PWHT for tests below. } \\
\text { dHydrogen bake to prevent cracking. } \\
\text {-Atom probe examination before and after PWHT. }\end{array}$} \\
\hline
\end{tabular}

Eighth and Ninth Series, a detailed test plan must first be developed, particularly with regard for the thickness of the compact tension specimens. A sufficiently thick compact tension specimen is required so that the toughness at high-USE levels can be defined, which is necessary to determine whether the shape of the toughness curve in the transition region changes due to irradiation. The development of the new test practice for fracture toughness in the transition region is very promising, since it allows for the use of relatively small specimens tested near the $100-\mathrm{MPa} \cdot \sqrt{\mathrm{m}}$ level; the entire fracture toughness curve can be determined using 25 -mm-thick compact tension [1TC (T)] specimens, perhaps even with specimens as small as $0.5 \mathrm{TC}(\mathrm{T})$. However, to determine the possible changes in slope, a specimen with a capacity of 150 to $200 \mathrm{MPa} \cdot \sqrt{\mathrm{m}}$ is needed, which may require a 2TC (T) specimen. The results from the ongoing Tenth Irradiation Series, which investigates a commercial low-USE weld, will also be taken into account in planning the Eighth and Ninth Irradiation Series.

\section{References}

1. S. K. Iskander et al., Martin Marietta Energy Systems, Inc., Oak Ridge Natl. Lab., "Fracture Toughness Curve Shift in Low Upper-Shelf Weld," in Heavy-Section Steel Irradiation Program Semiannual Progress Report October 1994-March 1995, USNRC Report NUREG/CR-5591, Vol. 6, No. 1 (ORNLTM-11568N6\&N1), 1995."

2. S. K. Iskander, E. T. Manneschmidt, and K. W. Boling, Martin Marietta Energy Systems, Inc., Oak Ridge Natl. Lab., "K $\mathrm{K}_{\mathrm{a}}$ Curve Shift in High-Copper Welds," in Heavy-Section Steel Irradiation Program Semiannual Progress Report October 1993-March 1994, USNRC Report NUREG/CR-5591, Vol. 5, No. 1 (ORNL/TM-11568N5\&N1), 1995."

"Available for purchase from National Technical Information Service, Springfield, VA 22161. 


\title{
4. Irradiation Effects in a Commercial Low Upper-Shelf Weld (Series 10)
}

\author{
D. E. McCabe, S. K. Iskander, and D. W. Heatherly
}

\subsection{Introduction}

The purpose of the Tenth Irradiation Series was to evaluate the before-and-after irradiation fracture toughness properties of commercially produced WF-70 weld metal. The material has been obtained from Unit 1 of the Midland Reactor of Consumers Power, Midland, Michigan. This vessel became available for test sampling and evaluation when Consumers Power aborted plans to operate the facility. Weld metal WF-70 was used in all girth welds; this designation indicates that a specific lot of Linde 80 weld flux was used that produces low CVN upper-shelf fracture toughness. LUS welds and weld metal WF-70, in particular, have been a source of concern for several currently operating nuclear power production facilities. The beltline weld of the Midland vessel was sampled completely around the girth, and the Tenth Irradiation Series received seven segments approximately $1 \mathrm{~m}$ long (40 in.). The nozzle course weld was similarly sampled, and this project received two of the available segments. These two were spaced about $180^{\circ}$ apart.

\subsection{Irradiated Specimen Test Results}

The baseline properties from tensile tests, Charpy transition curves, DWT-NDT determinations, and chemical compositions have been reported elsewhere.' These results confirmed that both welds were WF-70 with the expected properties. However, there was a difference in copper content and material yield strengths between the nozzle course WF-70 and the beltline WF-70 welds: nominally $0.256 \% \mathrm{Cu}$ and $407 \mathrm{MPa}(59 \mathrm{ksi})$ yield strength in the beltline weld and nominally $0.40 \% \mathrm{Cu}$ and $545 \mathrm{MPa}(79 \mathrm{ksi})$ yield strength in the nozzle course weld. However, the toughness as determined by the CVN and DWT-NDT tests was not different. Fracture mechanics tests, on the other hand, showed a significant difference in the fracture toughness of the beltine and nozzle course welds; the transition temperature of the nozzle course weld was about $20^{\circ} \mathrm{C}$ higher than that of the beltline weld (see Figures 4.1 and 4.2). Also, the J-R curves showed some difference (see Figure 4.3). These results have also been reported. ${ }^{2}$

The irradiation experiments on these materials have been the ongoing activity during this reporting period. Exposures made involved two scoping capsules, designated capsules 10.01 and 10.02, and two full-size capsules, designated capsules 10.05 and 10.06. The two scoping capsules each contained about $20 \mathrm{CVN}, 8$ tensile, and $41 / 2 \mathrm{~T}$ compact specimens. These scoping capsules were irradiated at $288^{\circ} \mathrm{C}\left(550^{\circ} \mathrm{F}\right)$, receiving a fluence of $0.5 \times 10^{19}$ neutrons $/ \mathrm{cm}^{2}(>1 \mathrm{MeV}$ ). Capsule 10.05 contained about $371 \mathrm{~T}$ and $241 / 2 \mathrm{~T}$ compact specimens of beltline WF-70 weld as well as $68 \mathrm{CVN}$ specimens, divided evenly between beltline and nozzle course welds. The exposure was also $288^{\circ} \mathrm{C}\left(550^{\circ} \mathrm{F}\right)$, but the fluence was $1 \times 10^{19}$ neutrons $/ \mathrm{cm}^{2}(>1 \mathrm{MeV})$. Capsule 10.06 contained the bulk of the nozzle course compact specimens. There also were about 15 crack-arrest-type specimens containing beltline welds in capsule 10.06. The exposure conditions were the same as for capsule 10.05. The testing of specimens from capsules 10.01, 10.02, and 10.05 is complete, and the results have been reported. ${ }^{3}$

The master curve 4 for irradiated beltline weld metal from capsule 10.05 is presented in Figure 4.4. The curve fit to the data suggests a reference temperature, $T_{0}($ at $100 \mathrm{MPa} / \mathrm{m})$, of about $32^{\circ} \mathrm{C}\left(90^{\circ} \mathrm{F}\right)$. This can be compared to the $T_{0}($ at $100 \mathrm{MPa} / \mathrm{m})$ of about $-55^{\circ} \mathrm{C}\left(-67^{\circ} \mathrm{F}\right)$ shown in Figure 4.1. These curves indicate a quasi-static fracture toughness shift of $87^{\circ} \mathrm{C}\left(157^{\circ} \mathrm{F}\right)$. The complete transition temperature shift package on beltine WF-70 weld that includes the more conventional $41-\mathrm{J} \mathrm{CVN}$ transition temperatures and $\mathrm{T}_{0}$ reference temperatures is presented in Table 4.1. The comparison between $\Delta T_{0}$ and $\Delta T_{41,}$ at a fluence of $1.0 \times 10^{19}$ neutrons $/ \mathrm{cm}^{2}$ shows about $17^{\circ} \mathrm{C}$ less quasi-static fracture toughness shift than the dynamic $41-\mathrm{J}$ CVN shift. The result at a fluence of $0.5 \times 10^{19}$ neutrons $/ \mathrm{cm}^{2}$ is opposite in comparison with the static shift larger by $24^{\circ} \mathrm{C}$. This discrepancy is probably a matter of chance more than a fundamental observation. Specifically, it is known that the scatter band of 41-J temperatures for duplicated CVN transition curves is of the order of $50^{\circ} \mathrm{C}$, and in the present case, the irradiated $41-J$ temperature was determined with only one transition temperature curve. 
TEST TEMPERATURE ( $\%$ )

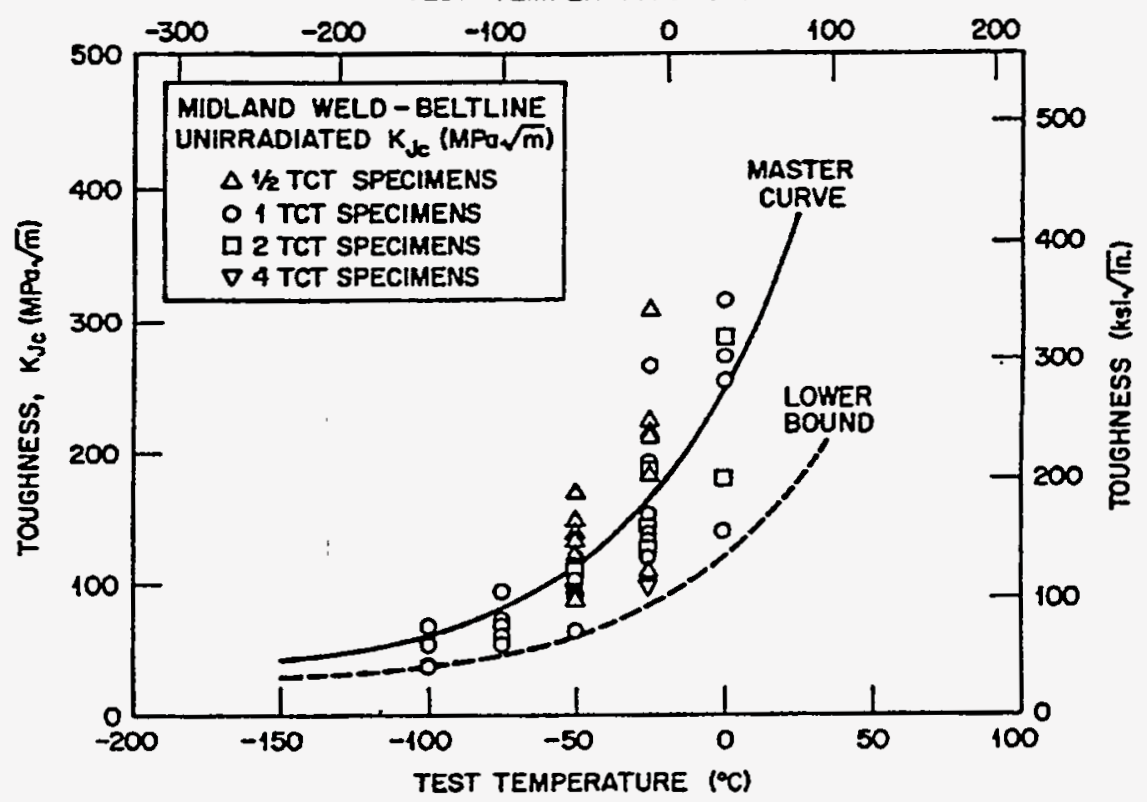

Figure 4.1. Master curve and $5 \%$ confidence limit curve (dashed) adjusted $10^{\circ} \mathrm{C}\left(18^{\circ} \mathrm{F}\right)$ for uncertainty in reference temperature, $T_{0}$.

ORNLDWO \&46599

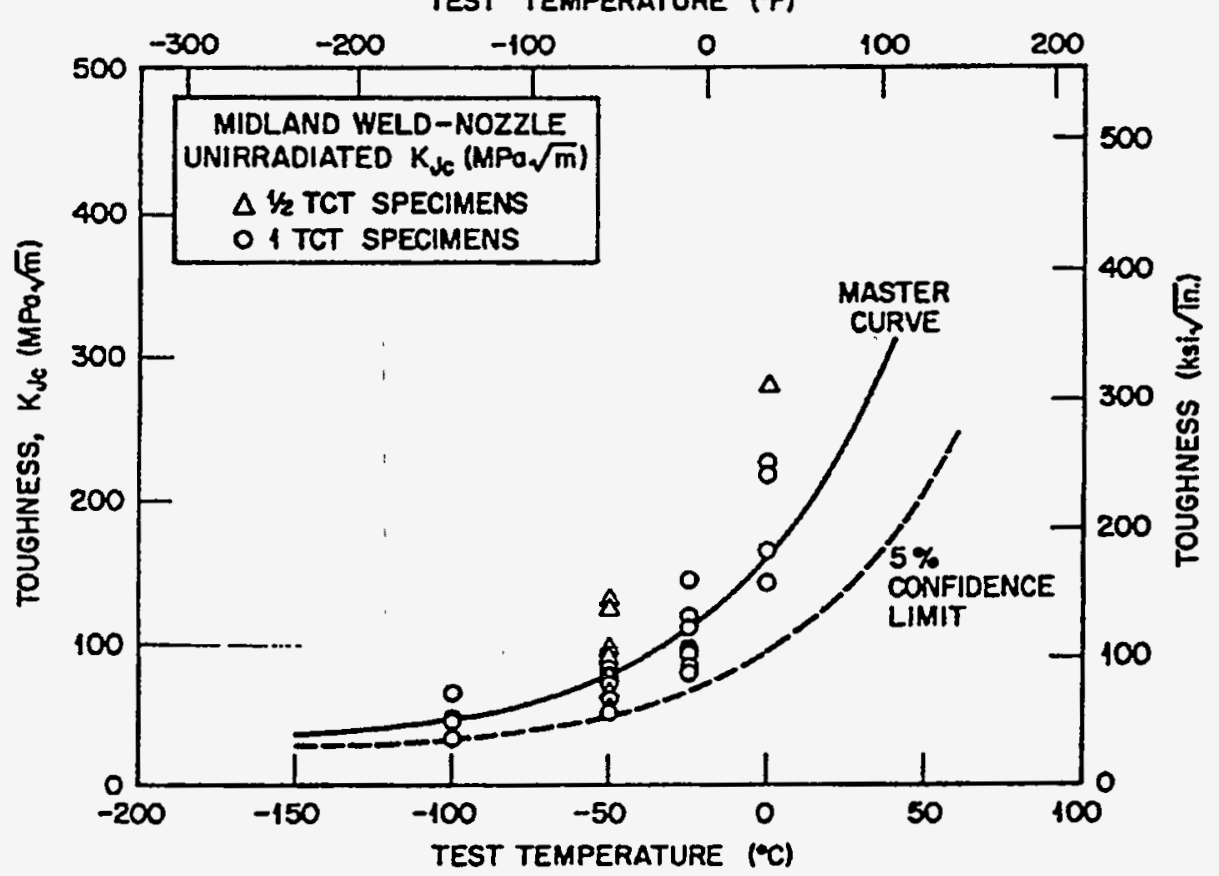

Figure 4.2. Transition temperature data for the Midland nozzle course weld WF-70 for two compact specimen sizes and a master curve on $1 T$ specimen size. 


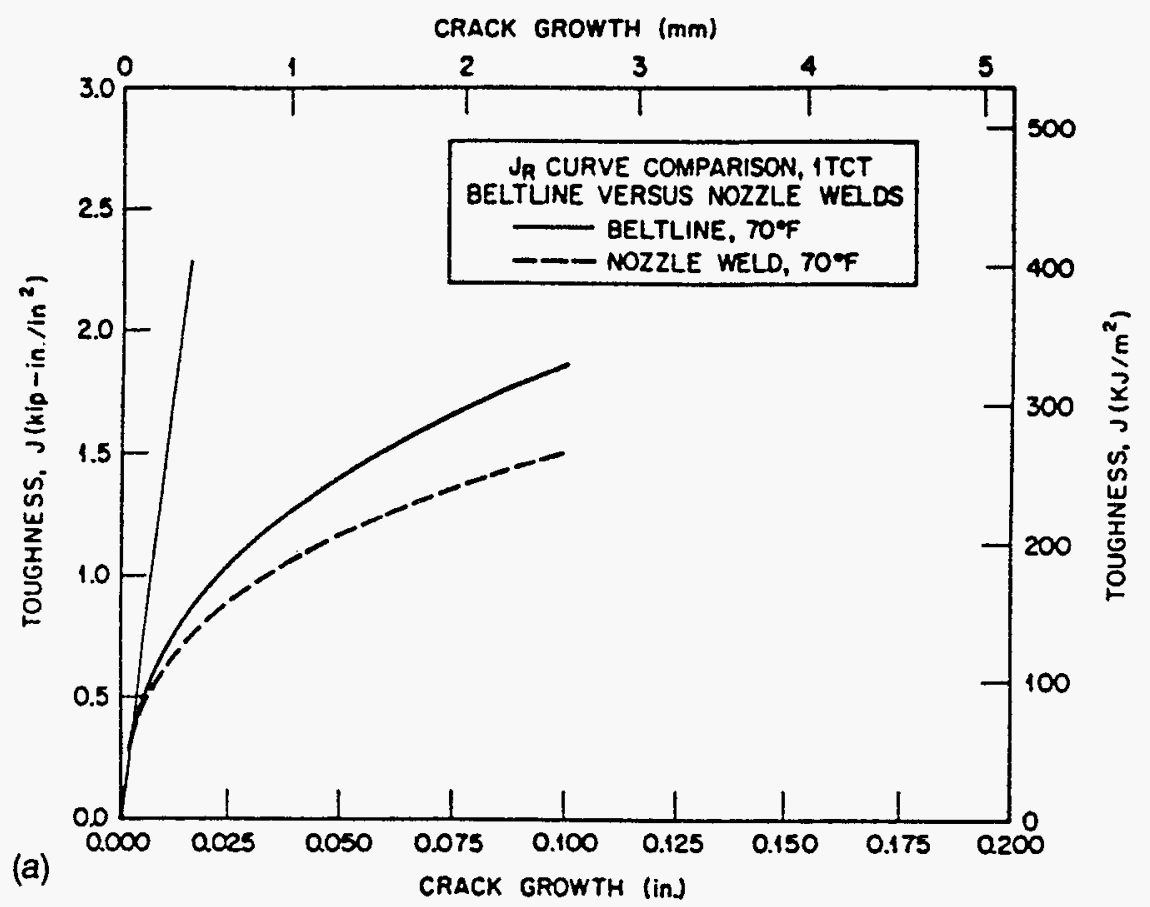

ORNL-DWG 93-13874

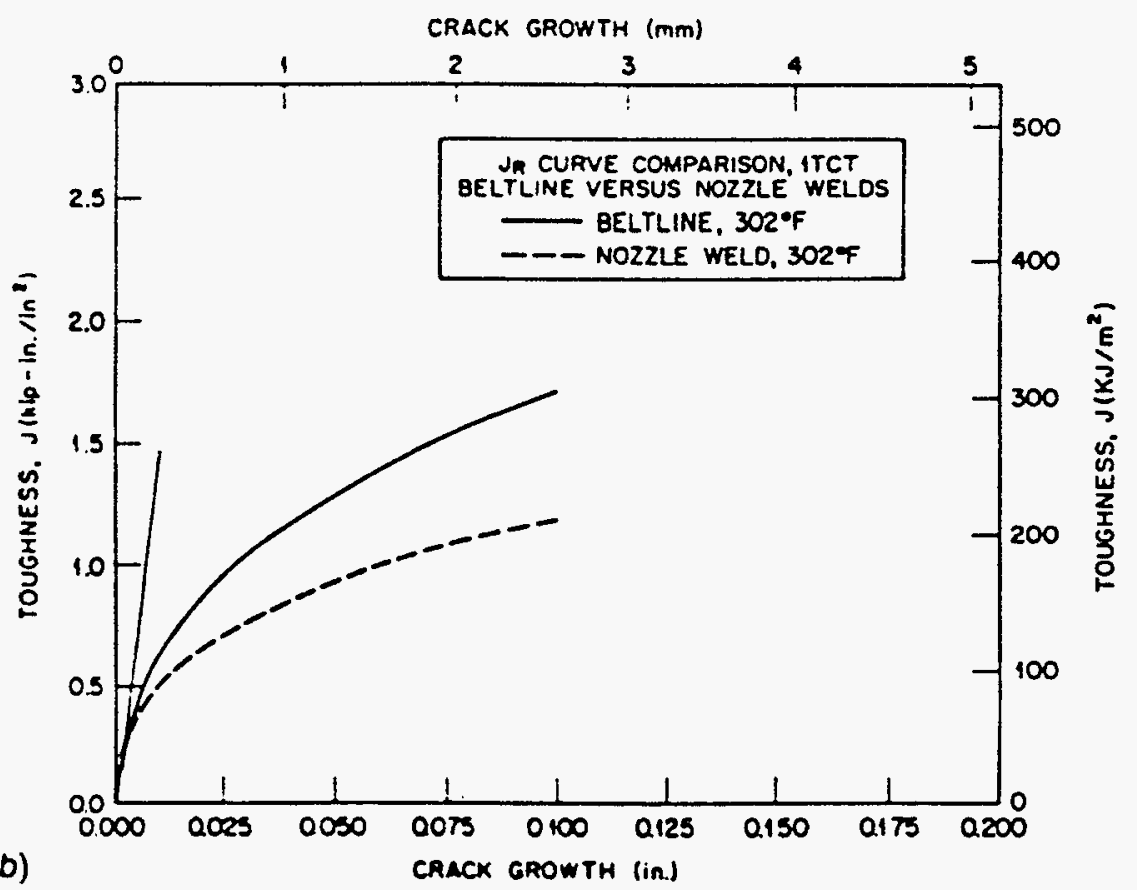

Figure 4.3. J-R curves that compare the nozzle versus the beltline weld metal ductile tearing resistance at (a) $21^{\circ} \mathrm{C}\left(70^{\circ} \mathrm{F}\right)$ and (b) $150^{\circ} \mathrm{C}$ $\left(302^{\circ} \mathrm{F}\right)$. 
ORNL-DWG 95-8162

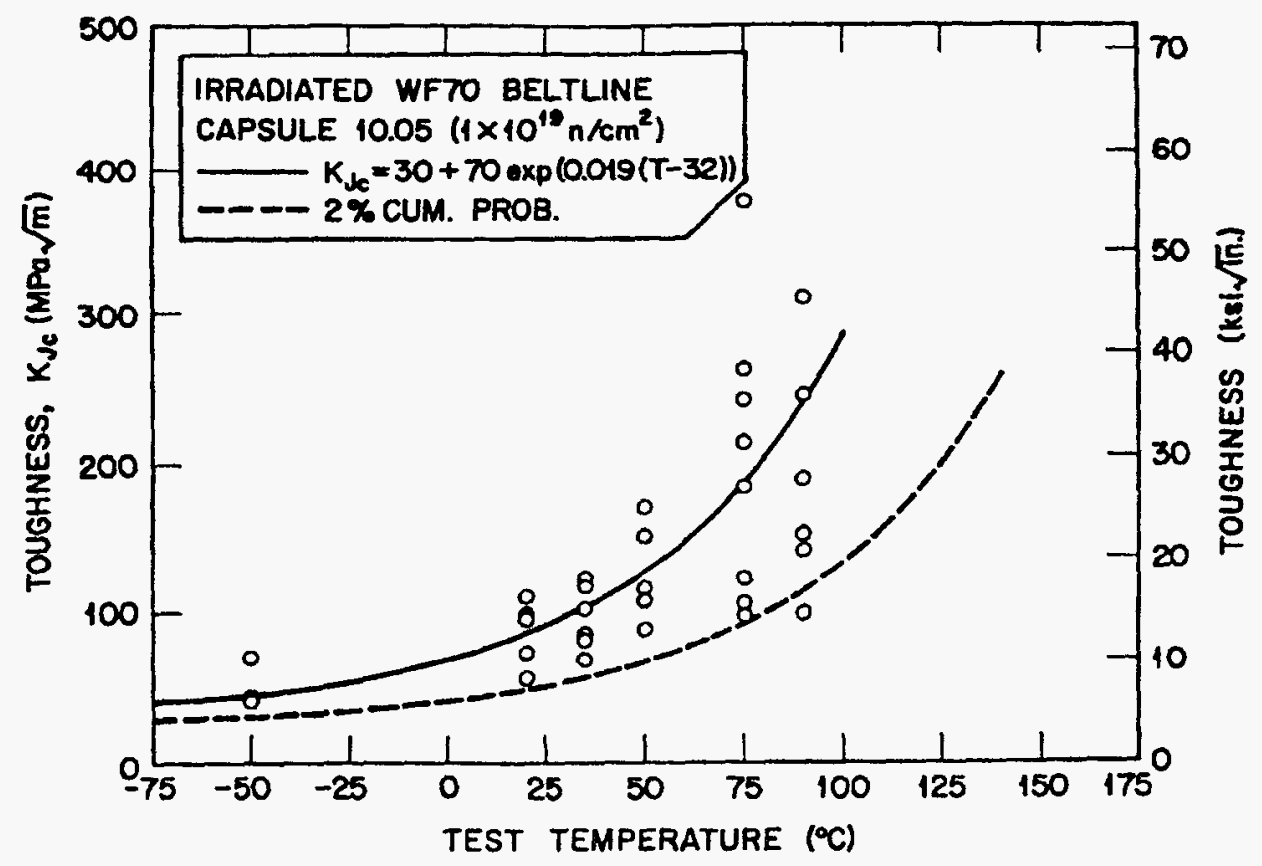

Figure 4.4. Master curve from specimens of capsule 10.05. All data were normalized to 1TC $(T)$ equivalence.

Table 4.1. Reference and transition temperature shifts for Midland WF-70 beltline weld

\begin{tabular}{|c|c|c|c|c|c|c|c|c|}
\hline \multirow{3}{*}{ Condition } & \multirow{2}{*}{\multicolumn{2}{|c|}{$T_{0}$}} & \multirow{2}{*}{\multicolumn{2}{|c|}{$T_{415}$}} & \multicolumn{4}{|c|}{ Curve shift } \\
\hline & & & & & \multicolumn{2}{|c|}{$\Delta T_{0}$} & \multicolumn{2}{|c|}{$\Delta T_{410}$} \\
\hline & $\left({ }^{\circ} \mathrm{C}\right)$ & $\left({ }^{\circ} \mathrm{F}\right)$ & $\left({ }^{\circ} \mathrm{C}\right)$ & $\left({ }^{\circ} \mathrm{F}\right)$ & $\left({ }^{\circ} \mathrm{C}\right)$ & $\left({ }^{\circ} \mathrm{F}\right)$ & $\left({ }^{\circ} \mathrm{C}\right)$ & $\left({ }^{\circ} \mathrm{F}\right)$ \\
\hline Unirradiated & -55 & -67 & -9.3 & 15.2 & & & & \\
\hline $0.5 \times 10^{19}$ neutrons $/ \mathrm{cm}^{2}$ & 14 & 26 & 35.6 & 96 & 69 & 139 & 45 & 81 \\
\hline $1.0 \times 10^{19}$ neutrons $/ \mathrm{cm}^{2}$ & 32 & 90 & 94.4 & 202 & 87 & 157 & 104 & 87 \\
\hline
\end{tabular}

There has been some interest in applying fracture mechanics test practices to specimens that have been exposed in surveillance capsules of commercial power-producing nuclear reactors. The most common specimen is the CVN specimen. When precracked and tested in three-point bend, there is a possibility that the $T_{0}$ reference temperature can be determined. The test temperature must be carefully selected, however.

A special fixture has been built for testing precracked Charpy specimens in the hot cells. It has the high-precision capability that is needed to test small specimens. A set of nine precracked Charpy specimens of unirradiated beltline weld WF-70 were tested at $-60^{\circ} \mathrm{C}\left(-76^{\circ} \mathrm{F}\right)$. These data are plotted in Figure 4.5 in Weibull coordinates. The $T_{0}$ temperature was $-54^{\circ} \mathrm{C}$ (using a data censoring and data ranking procedure). Ten precracked Charpy specimens irradiated in capsule $10.05\left(1 \times 10^{19}\right.$ neutrons $\left./ \mathrm{cm}^{2}\right)$ gave a $T_{0}$ temperature of $37^{\circ} \mathrm{C}$ (see Figure 4.6), resulting in a $\Delta T_{0}$ of $91^{\circ} \mathrm{C}$, very close to the $\Delta T_{0}$ of $87^{\circ} \mathrm{C}$ determined from $1 T C(T)$ specimens. These $T_{0}$ values can be compared to the values reported in Table 4.1. 


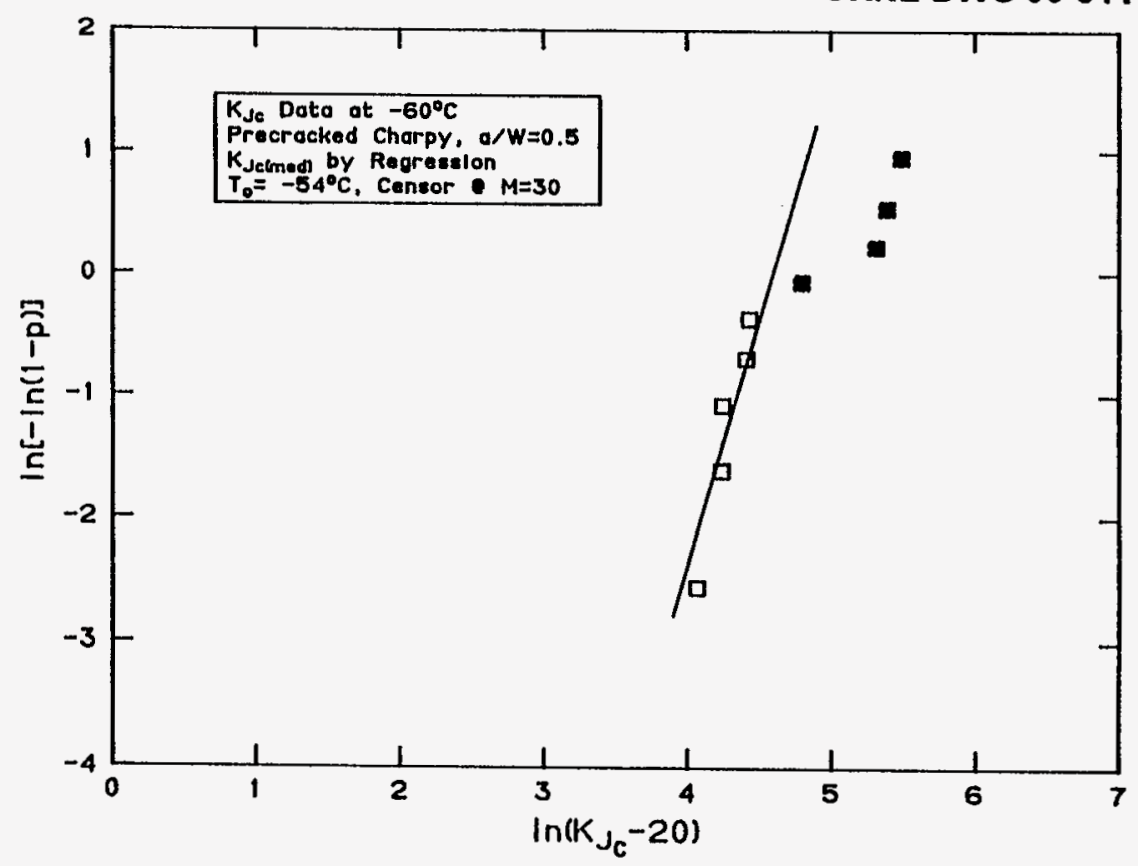

Figure 4.5 $\mathrm{K}_{\mathrm{Je}}$ data on unirradiated Midland beltline weld metal. Four precracked Charpy specimens (filled squares) gave invalid $\mathrm{K}_{\mathrm{Je}}$ values.

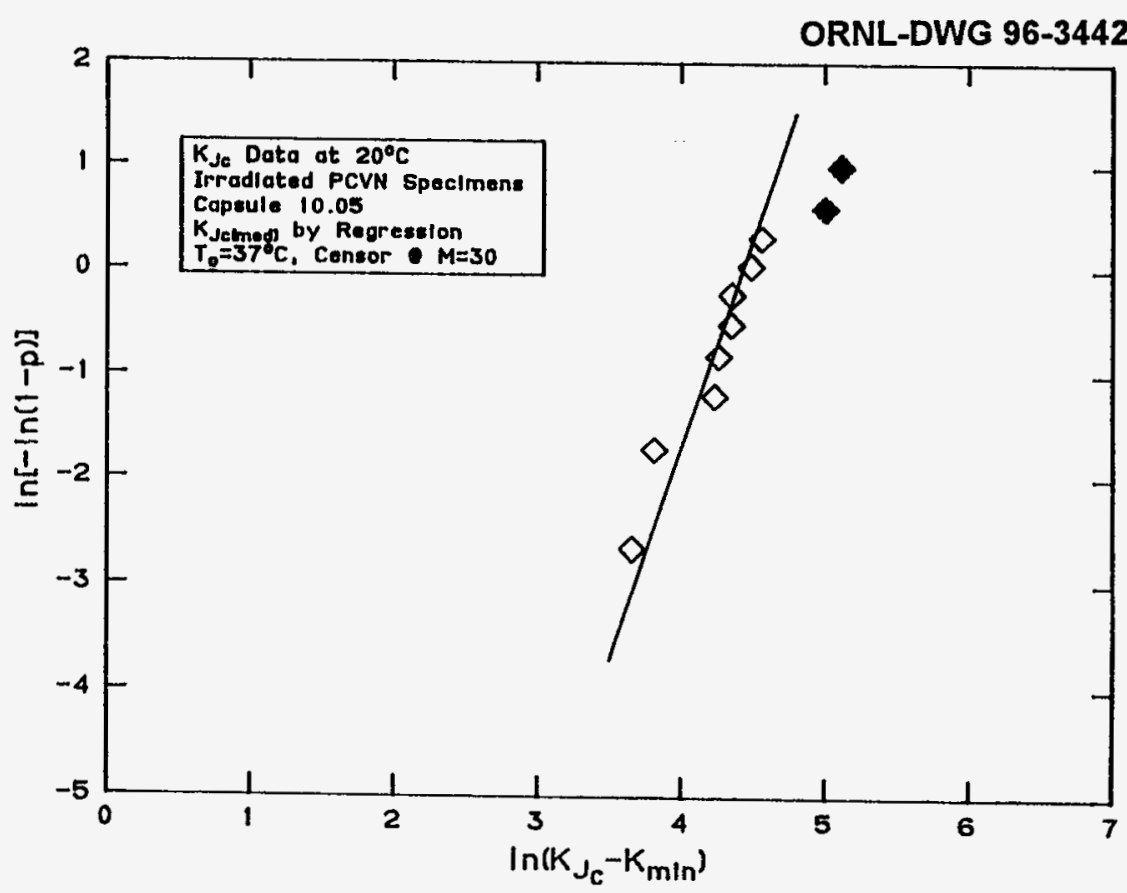

Figure 4.6. $\mathrm{K}_{\mathrm{Jc}}$ data on irradiated Midland beltline weld metal. Two precracked Charpy specimens (filled diamonds) gave invalid $K_{\mathfrak{J c}}$ values. 


\subsection{Crack-Arrest Toughness of WF-70 Weld Metal Specimens}

Thity weld-embrittled and six duplex crack-arrest specimens were prepared from the Midland WF-70 belline weld metal. Fifteen of the weld-embrittled specimens have been irradiated and are now available for testing. The results of tests on all the unirradiated specimens, including the six duplex specimens, are given below. The six duplex specimens were manufactured and tested to obtain toughness values at higher temperatures than are possible with the weld-embrittled specimens, thus enabling a better comparison to the irradiated specimens.

Preliminary results from tests on weld-embrittled crack-arrest specimens have been previously reported..$^{5}$ In preparing the brittle crack-starter bead for the weld-embrittled crack-arrest specimens, the McKay DWT stick electrode was used. The experience with these weld electrodes was not satisfactory, as it is believed that the HAZ created by these electrodes may be too tough to allow for crack propagation. Considerable tearing through that zone had occurred before a fast-running crack could initiate. Moreover, it appears that the specimen size may have been too small. As a result, the crack jumps, as well as the remaining ligaments in most of the specimens, were too small to satisfy the validity criteria of the ASTM "Standard Test Method for Determining Plane-Strain CrackArrest Fracture Toughness, $K_{\mathrm{t}}$, of Ferritic Steels" (E 1221-88). Nevertheless, it is believed that the results are useful since $E$ 1221-88 may be too restrictive. It was decided to prepare more duplex-type specimens that could be tested with better crack-initiation control at temperatures higher than those possible using weld-embrittled specimens.

The crack-arrest toughnesses of all the specimens are given in Table 4.2 and have been plotted as a function of temperature in Figure 4.7. Table 4.2 gives the crack-arrest toughness, $\mathrm{K}_{\mathrm{a}}$, calculated using the expression in the present standard as well as the one proposed for the upcoming revision. The arrested fractional crack depth, $a_{2} N$, has also been given since, as will be shown later, the difference between the present expression for $K_{a}$ and the proposed method depends upon the $a_{\mathbf{z}} \mathbf{W}$.

According to $E 1221-88$, for the measured value of crack-arrest toughness, $K_{2}$, to qualify as a plane-strain fracture toughness, $K_{b}$, it must meet five validity criteria. These criteria are given in Table 4.2 for each $K_{a}$ as a ratio, so that a value greater than one indicates that the criterion has been met. These five criteria have been labeled with the same letters as those used in $E$ 1221-88. The values of $K_{2}$ used in evaluating the validity criteria have been calculated using the proposed expression. As will be presented below, the differences between the present and proposed expressions vary between 0 and $7 \%$. It may be seen in Table 4.2 that $7 \%$ will not change the validity for any one specimen since at least one of the validity ratios is either greater than or less than one by significantly more than $7 \%$. The $K_{1}$ values for two specimens, MW15JC and MW15JEr1, are "valid" according to all five ASTM plane strain criteria, and they seem to be in the same population as the invalid values.

The data points in Figure 4.7 have been labeled with the specimen identifications to facilitate reference to Table 4.2 to determine which of the five validity criteria have been met. The data were also analyzed by examining the relation of the data point with respect to various curves all based on the ASME $K_{\mathrm{la}}$ equation, and are of the form:

$$
\mathrm{K}_{2}=29.4+13.675 \exp [0.0261(\mathrm{~T}-\mathrm{A})] \text {, }
$$

where $A$ can be $T_{M}, T_{L B}, N D T$, or $R T_{N D T}$, and $T$ is the temperature in ${ }^{\circ} \mathrm{C}$. The value of the parameter $T_{M}$ is obtained by regression fitting Equation (4.1) to the data, in which case the resulting curve is a mean curve in the leastsquares sense. Equation (4.1), when fit to the data, resulted in a value of $T_{M}=-70.5^{\circ} \mathrm{C}$. A lower-bound curve is obtained by shifting the curve defined by Equation (4.1) to higher temperatures, until it passes through the last data point encountered. The last data point was for specimen MW15IAB, and the lower-bound curve, when placed through it, resulted in $T_{L B}=-56.1^{\circ} \mathrm{C}$.

It is instructive to evaluate for this LUS material the values of the DWT-NDT and the reference temperature, $R T_{\text {NDT, }}$, since a range of values that depend upon the depth in the weld and azimuthal location have been measured.

Reference 1, Tables 1 through 6, gives values of NDT ranging from -60 to -40 , and in Table 13, the values of $\mathrm{RT}_{\mathrm{NDT}}$ ranged from -20 to $+37^{\circ} \mathrm{C}$. ASME $K_{\mathrm{t}}$ curves using these four values have been plotted in Figure 4.8 . The concept of $R T_{\text {NOT }}$ is based on using both the NDT and Charpy data, and in the case of this low-USE weld, the value 
Table 4.2. Crack-arrest toughness, $K_{2}$, of Midland WF-70 submerged-arc weld metal specimens (specimens are oriented so that crack propagation is in the welding direction)

\begin{tabular}{|c|c|c|c|c|c|c|c|c|c|c|c|}
\hline \multirow{2}{*}{ Specimen } & \multirow{2}{*}{$\begin{array}{l}\text { Thickness } \\
\text { (mm) }\end{array}$} & \multirow{2}{*}{$\begin{array}{c}\text { Test } \\
\text { temperature } \\
\left({ }^{\circ} \mathrm{C}\right)\end{array}$} & \multirow{2}{*}{$\begin{array}{c}\text { Arrested } \\
\text { crack } \\
\text { depth } \\
\left(a_{2} M\right)\end{array}$} & \multicolumn{2}{|c|}{$\begin{array}{c}\mathrm{K}_{\mathrm{a}} \text { calculated using: } \\
(\mathrm{MPa} \sqrt{\mathrm{m}})\end{array}$} & \multicolumn{5}{|c|}{ If $\geq 1$, respective criterion is met:" } & \multirow{2}{*}{$\begin{array}{c}\text { Invalid } \\
\text { according } \\
\text { to } \\
\text { criteria }\end{array}$} \\
\hline & & & & $\begin{array}{l}\text { Present } \\
\text { standard }\end{array}$ & $\begin{array}{l}\text { Proposed } \\
\text { standard }\end{array}$ & A & $\mathbf{B}$ & C & D & $\mathbf{E}$ & \\
\hline \multicolumn{12}{|c|}{ Weld-embrittled specimens (W = $104.2 \mathrm{~mm})$} \\
\hline $\begin{array}{l}\text { MW15IAB } \\
\text { MW12A1B } \\
\text { MW12EBB } \\
\text { MW12A1 } \\
\text { MW12D1A } \\
\text { NW12HBB } \\
\text { MW12EAB } \\
\text { MW12GBB } \\
\text { MW12GAB } \\
\text { MW15HAA } \\
\text { MW12FBB } \\
\text { 14DRW34 } \\
\text { MW12HBA } \\
\text { MW12HAA }\end{array}$ & $\begin{array}{l}33.0 \\
25.4 \\
33.0 \\
33.1 \\
33.0 \\
33.0 \\
33.0 \\
33.0 \\
33.0 \\
25.4 \\
33.0 \\
33.0 \\
25.4 \\
25.4\end{array}$ & $\begin{array}{r}-40.0 \\
-40.0 \\
-40.0 \\
-30.0 \\
-30.0 \\
-30.0 \\
-30.0 \\
-25.0 \\
-25.0 \\
-20.0 \\
-20.0 \\
-10.0 \\
1.0 \\
10.0\end{array}$ & $\begin{array}{l}0.951 \\
0.909 \\
0.926 \\
0.956 \\
0.927 \\
0.868 \\
0.887 \\
0.933 \\
0.858 \\
0.862 \\
0.866 \\
0.891 \\
0.890 \\
0.860\end{array}$ & $\begin{array}{r}47.8 \\
58.5 \\
75.3 \\
76.3 \\
77.7 \\
91.8 \\
93.0 \\
77.5 \\
92.9 \\
101.1 \\
148.4 \\
107.5 \\
90.0 \\
137.7\end{array}$ & $\begin{array}{r}50.2 \\
62.3 \\
79.9 \\
80.1 \\
82.4 \\
98.4 \\
99.5 \\
82.0 \\
99.5 \\
108.3 \\
158.9 \\
114.8 \\
96.2 \\
147.6\end{array}$ & $\begin{array}{l}0.33 \\
0.61 \\
0.49 \\
0.29 \\
0.49 \\
0.88 \\
0.75 \\
0.44 \\
0.95 \\
0.92 \\
0.89 \\
0.73 \\
0.73 \\
0.93\end{array}$ & $\begin{array}{l}0.70 \\
0.85 \\
0.42 \\
0.24 \\
0.38 \\
0.48 \\
0.40 \\
0.34 \\
0.50 \\
0.40 \\
0.18 \\
0.28 \\
0.39 \\
0.21\end{array}$ & $\begin{array}{l}5.66 \\
2.83 \\
2.24 \\
2.17 \\
2.05 \\
1.44 \\
1.41 \\
2.04 \\
1.39 \\
0.89 \\
0.54 \\
1.01 \\
1.08 \\
0.45\end{array}$ & $\begin{array}{l}2.75 \\
2.54 \\
2.63 \\
2.77 \\
2.64 \\
2.36 \\
2.45 \\
2.67 \\
2.32 \\
2.34 \\
2.36 \\
2.47 \\
2.46 \\
2.32 \\
\end{array}$ & $\begin{array}{l}1.77 \\
1.22 \\
0.85 \\
0.86 \\
0.72 \\
0.72 \\
0.91 \\
0.97 \\
0.97 \\
0.91 \\
0.39 \\
0.76 \\
0.91 \\
0.67\end{array}$ & $\begin{array}{l}A, B \\
A, B \\
A, B, E \\
A, B, E \\
A, B, E \\
A, B, E \\
A, B, E \\
A, B \\
A, B \\
A, B, C, E \\
A, B, C, E \\
A, B, E \\
A, B, E \\
A, B, C, E\end{array}$ \\
\hline \multicolumn{12}{|c|}{ Duplex specimens $(\mathrm{W}=127 \mathrm{~mm})$} \\
\hline $\begin{array}{l}\text { MW15JC } \\
\text { MW15JBr } \\
\text { MW15JEr2 } \\
\text { MW15JEr1 } \\
\text { MW15JF } \\
\text { MW15JD } \\
\text { MW15JE } \\
\text { MW15JB } \\
\text { MW15JA }\end{array}$ & $\begin{array}{l}29.1 \\
33.0 \\
33.1 \\
33.1 \\
33.0 \\
33.0 \\
33.1 \\
33.0 \\
33.0\end{array}$ & $\begin{array}{r}-20.0 \\
-10.0 \\
-10.0 \\
0.0 \\
10.0 \\
10.0 \\
22.0 \\
24.0 \\
25.6\end{array}$ & $\begin{array}{l}0.849 \\
0.843 \\
0.883 \\
0.620 \\
0.647 \\
0.525 \\
0.448 \\
0.475 \\
0.550\end{array}$ & $\begin{array}{r}65.3 \\
81.1 \\
94.7 \\
105.3 \\
128.7 \\
172.4 \\
175.0 \\
187.6 \\
172.0\end{array}$ & $\begin{array}{r}70.0 \\
86.8 \\
101.3 \\
106.7 \\
131.6 \\
171.3 \\
174.7 \\
186.5 \\
171.3\end{array}$ & $\begin{array}{l}1.01 \\
1.05 \\
0.78 \\
2.54 \\
2.36 \\
3.16 \\
3.68 \\
3.50 \\
3.00\end{array}$ & $\begin{array}{l}1.29 \\
0.85 \\
0.47 \\
1.34 \\
0.80 \\
0.64 \\
0.70 \\
0.58 \\
0.59\end{array}$ & $\begin{array}{l}2.44 \\
1.76 \\
1.30 \\
1.15 \\
0.74 \\
0.44 \\
0.41 \\
0.36 \\
0.43\end{array}$ & $\begin{array}{l}4.52 \\
4.95 \\
5.68 \\
3.00 \\
2.91 \\
1.98 \\
1.27 \\
1.44 \\
2.06\end{array}$ & $\begin{array}{l}1.77 \\
1.13 \\
0.80 \\
1.21 \\
0.80 \\
0.42 \\
0.33 \\
0.32 \\
0.45 \\
\end{array}$ & $\begin{array}{l}\text { Valid } \\
B \\
A, B, E \\
\text { Valid } \\
B, C, E \\
B, C, E \\
B, C, E \\
B, C, E \\
B, C, E\end{array}$ \\
\hline $\begin{array}{l}\text { - The letters co } \\
\text { length. The e } \\
\text { One or more } \\
\end{array}$ & a specimen ir & lat the lest resu & $\begin{array}{l}\text { are summar } \\
\text { standard was } \\
\text { I not meet one }\end{array}$ & $\begin{array}{l}\text { zed as follows: } \\
\text { used. } \\
\text { of the minimum }\end{array}$ & $\begin{array}{l}A, B=\text { remainir } \\
\text { lengths of the }\end{array}$ & $\begin{array}{l}\text { tent to } \\
\text { E } 122\end{array}$ & $C=$ & men tox & & sufficlen & crack jump \\
\hline
\end{tabular}




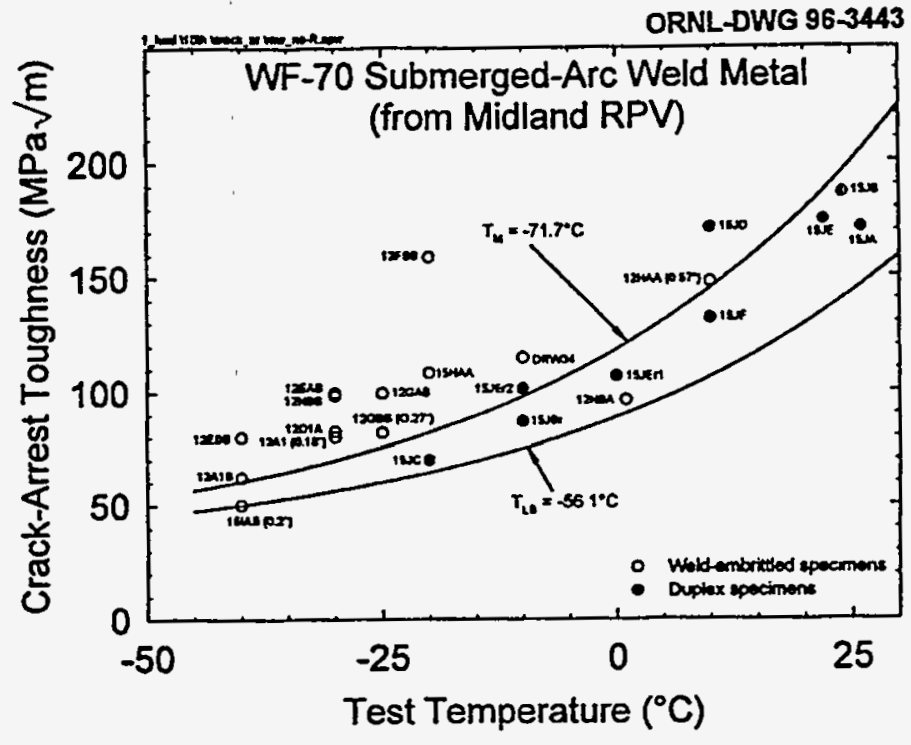

Figure 4.7. Crack-arrest toughness, $K_{a}$, of specimens machined from submerged arc-welds of Midland reactor pressure vessels, as well as a mean and lower-bound toughness curve (specimens are oriented so that crack propagation is in the welding direction).

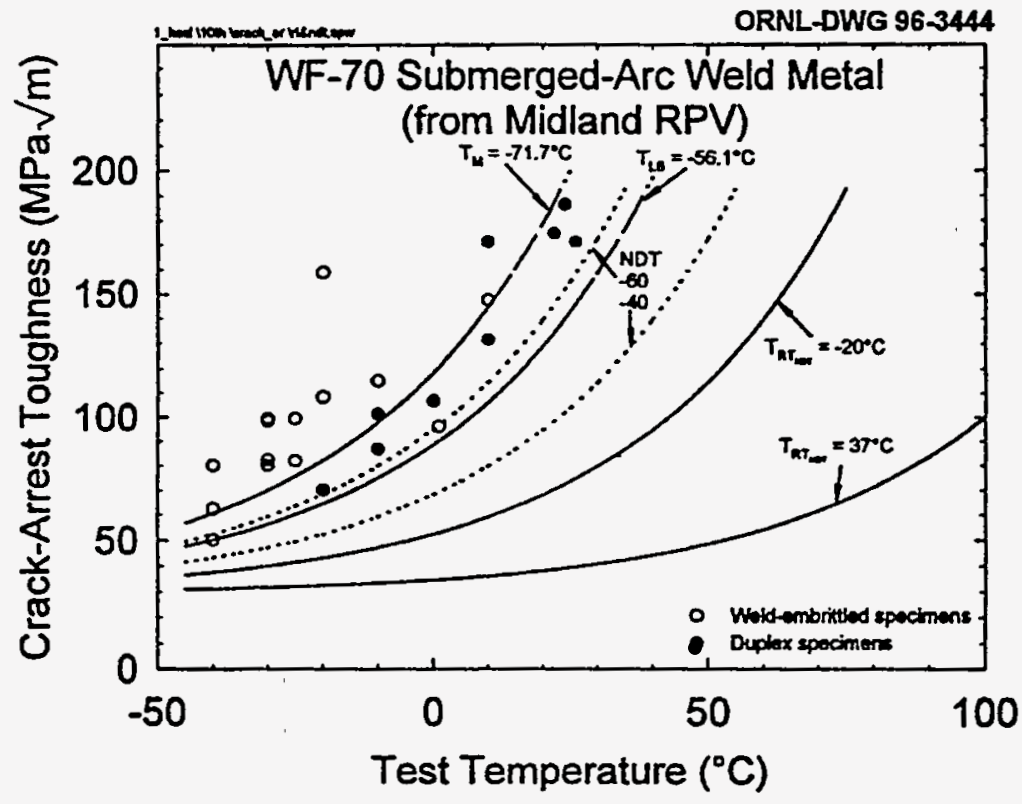

Figure 4.8. Crack-arrest toughness, $K_{a}$ of specimens machined from submerged-arc welds of Midland reactor pressure vessels showing a mean, lower-bound, and two bounding ASME Ka curves. 
of $R T_{\text {NDT }}$ was dictated by the Charpy results. The procedure for the determination of $R T_{\text {NDT }}$ in Subarticle NB-2330 of the 1994 Edition of the ASME Boiler and Pressure Vessel Code, Section III, in the case when a full CVN curve has to be used to determine the temperature at which $68 \mathrm{~J}(50 \mathrm{ft}-\mathrm{lb})$ is attained, is not unambiguous. The method used in reference 1 was to fit a curve through the minimum of the Charpy data of each set of data points. The value of $\mathrm{RT}_{\text {NDT }}$ was also determined using other possible interpretations of NB-2330, but the range of values reported here was obtained using the minimum curve fit. The $\mathrm{K}_{\mathrm{a}}$ data in Figure 4.8 appear to correlate better with ASME $\mathrm{K}_{\mathrm{ta}}$ curves that are based on values of DWT-NDT than with $R T_{\text {NDT }}$. This is not necessarily surprising, since the DWT test is actually a crack-arrest test.

The percent difference between $K_{2}$ values as a function of arrested crack depth, $a_{d} W$, was calculated using the expression in the present $E$ 1221-88 standard, as well as the one for the proposed revision, and the results are shown in Figure 4.9. The value of $a_{2} W$ for the crack-arrest specimens tested varied from a minimum of 0.448 for specimen MW15JE to a maximum of 0.956 for specimen MW12A1, with an average of 0.801 for all the specimens. It may be seen that, over the range of the $a_{2} N$ for the Midland specimens, the proposed expression will result in a maximum increase in the calculated value of $\mathrm{K}_{\mathbf{z}}$ of about $7 \%$.

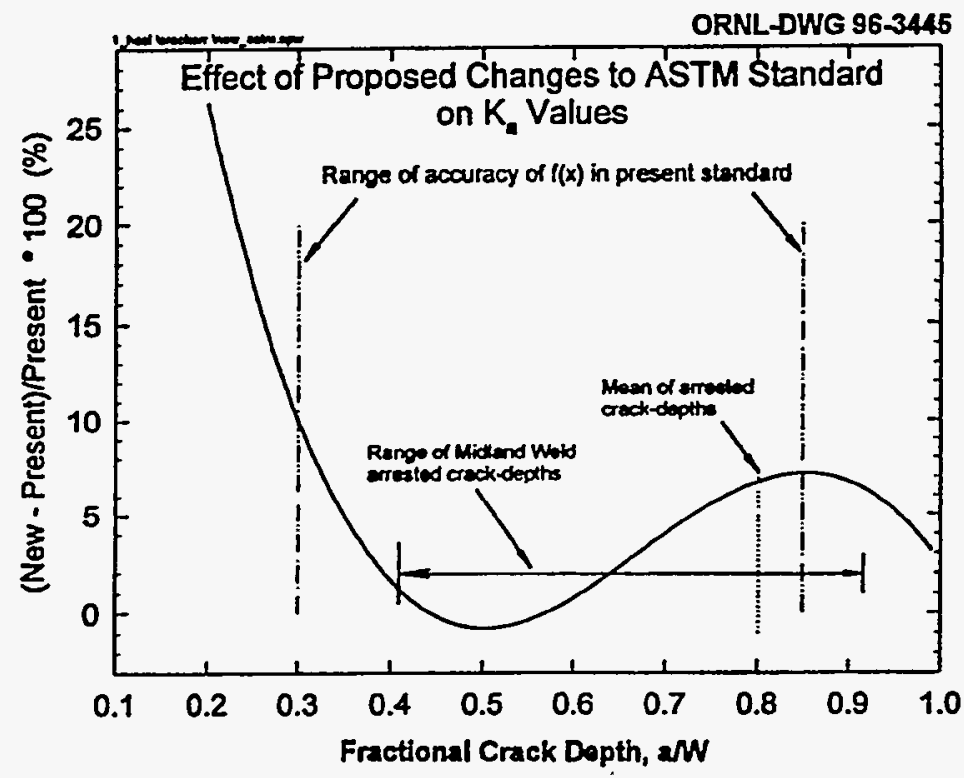

Figure 4.9. Percent change of $\mathrm{K}_{\mathrm{a}}$ due to the proposed change in the present ASTM E 1221 as a function of crack depth.

Tests with the duplex-type crack-arrest specimens did indeed increase the test temperatures at which toughness values were obtained. Relative to the results from weld-embrittled specimens, the highest test temperature increased from 10 to $26^{\circ} \mathrm{C}$, while the highest measured $\mathrm{K}_{2}$ increased from 148 to $187 \mathrm{MPa} / \mathrm{m}$.

\section{References}

1. R. K. Nanstad, D. E. McCabe, R. L. Swain, and M. K. Miller, Martin Marietta Energy Systems, Inc., Oak Ridge Natl. Lab., Chemical Composition and $R T_{\text {NDT }}$ Determinations for Midland WF-70, USNRC Report NUREG/CR-5914 (ORNL/TM-6740), December 1992.*

2. D. E. McCabe, R. K. Nanstad, S. K. Iskander, and R. L. Swain, Martin Marietta Energy Systems, Inc., Oak Ridge Natl. Lab., Unirradiated Material Properties of Midland Weld WF-70, USNRC Report NUREG/CR-6249 (ORNLTM-12777), October 1994.* 
3. D. E. McCabe, M. A. Sokolov, R. K. Nanstad, and R. L. Swain, Martin Marietta Energy Systems, Inc., Oak Ridge Natl. Lab., Effects of Irradiation to 0.5 and $1.0 \times 10^{19}$ neutrons $/ \mathrm{cm}^{2}(>1 \mathrm{MeV}$ on the Midland Reactor Low UpperShelf Weld: Capsules 10.01,10.02, and 10.05 in the Heavy-Section Steel Irradiation Program Tenth Irradiation Series, USNRC Report ORNLNRC/LTR-95/18, September 1995.*

4. M. A. Sokolov and D. E. McCabe, Martin Marietta Energy Systems, Inc., Oak Ridge Natl. Lab., Comparison of Irradiation-Induced Shitts of $K_{t}$ and Charpy Curves: Analysis of Heavy-Section Steel Irradiation Program Data, USNRC Report ORNL/NRC/LTR-95/4, June 1995.*

5. D. E. McCabe and S: K. Iskander, Martin Marietta Energy Systems, Inc., Oak Ridge Natl. Lab., "Irradiation Effects in a Commercial LUS Weld," pp. 15-17 in Heavy-Section Steel Irradiation Program Semiannual Progress Report April-September 1993, USNRC Report NUREG/CR-5591, Vol. 4, No. 2 (ORNLTM-11568N4\&N2), March 1995."

Available for purchase from National Technical Information Service, Springfield, VA 22161. 


\title{
5. Irradiation Effects on Weld Heat-Affected Zone and Plate Materials (Series 11)
}

\author{
R. K. Nanstad and D. E. McCabe
}

The purpose of this task is to examine the effects of neutron irradiation on the fracture toughness (ductile and brittle) of the HAZ of welds and of A 302 grade B (A302B) plate materials typical of those used in fabricating older RPVs. The initial plate material of emphasis will be $A 302 B$ steel, not the A302B modified with nickel additions. This decision was made by NRC following a survey of the materials of construction for RPVs in operating U.S. nuclear plants. Reference 1 was used for the preliminary survey, and the information from that report was revised by NRC staff based on information contained in the licensee responses to Generic Letter (GL) 92-01, "Reactor Vessel Structural Integrity, 10 CFR 50.54(f)." The resulting survey showed a total of eight RPVs with A302B, ten with A302B (modified), and one with A302 grade A plate. Table 5.1 in the previous semiannual report ${ }^{2}$ provides a summary of that survey. For the HAZ portion of the program, the intent is to examine HAZ material in the $A 302 B$ (i.e., with low nickel content), and in A302B (modified) or A533B-1 (i.e., with medium nickel content).

\section{References}

1. American Society of Mechanical Engineers Section XI Task Group on Reactor Vessel Integrity Requirements, White Paper on Reector Vessel Integrity Requirements for Level A and B Conditions, EPRI TR-100251, Electric Power Research Institute, Palo Alto, California, January 1993.*

2. R. K. Nanstad and D. E. McCabe, Martin Marietta Energy Systems, Inc., Oak Ridge Natl. Lab., "Irradiation Effects on Weld Heat-Affected Zone and Plate Materials (Series 11)," in Heavy-Section Steel Irradiation Program Semiannual Progress Report April - September 1994, USNRC Report NUREG/CR-5591, Vol. 5, No. 2 (ORNLTM-11568N5\&N2), 1995.†

"Available in public technical libraries.

†Available for purchase from National Technical Information Service, Springfield, VA 22161. 


\title{
6. Annealing Effects in Low Upper-Shelf Welds \\ (Series 9)
}

\author{
S. K. Iskander
}

\subsection{Introduction}

The purpose of the Ninth Irradiation Series is to evaluate the correlation between fracture toughness and CVN impact energy during irradiation, annealing, and reirradiation (IAR). The activities in this reporting period have concentrated on the preparation of equipment and components necessary for in situ IAR at two locations on the East side of the $U$. of M. FNR. The facilities consist of equipment to hold the capsules containing the specimens to be irradiated, to maintain uniform and constant temperatures during irradiation, as well as to anneal the specimens. Before capsule irradiation can begin, dosimetry and temperature verification tests must be completed. The design of a reusable capsule capable of reirradiating IAR CVN and 1TC (T) specimens is also progressing. The data acquisition and control system (DACS) for the first two IAR facilities is complete and awaiting completion of the IAR facilities and temperature test capsule for checkout and control algorithm development.

\subsection{Design, Fabrication, and Installation of New Irradiation Facilities (1. I. Siman-Tov, D. W. Heatherly, C. A. Baldwin, D. W. Sparks, and G. E. Giles, Jr.)}

During this reporting period, two IAR facilities were fabricated and assembled. They have been delivered to ORNL for final leak and electrical tests, as well as tests on the heater connectors to the instrumentation. The two facilities will first be tested at ORNL with the temperature verification capsule before they are shipped to the FNR.

A reusable temperature verification capsule is presently being fabricated, and surrogate test specimens for this capsule have already been machined. The temperature verification capsule will contain 24 thermocouples (TCs) for control and recording of specimen temperatures. A dosimeter capsule has also been fabricated and is ready to be used in the dosimetry verification at the FNR. All of the dosimeters for the first two experiments have been fabricated. The design of the dosimeter verification capsule is described below. A purchase order has also been awarded for the fabrication of two sets of IAR capsule parts. These parts will be used to assemble the first two capsules of specimens to be irradiated.

Both the temperature and dosimetry verification capsules were designed to be reusable and will be used at all positions on the East face of the reactor, as well as on the South face when the latter facilities are completed. This capsule will be used in all positions on the East face and on the South side facilities when these become available.

\subsection{Design of the Dosimetry Capsule (C. A. Baldwin)}

The HSSI Program irradiated two of its Tenth Series metallurgical capsules in a facility located on the East face of the FNR. Prior to the irradiations, a dosimetry experiment was carried out to measure the neutron fluence rates, spectral characteristics, and gradients for a typical Tenth Series capsule design.* This facility is scheduled to be replaced in the near future with three smaller facilities that will occupy roughly the same location. Two of the new facilities are designed to hold metallurgical capsules for the HSSI Program, and the third will be for metallurgical capsules of the University of California at Santa Barbara (UCSB). Due to significant changes in the geometry and material composition of the East face region, it is essential to perform new measurements and calculations of the neutron fluence rates and gradients prior to starting irradiation. To accomplish this task a reusable dosimetry capsule has been designed and fabricated. Figure 6.1 illustrates the dosimetry capsule and shows the arrangement of internal parts. The capsule closely resembles a metallurgical capsule in both size and material

"I. Remec, C. A. Baldwin, and F. B. K. Kam, Neutron Exposure Parameters for the Dosimetry Capsulo in the Heavy-Section Steol Irradiation Program Tenth Irradiation Series, draft NUREG report in preparation. 
composition. The principal difference is the use of stainless steel parts for the dosimetry capsule as opposed to carbon steel specimens in a metallurgical capsule. This substitution was necessary because the reusable dosimetry capsule will be exposed to reactor pool water for extended periods of time in the FNR facilities. After the first verification experiment, the dosimetry capsule will be unloaded and reloaded remotely in the hot cell at the FNR for use in other positions. Provisions to simplify this task, such as a spring-loaded top latch and removable dosimetry blocks, have been incorporated into the design.
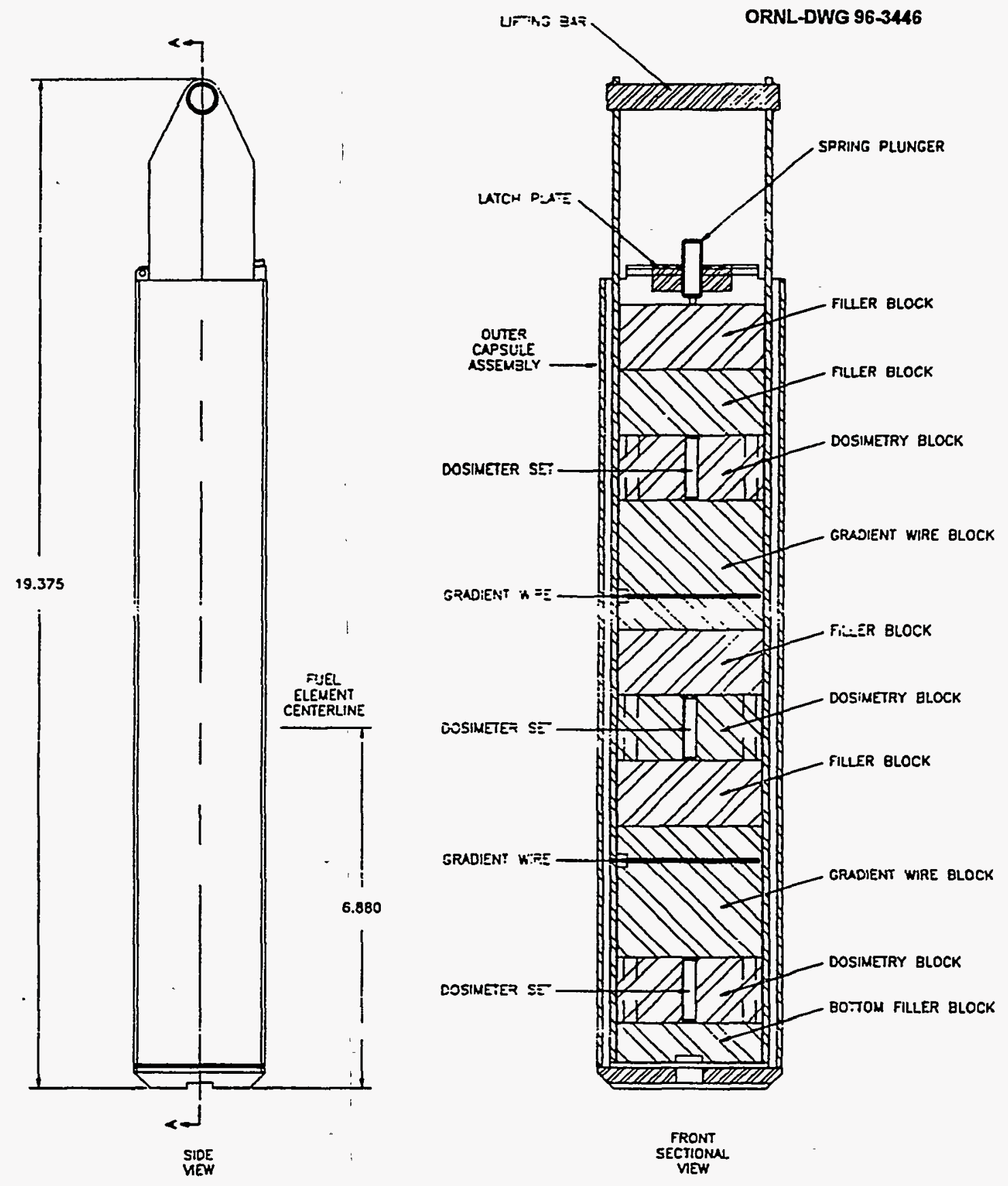

Figure 6.1. Dosimetry verification capsule for the East and South side facilities of the University of Michigan Ford Nuclear Reactor.

Dosimetry for the verification experiments will consist of radiometric dosimeter sets, fission/radiometric dosimeter sets, and iron gradient wires. The radiometric dosimeter sets contain $0.1 \% \mathrm{Co} / \mathrm{Al}, \mathrm{Ni}, \mathrm{Fe}, \mathrm{Ti}$, and $\mathrm{Cu}$ wires encapsulated in welded aluminum cans. The fission/radiometric dosimeter sets contain $0.1 \% \mathrm{Co} / \mathrm{Al}, \mathrm{Ni}, \mathrm{Fe}, \mathrm{Ti}, \mathrm{Cu}$, 
${ }^{238} \mathrm{UO}_{2}$, and ${ }^{237} \mathrm{NpO}_{2}$ wires covered in gadolinium thermal neutron shields and encapsulated in welded stainless steel cans. Two fission/radiometric dosimeter sets and 13 radiometric dosimeter sets will be loaded for each verification experiment.

In addition to the two HSSI facilities on the East face of the reactor, two more are planned for the South face of the reactor. No measurements have been made on the South face; characterization experiments will be necessary to predict accurate irradiation times to meet fluence requirements. The dosimetry verification capsule will be reused to make these measurements when needed.

\subsection{Data Acquisition and Control System (M. T. Hurst)}

The DACS instrumentation for the first two IAR facilities is essentially complete and awaiting completion of the IAR facilities and temperature test capsule for checkout and control algorithm development. A brief description of the DACS has been previously reported.'

\section{Reference}

1. S. K. Iskander and R. K. Nanstad, Martin Marietta Energy Systems, Inc., Oak Ridge Natl. Lab., "Annealing Effects in Low Upper-Shelf Welds," in Heavy-Section Steel Imadiation Program Semiannual Progress Report October 1994-March 1995, USNRC Report NUREG/CR-5591, Vol. 6, No. 1 (ORNL/TM-11568N6\&N1), 1995."

"Avallable for purchase from National Technical Information Service, Springfield, VA 22161. 


\section{Microstructural Analysis of Radiation Effects}

\section{R. E. Stoller, P. J. Pariege, P. M. Rice, and M. K. Miller}

\subsection{Atom-Probe Field-lon Microscopy}

\section{Neutron Irradiated and Annealed Surveillance Materials}

Commercial materials were obtained from the Babcock \& Wilcox Owners Group that had been irradiated in their Master Integrated Surveillance Program and thermally aged for times up to $103,000 \mathrm{~h}^{1,2}$ These included weld, plate, and forging materials.

A detailed APFIM examination of the microstructure of a commercial A533B-type weld neutron irradiated $\left[3.5 \times 10^{19} \mathrm{n} / \mathrm{cm}^{2}(E>1 \mathrm{MeV})\right]$ at $283^{\circ} \mathrm{C}$ revealed a high number density $\left(\sim 3 \times 10^{17} \mathrm{~cm}^{-3}\right)$ of ultrafine $(2$ to $3 \mathrm{~nm}$ ) intragranular Cu-, P-, Ni-, Mn-, and Si-enriched clusters. The fact that these small clusters were not observed in the as-received and the long-term $(100,000 \mathrm{~h})$ thermally aged $\left(300^{\circ} \mathrm{C}\right)$ materials confirmed that their formation was either radiation-induced or radiation-enhanced. Atom-probe plane-by-plane-type analysis provided an accurate description of the solute distribution in these clusters. From the three-dimensional (3-D) reconstruction of these copper-enriched clusters, it was observed that copper atoms are mainly distributed in the core of the cluster, with a concentration of $\sim 8.5$ at. \%. $\mathrm{Mn}, \mathrm{Si}$, and $\mathrm{Ni}$ exhibited a wider spatial distribution around the center of the cluster. Since copper precipitation was observed in copper-containing steel aged at higher $\left(\sim 500^{\circ} \mathrm{C}\right)$ temperatures, the formation of copper-rich clusters in material irradiated at $\sim 300^{\circ} \mathrm{C}$ could be attributed to simple radiation-enhanced diffusion. Although other solutes (P, Ni, Mn, and $\mathrm{Si}$ ) are all detected in the same clusters, different processes of precipitation of these chemical species, such as radiation-enhanced for copper and radiation-induced for the other solutes, may be involved.

The matrix composition of these materials was also determined after neutron irradiation and two different thermal annealing treatments of either $168 \mathrm{~h}$ at $454^{\circ} \mathrm{C}$ or $29 \mathrm{~h}$ at $620^{\circ} \mathrm{C}$. The former annealing treatment is typical for an annealing treatment design to alleviate the effects of neutron irradiation, and the latter is a typical model stress-relief treatment. The changes in the copper content of the matrix during these stages are shown in Figure 7.1. The higher annealing temperature returns the copper content of the matrix to its original pre-service value. The low-temperature annealing treatment slightly reduces the copper content of the matrix and increases the size of the copper-enriched precipitates with a corresponding reduction in their number density. This observation may indicate that the copper content after neutron irradiation to a fluence of $3.5 \times 10^{19} \mathrm{n} / \mathrm{cm}^{2}(E>1 \mathrm{MeV}$ ) is still higher than the solubility limit, indicating the possibility of further copper precipitation. Such a conclusion would have serious implications for plant life extension to higher fluences, since it would indicate that the copper-driven component of embrittlement had not yet saturated. An alternate explanation is that the irradiation leads to a modified (higher) solubility limit at $290^{\circ} \mathrm{C}$.

\section{Thermally-Aged Fe-Cu-Ni Model Alloys}

An APFIM characterization on a ternary Fe-1.28 wt \% Cu-1.43 wt \% Ni model alloy has been performed. Two sets of isothermal heat treatments at 400 and $500^{\circ} \mathrm{C}$ were selected to follow the decomposition of the solid solution. The results obtained from the atom probe experiments on the materials thermally aged for short aging times showed the presence of nickel in the core of the copper particles. The low enrichment factor of nickel in these particles $(\sim 1.5)$ seems to indicate that copper precipitates in the body-centered cubic matrix independently from nickel. A similar low value of the nickel enrichment factor (1.5) was found in particles in a sample aged for $21 \mathrm{~h}$ at $400^{\circ} \mathrm{C}$, indicating that the presence of nickel in small precipitates is not strongly temperature dependent. In addition, analyses of the copper particles in over-aged samples $\left(100 \mathrm{~h}\right.$ at $\left.500^{\circ} \mathrm{C}\right)$ confirm a severe nickel depletion (0.2). These results suggested that the copper precipitates form and coarsen by a classical nucleation, growth, and coarsening process. The nickel and iron originally in the core of the clusters appeared to be rejected from the particles during growing and coarsening. 


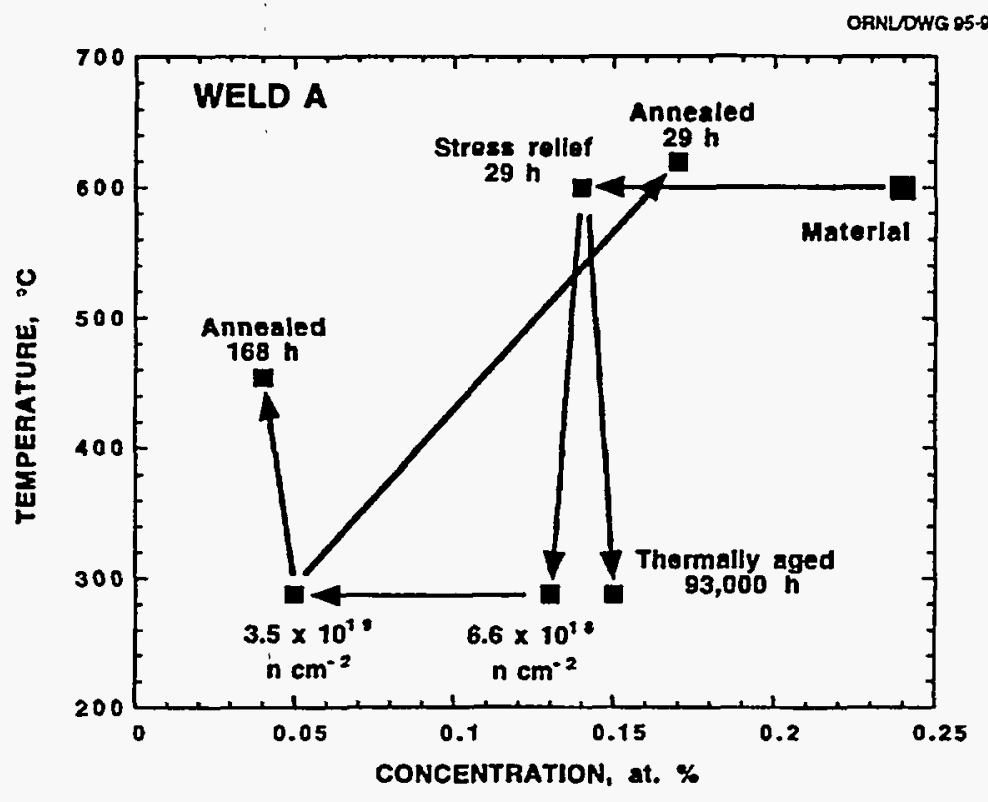

Figure 7.1. Evolution of matrix copper content in a commercial weld at various stages of heat treatment, irradiation, and following postirradiation annealing.

Comparison of these data with those observed in neutron-irradiated pressure vessel steels and $\mathrm{Fe}-0.28 \mathrm{wt} \% \mathrm{Cu}-0.7 \mathrm{wt} \% \mathrm{Ni}$ model steel, where nickel enrichment factor can reach values up to ten, indicated that thermally aged ternary FeCuNi alloy is not an appropriate model to enlighten the phase transformations in neutron-irradiated pressure vessel steels, and that the high nickel level in the clusters in the pressure vessel steels may be due to a neutron-induced precipitation process rather than a neutronenhanced precipitation process.

\subsection{Mechanical Properties and Microstructural Examinations}

A topical report (NUREG/CR-6332) was completed and submitted for publication that describes the irradiation and testing of Charpy specimens of two alloys, $A 212 B$ and $A 36$, that were irradiated in the cavity of the Trojan nuclear power plant prior to its shutdown. The specimens were irradiated at a temperature of about $65^{\circ} \mathrm{C}$ to a peak fluence of about $1 \times 10^{16} \mathrm{n} / \mathrm{cm}^{2}$. The higher target dose was not reached due to the early shutdown of the reactor and a lower-than-expected flux as the result of changes in the core configuration. Essentially no shift in the ductile-to-brittle transition temperature (DBTT) was observed in either alloy. A comparison of the A36 data with two other sets of unirradiated data highlighted the broad range of properties that can be obtained from a single plate of this alloy.

This task assumed responsibility for the disposition of two irradiation capsules that were originally built for the NRC by another contractor. The two capsules, designated FNR-11B and FNR-17A, were irradiated in the FNR at the $U$. of $M$. in an experiment investigating the effect of displacement rate. The capsules have been shipped to ORNL and disassembled. A plan for specimen testing and analysis of the dosimetry is being developed. Since irradiation of FNR-17A was terminated well short of its target fluence, the possibility of including some of the specimens in another irradiation vehicle is being investigated.

The mechanical testing of the Fe-Cu model alloys has led to an improved correlation of Vickers hardness and nanohardness changes in both irradiated and thermally aged alloys. Figure 7.2 demonstrates the 


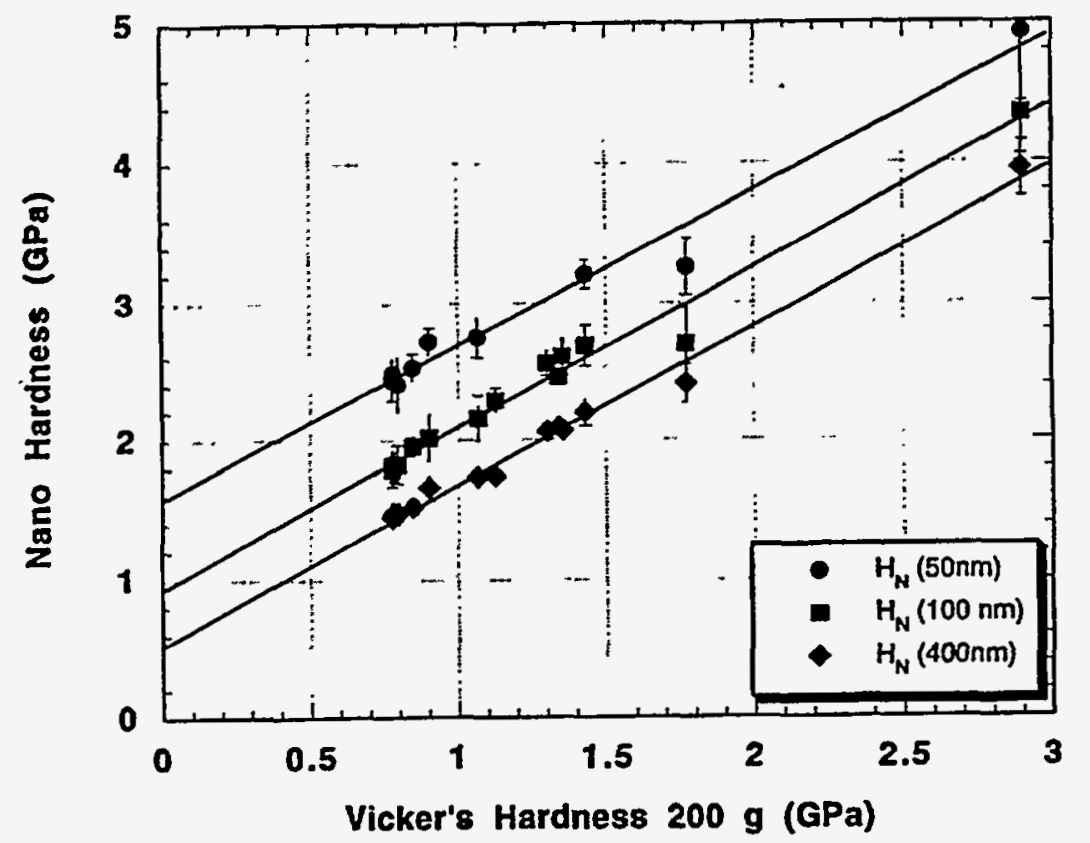

Figure 7.2. Comparison of hardness change measured in various ion-irradiated and aged steels by nanoindenter and 200-g Vickers; indentation depths for the nanohardness data $\left(H_{H}\right)$ are indicated in the legend.

correlation obtained between nanoindentation and $200-g$ Vickers measurements made on a range of commercial and model alloys. The three curves shown in Figure 7.2 indicate the linearity of the correlation for three different nanoindentation depths. Since the correlation between Vickers hardness changes and yield strength changes is well established, this new correlation will permit us to make reasonable estimates of radiation-induced yield strength changes from the nanohardness measurements made on ion-irradiated samples.

A final series of ion irradiations was completed to permit the examination of the hardening effect of microvoids. The complete set of nine model alloys was irradiated with $2.5 \mathrm{MeV}$ helium ions at $280^{\circ} \mathrm{C}$. The helium ion irradiated specimens will yield a larger volume for TEM examination than have the iron ion irradiated samples used previously. In addition, short aging treatments at temperatures in the range of 550 to $650^{\circ} \mathrm{C}$ are planned to cause the formation of small helium bubbles which can be investigated as a surrogate for the microvoids that are believed to form in neutron irradiated pressure vessel steels. In this way, the effect of both vacancy and interstitial-type defects can be examined, and the appropriate hardening superposition law can be determined.

\subsection{Modeling and Data Analysis}

Earlier predictions of the embrittlement model have indicated that the Charpy shift should be only weakly dependent on fast neutron flux or atomic displacement rate for the range of values encountered in RPV surveillance programs and low-to-intermediate flux test reactor irradiations. An initial confirmation of this prediction was obtained when comparing test reactor and surveillance program irradiations of the A533B plate HSST-02 correlation monitor. Data on the irradiation of this material in surveillance programs at fast fluxes from 2 to $15 \times 10^{10} \mathrm{n} / \mathrm{cm}^{2} / \mathrm{s}$ were compared with data obtained in test reactor irradiations at a flux of $\sim 3 \times 10^{12} \mathrm{n} / \mathrm{cm}^{2} / \mathrm{s}$. No effect of flux was observed for fluences up to $2 \times 10^{19} \mathrm{n} / \mathrm{cm}^{2}$. Similar results were 
observed for the single forging material evaluated. A broader range of materials will be examined to verify and extend these observations.

The embrittlement models developed under this task are based on reaction rate theory. While this theory has been broadly and successfully applied in radiation damage research, some shortcomings of the models have been exposed when they are applied at temperatures below 300 to $350^{\circ} \mathrm{C}$. These shortcomings have been largely compensated for by adjusting material parameters. Analysis of our molecular dynamics (MD) cascade simulations has suggested some improvements to the basic theory that should remove these shortcomings. For example, the MD results have revealed that small interstitial clusters are much more mobile than expected, and including the effects of these mobile clusters should improve the behavior of the models at the temperatures of interest to RPV steels.

Initial work with the reformulated embrittlement model and further analysis of the MD results indicated the need to further modify the model to reflect the possibility of easy glide and one-dimensional (1-D) diffusion of the small interstitial clusters, and to account for their trapping by other defects. If simple 3-D diffusion is assumed, the high mobility of the clusters would rapidly eliminate them as a significant point defect sink and hardening center. Since the sink strength for 1-D diffusion is much reduced from that for 3-D diffusion, ${ }^{3}$ and the MD results indicate that strong trapping is possible, more of the clusters may survive and contribute to mechanical property changes. Significant further model development is under way to properly account for these phenomena.

\section{References}

1. A. L. Lowe, Jr., "Thermal Aging Capsule Results from Oconee Nuclear Station-Unit 1," pp. 146-54 in Radiation Embrittlement and Surveillance of Nuclear Reactor Pressure Vessels, An Intemational Study, ASTM STP 819, L. E. Steele, Ed., American Society for Testing and Materials, Philadelphia, 1983.*

2. M. J. De Van, A. L. Lowe, Jr., and S. Wade, "Evaluation of Thermal Aged Plants, Forgings and Submerged Arc Weld Metals," pp. 268-82 in Effects of Radiation on Materials: 16th Intemational Symposium, ASTM STP 1175, A. S. Kumar, D. S. Gelles, R. K. Nanstad, and E. A. Little, Eds., American Society for Testing and Materials, Philadelphia, 1993.*

3. U. M. Gosele, "Reaction Kinetics and Diffusion in Condensed Matter," Prog. React. Kinet. 13, 63-161 (1984).*

*Available in public libraries. 


\title{
8. In-Service Irradiated and Aged Material Evaluations
}

\author{
F. M. Haggag, R. K. Nanstad, and D. J. Alexander
}

The objective of this task is to provide a direct assessment of actual material properties in irradiated components of nuclear reactors, including the effects of irradiation and aging. Four activities are currently in progress:

(1) establishing a machining capability for contaminated or activated materials by completing procurement and installation of a computer-based milling machine in a hot cell; (2) machining and testing specimens from cladding materials removed from the Gundremmingen reactor to establish their fracture properties; (3) preparing an interpretive report on the effects of neutron irradiation on cladding; and (4) continuing the evaluation of long-term aging of austenitic structural stainless steel weld metal by metallurgically examining and testing specimens aged at 288 and $343^{\circ} \mathrm{C}$ and reporting the results, as well as by continuing the aging of the stainless steel cladding toward a total time of $50,000 \mathrm{~h}$.

\subsection{In-Service Aging}

Type 308 stainless steel weldments were aged at $343^{\circ} \mathrm{C}$ for up to $50,000 \mathrm{~h}$. Tensile and CVN specimens were fabricated from the weld metal. Aging had little effect on the tensile properties but did result in embrittlement as shown by the impact testing. The degree of embrittlement increased with increasing ferrite content; the DBTT increased and the USE decreased. The embrittlement continues to increase with increasing aging time. A draft report summarizing the results of these tests is being written.

\subsection{Remotely Operated Machining Center}

Modification of the computer numerically controlled (CNC) machining center (model VMC-100) is in progress. Several items have been completed, including drawings, new cables and table, machine enclosure, fittings, and a floor tub for installation inside the hot cell. Also, the automated ball indentation machine was moved from cell 6 to cell 2 to provide a place for the CNC machine. Hot cell decontamination and new crane installation are in progress. Furthermore, a new saw was purchased for slicing specimens into suitable sizes for machining on the CNC machine.

\subsection{Thermal Aging of Stainless Steel Weld Overlay Cladding}

Tensile, CVN, and fracture toughness testing of three-wire stainless steel cladding, thermally aged for $20,000 \mathrm{~h}$ at 288 and $343^{\circ} \mathrm{C}$, was completed. The test results show that the effects of thermal aging at both temperatures were very small and similar to those reported earlier for $1605-\mathrm{h}$ aging at $288^{\circ} \mathrm{C}$. Hence, aging of additional three-wire cladding at $288^{\circ} \mathrm{C}$ for $50,000 \mathrm{~h}$ and greater (completion expected in July 1996) is continuing to better quantify the effects of long-term thermal aging.

A NUREG report, Effects of Thermal Aging and Neutron Irradiation on the Mechanical Properties of Three-Wire Stainless Steel Weld Overlay Cladding [NUREG/CR-6363 (ORNL/TM-13047)], by F. M. Haggag and R. K. Nanstad, was completed and is now being prepared for publication. 


\title{
9. JPDR Pressure-Vessel Steel Examination
}

\author{
W. R. Corwin and M. A. Sokolov
}

There is a need to validate the results of irradiation effects research by the examination of material taken directly from the wall of a pressure vessel which has been irradiated during normal service. This task has been included within the HSSI Program to provide just such an evaluation on material from the wall of the pressure vessel from the JPDR.

The JPDR was a small boiling-water reactor that began operation in 1963. It operated until 1976, accumulating $\sim 17,000 \mathrm{~h}$ of operation, of which a little over $14,000 \mathrm{~h}$ were with the original $45-\mathrm{MWTh}$ core, and the remaining fraction, late in life, with an upgraded 90-MWTh core. The pressure vessel of the JPDR, fabricated from A 302, grade $B$, modified steel with an internal weld overlay cladding of 304 stainless steel, is approximately $2 \mathrm{~m}$ ID and $73 \mathrm{~mm}$ thick. It was fabricated from two shell halves joined by longitudinal seam welds located $180^{\circ}$ from each other. The rolling direction of the shell plates is parallel to the axis of the vessel. It operated at $273^{\circ} \mathrm{C}$ and reached a maximum fluence of about $2.3 \times 10^{18} \mathrm{n} / \mathrm{cm}^{2}(>1 \mathrm{MeV})$. The impurity contents in the base metal are 0.10 to $0.11 \% \mathrm{Cu}$ and 0.010 to $0.017 \% \mathrm{P}$ with a nickel content of 0.63 to $0.65 \%$. Impurity contents of the weld metal are 0.11 to $0.14 \% \mathrm{Cu}$ and 0.025 to $0.039 \% \mathrm{P}$ with a nickel content of $0.59 \%$.

The current status of the JPDR pressure vessel is that it has been cut into pieces, roughly $800 \times 800 \mathrm{~mm} \times$ the original local wall thickness. Full-thickness trepans have been cut from one of the sections originally located at the core beltline and from one of the sections near the upper flange, well away from the beltline. Eight beltline trepans were removed containing the longitudinal fabrication weld as were eight beltline trepans located completely within the base metal. Nine remotely located trepans were taken containing the longitudinal fabrication weld as were 14 containing only base metal. Japan Atomic Energy Research Institute (JAERI) has shipped the irradiated material from the wall of the JPDR that will be examined at ORNL, where it was subsequently received, and moved into the hot cells where it is to be machined and examined. The material received at ORNL consists of 16 full-thickness trepans, each approximately $87 \mathrm{~mm}$ in diameter. The trepans contain four types of material: weld metal and base metal, each in both the irradiated condition (from the beltine) and in nominally, thermally aged-only condition (from the upper flange). ORNL received four trepans of each material. JAERI has placed all the remaining vessel material in a hot warehouse on-site for long-term storage and currently has no plans to do anything else with it.

The objectives of the JAERI JPDR pressure vessel investigations are to obtain materials property information on the pressure-vessel steel actually exposed to in-service irradiation conditions and to help validate the methodology for aging evaluation and life prediction of RPVs. The Japanese research associated with the evaluation of irradiation effects is composed of three parts: examination of material from the JPDR vessel in conjunction with a re-evaluation of its exposure conditions, new test reactor irradiations of archival and similar materials, and re-evaluation of data from irradiation surveillance and related programs. The focus of the research to be performed by ORNL on the JPDR material is the determination of irradiation-induced damage through the thickness of the vessel in the beltline region and its comparison with the properties and microstructural evaluations of the same material following short, high-rate irradiations or with thermal damage only. This will be done by fabricating fracture and microstructural specimens from the trepans taken from the beltline and from the region remote from the beltline. Parallel determinations of exposure will be made by dosimetry measurements taken on the vessel material itself and by supporting neutron transport calculations.

During this reporting period, the ORNL baseline testing for the cross comparison of the effects of the different tups used in U.S. and Japanese Charpy impact machines was performed. The purpose of the testing was to compare Charpy impact data on the same materials tested at two laboratories according to their own national standards which are currently in force. This will provide a basis for evaluating any differences that might later arise from testing of the JPDR materials jointly by ORNL and JAERI.

All tests at ORNL have been performed in compliance with ASTM "Standard Test Methods for Notched Bar Impact Testing of Metallic Materials" (E 23-93a) and "Standard Practice for Effects of High-Energy Neutron Radiation on the Mechanical Properties of Metallic Materials" (E 184-79). A 326-J (240-ft-lb)-capacity pendulum-type impact machine, Baldwin Model SI1C, was used. The ASTM 8-mm-wide striker is instrumented with strain gages to provide 
a load-time record, but all energy values reported herein were obtained from the dial energy. The machine is equipped with semiautomated specimen thermal conditioning and transfer systems. The transfer system places the specimen in the thermal conditioning system which heats the specimen by contact with graphite electrodes, cools the specimens with cold nitrogen gas, and includes a calibrated contact TC for temperature measurement. The transfer system allows for transfer of the specimen to the anvils for testing in less than $\mathbf{5} \mathbf{s}$ following removal from the conditioning chamber. The percent shear fracture was visually measured according to ASTM E 23 guidance, and the lateral expansion was measured with a device similar to that described in ASTME 23.

Two materials were used in this study. One of those was A 533 grade $B$ class 1 pressure-vessel plate, designated HSST plate 13A. Broken halves of previously tested 2T compact specimens were used in the present study.

Specimens are L-T oriented. Ten specimens have been tested at each test temperature, namely $-30,0$, and $60^{\circ} \mathrm{C}$. These temperatures were selected to represent lower, middle, and upper regions of the DBTT curve, respectively. Table 9.1 summarizes average and one standard deviation (s) values of absorbed energy, lateral expansion, and shear fracture at each test temperature.

Table 9.1. Average and one standard deviation values of absorbed energy, lateral expansion, and shear fracture of HSST plate 13A tested at ORNL

\begin{tabular}{||l|l|l|l||}
\hline \hline $\begin{array}{c}\text { Test temperature, } \\
{ }^{\circ} \mathrm{C}\end{array}$ & $\begin{array}{c}\text { Absorbed energy, } \\
\mathrm{J}\end{array}$ & $\begin{array}{c}\text { Lateral expansion, } \\
\mathrm{mm}\end{array}$ & \multicolumn{1}{c|}{$\begin{array}{c}\text { Shear, } \\
\%\end{array}$} \\
\hline-30 & $50.9 \pm 16.2$ & $0.76 \pm 0.20$ & $11 \pm 6$ \\
\hline 0 & $92.9 \pm 12.7$ & $1.37 \pm 0.16$ & $48 \pm 10$ \\
\hline 60 & $143.0 \pm 8.3$ & $1.94 \pm 0.06$ & $99 \pm 2$ \\
\hline
\end{tabular}

The second material was a block of JPDR Poison Tank material supplied by JAERI. Specimens were cut from the $1 / 4$ thickness level from the external surface of plate and were T-L oriented. Ten specimens have been tested at each test temperature, namely 0,40 , and $100^{\circ} \mathrm{C}$. Table 9.2 summarizes average and one standard deviation values of the measured properties.

Table 9.2. Average and one standard deviation values of absorbed energy, lateral expansion, and shear fracture of JPDR Poison Tank material tested at ORNL

\begin{tabular}{||c|c|l|c|}
\hline \hline $\begin{array}{c}\text { Test temperature, } \\
{ }^{\circ} \mathrm{C}\end{array}$ & \multicolumn{1}{|c|}{$\begin{array}{c}\text { Absorbed energy, } \\
\mathrm{J}\end{array}$} & \multicolumn{1}{|c|}{$\begin{array}{c}\text { Lateral expansion, } \\
\mathrm{mm}\end{array}$} & \multicolumn{1}{c|}{$\begin{array}{c}\text { Shear, } \\
\%\end{array}$} \\
\hline 0 & $35.4 \pm 4.2$ & $0.71 \pm 0.07$ & $11 \pm 2$ \\
\hline 40 & $72.1 \pm 5.2$ & $1.29 \pm 0.07$ & $68 \pm 8$ \\
\hline 100 & $101.0 \pm 6.4$ & $1.68 \pm 0.08$ & $100 \pm 0$ \\
\hline
\end{tabular}

Results from this testing will be compared with testing performed at JAERI on identical materials at identical temperatures to assess the effects of the differences in tup geometry for impact testing performed on materials with varying levels of USE and in different parts of the transition region. 


\section{Fracture Toughness Curve Shift Method}

\section{R. K. Nanstad, M. A. Sokolov, and D. E. McCabe}

The purpose of this task is to examine the technical basis for the currently accepted methods for shifting fracture toughness curves to account for irradiation damage, and to work through national codes and standards bodies to revise those methods, if a change is warranted. Specific activities under this task include: (1) collection and statistical analysis of pertinent fracture toughness data to assess the shift and potential change in shape of the fracture toughness curves due to neutron irradiation, thermal aging, or both; (2) evaluation of methods for indexing fracture toughness curves to values that can be deduced from material surveillance programs required under the Code of Federal Regulations (10CFR50), Appendix H; (3) participation in the pertinent ASME Boiler and Pressure Vessel Code, Section XI, ASTM E-8, and ASTM E-10 committees to facilitate obtaining data and disseminating the results of the research; (4) interaction with other researchers in the national and international technical community addressing similar problems; and (5) frequent interaction, telephone conversations, and detailed technical meetings with the NRC staff to ensure that the results of the research and proposed changes to the accepted methods for shifting the fracture toughness curves reflect staff assessments of the regulatory issues.

In the previous semiannual report, ${ }^{1}$ preliminary analysis of all relevant HSSI Program data was presented and discussed. Using Weibull statistics, it was shown that the maximum likelihood approach gave good estimations of the fracture toughness reference temperature, $T_{0}$ (the temperature at $100 \mathrm{MPa} / \mathrm{m}$ ), determined by rank method and could be used for analyzing data sets where application of the rank method did not prove feasible. It was shown by a linear least-squares fit to the data set that, on average, the fracture toughness shifts generally exceeded the Charpy $41-\mathrm{J}$ shifts by about $15 \%$. This result is dominated by the data with shifts greater than about $30^{\circ} \mathrm{C}$. Results obtained from the adjustment procedures mentioned above are in a published letter report. ${ }^{2}$

During this reporting period, other data from the published literature were acquired, and a preliminary analysis was performed. In this preliminary analysis, the raw data were not analyzed by ORNL; rather, the irradiation-induced shifts reported by the authors were used. In all cases, the fracture toughness and CVN temperature shifts were determined at $100 \mathrm{MPa} / \mathrm{m}$ and $41 \mathrm{~J}$, respectively. Figures 10.1 through 10.3 show graphical comparisons of all the data in this preliminary analysis for plates, ${ }^{36}$ forgings, ${ }^{3,6,7}$ and welds, ${ }^{3-5,7-9}$ respectively. As shown by linear leastsquares fit to the data sets, on average, the fracture toughness shifts generally exceeded the Charpy $41 J$ shifts by about 20,50 , and $8 \%$ for plates, forgings, and welds, respectively. The figures also reveal a high amount of scatter in the results. The overall scatter is also evident in Figure 10.4, which is a plot of all the data with a linear leastsquares fit. In this case, on average, the fracture toughness shifts exceed the CVN shifts by about $14 \%$. Future efforts on this task consist of continuing development of the database, and analysis of the raw data, including tensile data, with a view toward development of a fracture toughness/CVN/tensile shift comparison that minimizes the scatter in the data.

\section{References}

1. R. K. Nanstad, M. A. Sokolov, and D. E. McCabe, Martin Marietta Energy Systems, Inc., Oak Ridge Natl. Lab., "Fracture Toughness Curve Shift Method," pp. 45-47 in Heavy-Section Steel Irradiation Program, Progress Report for October 1994-March 1995, USNRC Report NUREG/CR-5591, Vol. 6, No. 1 (ORNLTM-11568N6\&N1), 1995.*

2. M. A. Sokolov and D. E. McCabe, Martin Marietta Energy Systems, Inc., Oak Ridge Natl. Lab., Comparison of Irradiation-Induced Shifts of $K_{\mathcal{L}}$ and Charpy Curves: Analysis of Heavy-Section Steel Irradiation Program Data, ORNLNRC/LTR-95/4 (June 1995).*

3. A. L. Hiser, Materials Engineering Associates, Inc., Lanham, Md., Correlation of Irradiation-Induced Transition

Temperature Increases from $C_{v}$ and $K_{k} / K_{k}$ Data, USNRC Report NUREG/CR-5494 (MEA-2377), March 1990.*

4. R. J. McElroy et al., AEA Technology, Harwell, United Kingdom, Optimisation of Reactor Pressure Vessel Surveillance Programmes and their Analysis, AEA-RS-2426, December 1993.† 


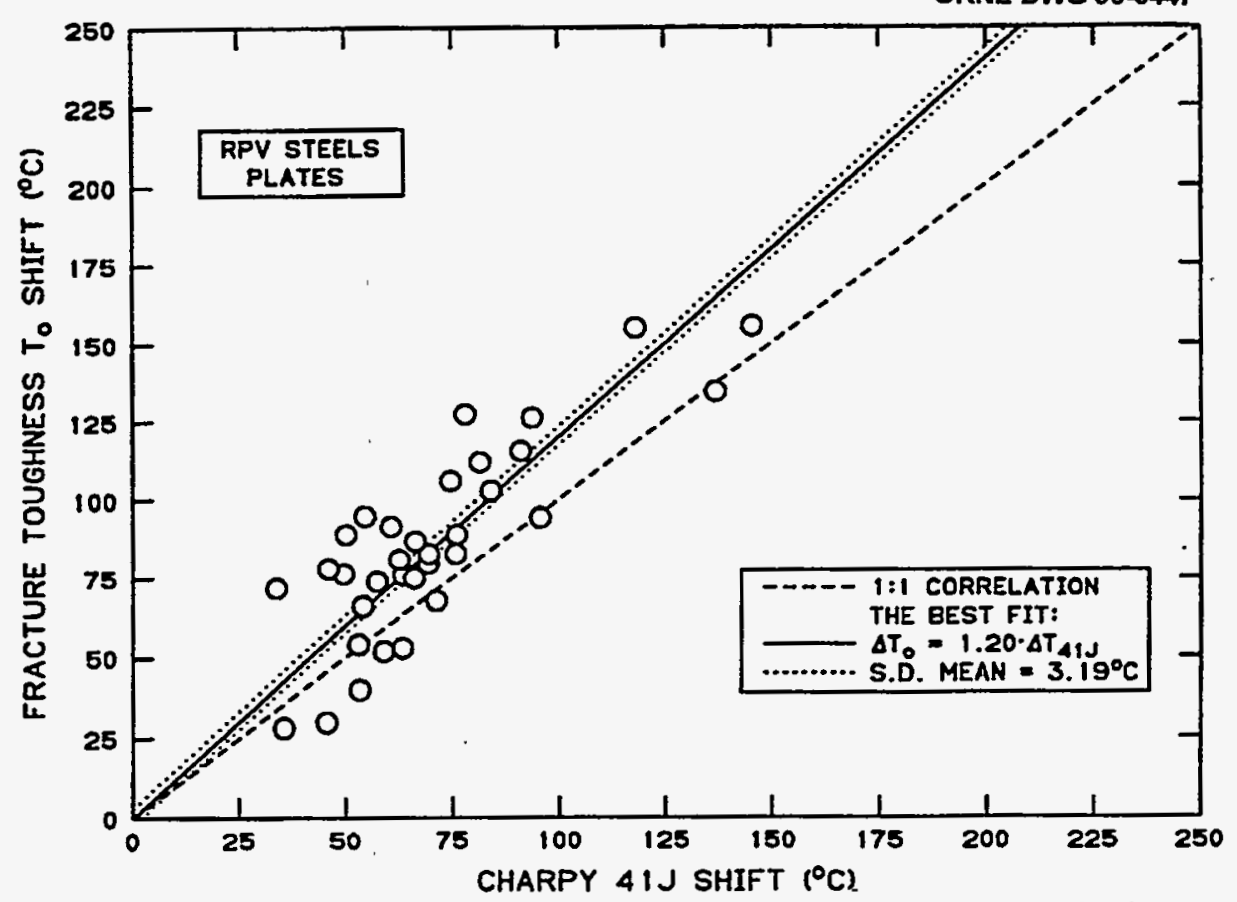

Figure 10.1. Comparison of irradiation-induced temperature shifts for reactor pressure vessel plate steels determined from fracture toughness and Charpy V-notch impact tests at 100 $\mathrm{MPa} / \mathrm{m}$ and $41 \mathrm{~J}$, respectively.

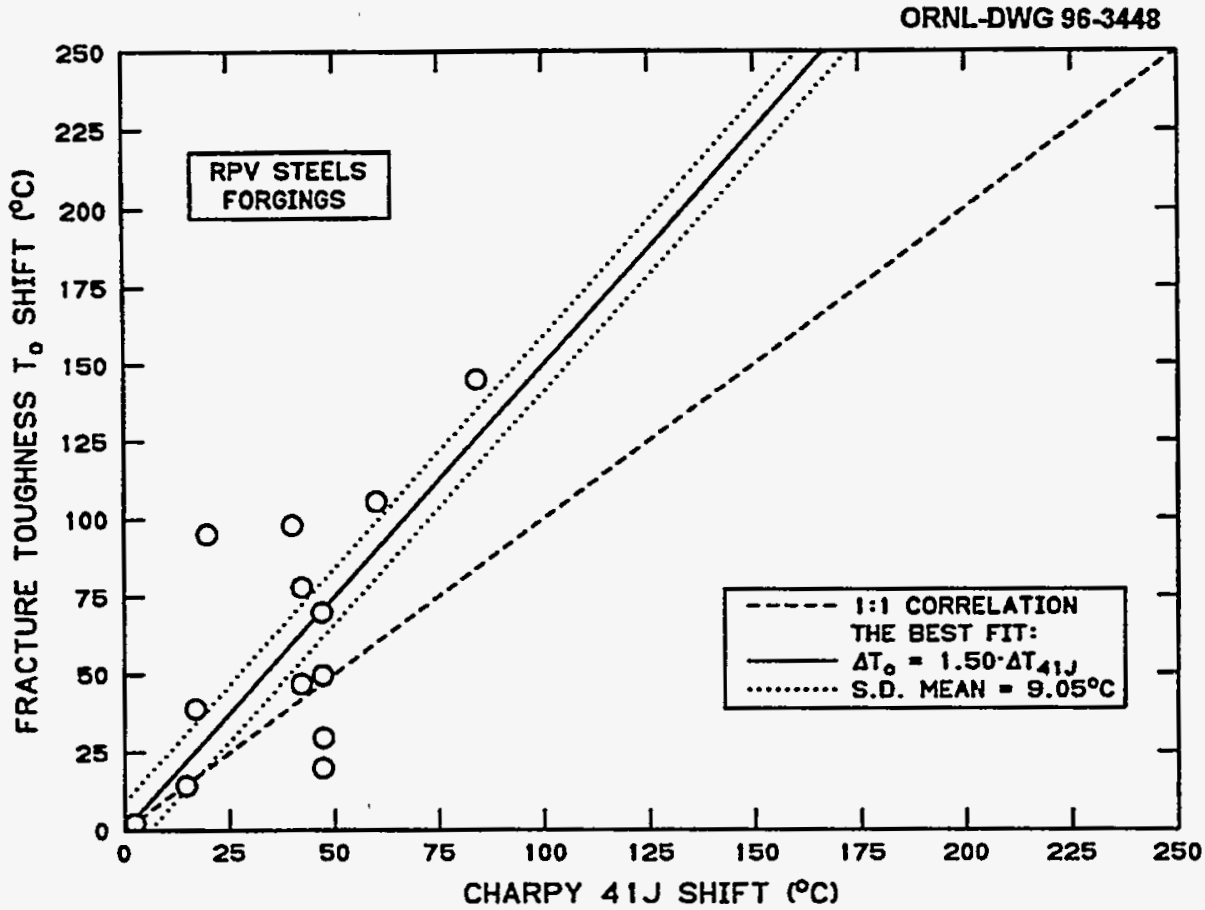

Figure 10.2. Comparison of irradiation-induced temperature shifts for reactor pressure vessel forging steels determined from fracture toughness and Charpy V-notch impact tests at $100 \mathrm{MPa} \sqrt{\mathrm{m}}$ and $41 \mathrm{~J}$, respectively. 


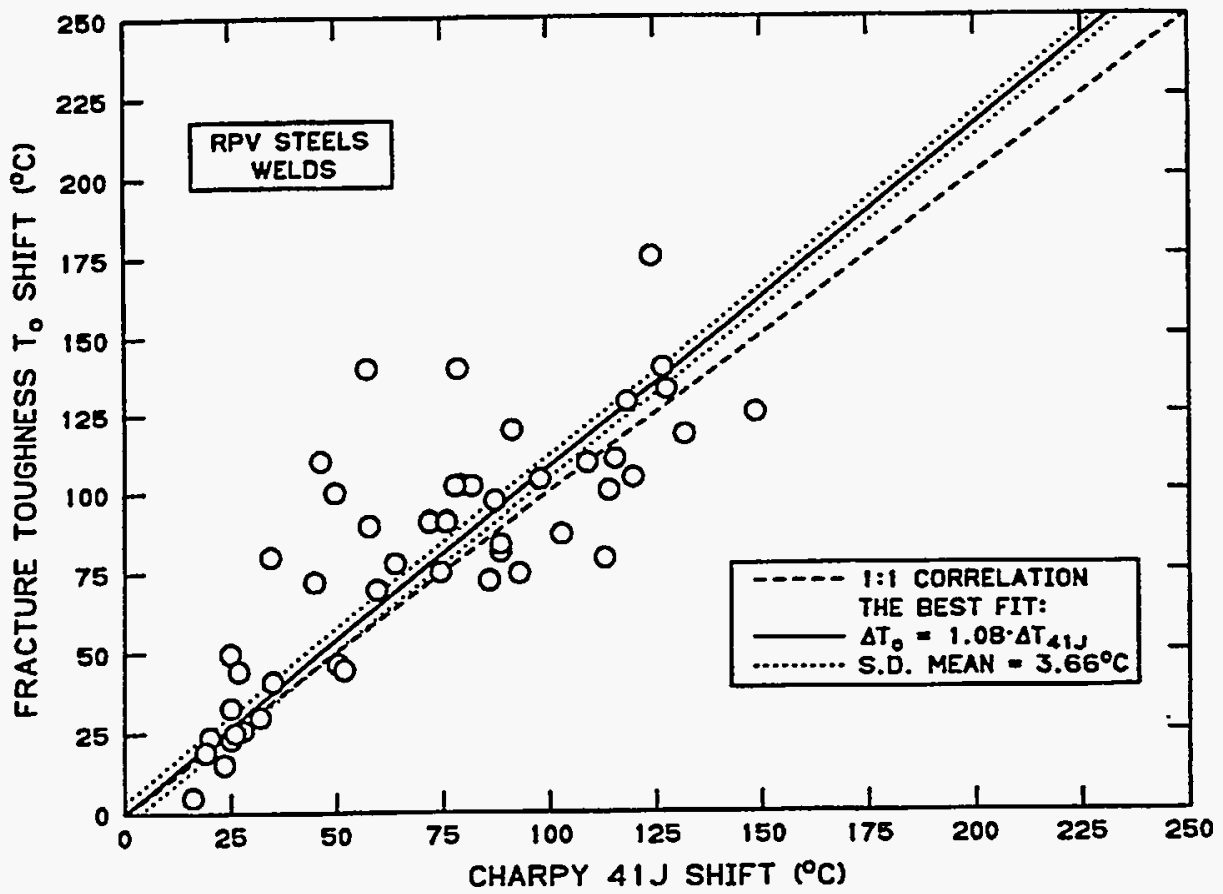

Figure 10.3. Comparison of irradiation-induced temperature shifts for reactor pressure vessel welds determined from fracture toughness and Charpy V-notch impact tests at $100 \mathrm{MPa} \sqrt{\mathrm{m}}$ and $41 \mathrm{~J}$, respectively.

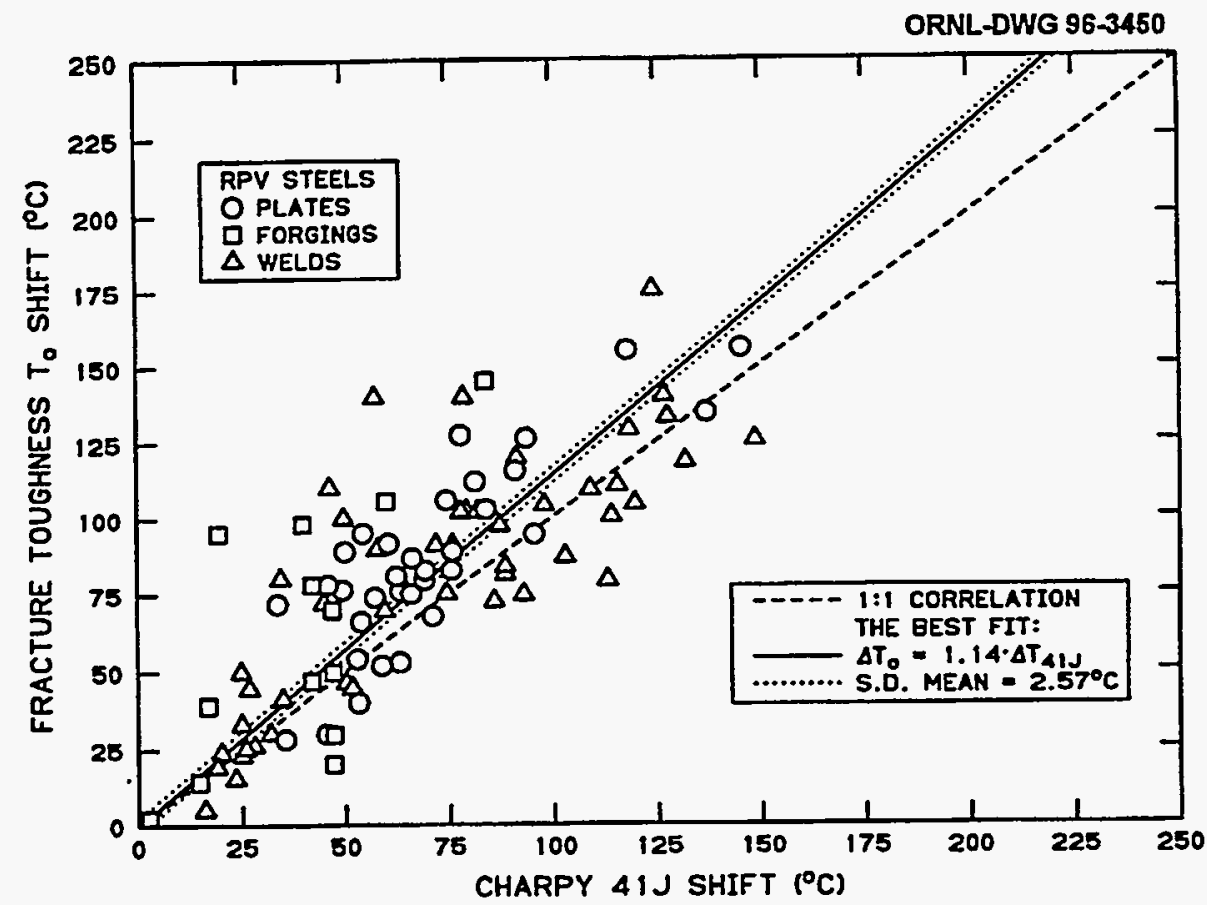

Figure 10.4. Comparison of irradiation-induced temperature shifts for reactor pressure vessel steels (plates, forgings, and welds) determined from fracture toughness and Charpy V-notch impact tests at $100 \mathrm{MPa} \sqrt{\mathrm{m}}$ and $41 \mathrm{~J}$, respectively. 
5. J. J. McGowan, R. K. Nanstad, and K. R. Thoms, Martin Marietta Energy Systems, Inc., Oak Ridge Natl. Lab., Characterization of Irradiated Current-Practice Welds and A 533 Grade B Class 1 Plate for Nuclear Pressure Vessel Service, USNRC Report NUREG/CR-4880, Vol. 1 (ORNL-6484N1), July 1988.*

6. K. Wallin et al., "The Effect of Loading Rate Upon Irradiation Embrittlement Measured by Fracture Mechanical Properties," pp. 156-71 in Effects of Radiation on Materials: 16th Intermational Symposium, ASTM 1175, American Society for Testing and Materials, Philadelphia, 1993. $†$

7. M. Brumovsky, P. Novosad, and J. Zdarek, "Surveillance Programme for WWER-440/Type 213 Reactor Pressure Vessels - Standard Programme, Re-evaluation of Results, Supplementary Programme," in Effects of Radiation on Materials: 17th Volume, ASTM STP 1270, American Society for Testing and Materials, Philadelphia, 1996.

8. R. K. Nanstad et al., Martin Marietta Energy Systems, Inc., Oak Ridge Natl. Lab., Irradiation Effects on Fracture Toughness of Two High-Copper Submerged-Arc Welds, HSSI Series 5, USNRC Report NUREG/CR-5913, Vol. 1 (ORNLTM-12156N1), October 1992.",

9. D. E. McCabe et al., Martin Marietta Energy Systems, Inc., Oak Ridge Natl. Lab., Effects of Irradiation to 0.5 and $1.0 \times 10^{19}$ neutrons $/ \mathrm{cm}^{2}(>1 \mathrm{MeV}$ ) on the Midland Reactor Low Upper-Shelf Welds: Capsules 10.01, 10.02, and 10.05 in the Heavy-Section Steel Irradiation Program Tenth Irradiation Series, USNRC Report

ORNLNRC/LTR-95/18, August 1995.*

"Available for purchase from National Technical Information Service, Springfield, VA 22161.

†Available in public technical libraries. 


\title{
11. Special Technical Assistance
}

\author{
S. K. Iskander, D. J. Alexander, R. K. Nanstad, and M. A. Sokolov
}

The purpose of this task is to perform various special analytical and experimental investigations to support the NRC in resolving regulatory research issues related to irradiation effects on materials. This task currently addresses two major areas: (1) providing technical expertise and assistance in the review of national codes and standards and

(2) experimental evaluations of test specimens and practices and material properties.

\subsection{Plan to Survey Variability in Chemical, Mechanical, and Toughness Properties of the Pressure Vessel Research Users Facility Reactor Vessel (S. K. Iskander, D. E. McCabe, E. T. Manneschmidt, and J. J. Henry, Jr.)}

Subtask 11.8 directs the HSSI Program to perform "a survey of the variability in chemical composition and fracture properties on the welds of the reactor vessel in the user facility at ORNL....". Furthermore, it requires that this survey include the determination of the variations of properties in the depth and circumferential directions within the beltline welds of the vessel. The mechanical properties will include CVN impact, DWT, and small specimen fracture toughness, up to 1TC (T).

Besides this task, the HSST Program and Battelle Pacific Northwest Laboratories (PNL) also have needs for material containing welds from this vessel. PNL had previously performed nondestructive examination (NDE) of the vessel welds and would like material to verify the NDE indications that were recorded.

This task has been divided into the following subtasks:

1. Formulate test matrix and specimen complement and determine the number of linear feet of weld required for the HSSI task.

2. Coordinate PNL, HSST, and HSSI requirements for material.

3. Obtain estimates on time and costs for removing the material from the Pressure Vessel Research Users Facility (PVRUF) vessel.

4. Issue a purchase requisition to the vessel manufacturer, ABB-CE, to compile information on the circumferential weld (weld metal shape, chemical, and mechanical properties of weld and plate material). There are several boxes of documentation for the vessel, and the vessel manufacturer has the experience to extract this information more efficiently than ORNL.

\section{Test Matrix, Specimen Complement, and Number of Linear Feet of Weld Required}

The preliminary test plan given below has benefited from the sampling plan performed in a similar survey for the Tenth Irradiation Series. ${ }^{1,2}$ Of interest are the three axial welds and the circumferential beltline weld shown hatched on a developed view of the vessel given in Figure 11.1. They were fabricated using the same heat of weld wire and lot of flux and have the ABB-CE designation E3.07. The internal diameter of the vessel is $4390 \mathrm{~mm}$ (173 in.), and it was manufactured from 245 -mm-thick ( $95 / 8$-in.) steel plate purchased according to SA-533 grade B class 1 specifications. Four locations equally spaced in the circumferential direction will be sampled to determine 


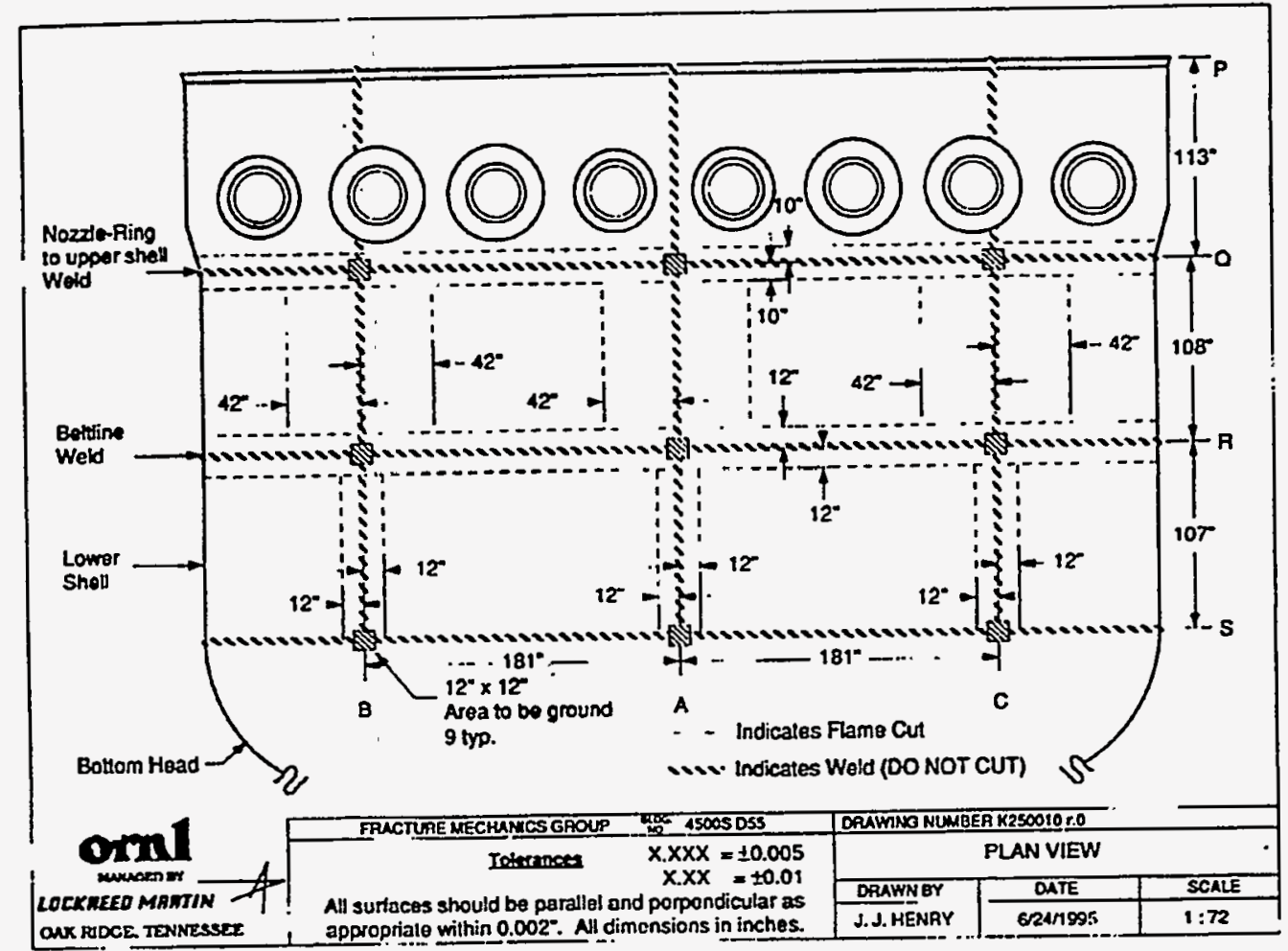

Figure 11.1. Developed view of the Pressure Vessel Research Users Facility vessel located near Building K-702 at the K-25 site.

the circumferential variability. For purposes of reference, the cladding/base metal interface will be designated as the (0)t depth. The weld root is assumed* to be at $\sim 1 / 3(t)$, and the locations on either side of the root and toward the inner and outer surfaces will be designated $1 / 3(t) l$ and $1 / 3(t) O$, respectively. To minimize the linear length of weld needed, as well as obtain twice as much data from a single location in the vessel wall, two adjacent specimen layers will be machined at each nominal depth.

The detailed variations in chemical, mechanical, and toughness properties through the 245-mm-thick ( 9 5/8-in.) base metal wall will be determined using CVN and tensile specimens. These two specimen types will be machined from the following seven depths in the wall: $1 / 8(t), 1 / 4(t), 1 / 3(t) l, 1 / 3(t) O, 1 / 2(t), 3 / 4(t)$, and $7 / 8(t)$. The $1 / 8(t)$ and $7 / 8(t)$ locations sample some near-inside and near-outside surface material. A small number of PCVN specimens will also be tested to obtain data on the usefulness of PCVN specimens. The variation in chemical composition will be obtained using the weld metal part of broken CVN specimen halves.

The crack-initiation toughness, $K_{\mathrm{Jc}}$, and DWT-NDT will be determined at the three depth locations already characterized by CVN and tensile testing, namely the $1 / 4(t), 1 / 2(t)$, and $3 / 4(t)$, using $1 T C(T)$ and DWT specimens. The variation of $K_{\mathrm{Je}}$ and NDT at other depths could be inferred from the variation in CVN and tensile results.

The specimen complements in terms of the number and size of precracked CVN, tensile, 1TC (T), and NDT specimens are given in Table 11.1 for each of the four azimuthal locations. A relatively large number of CVN specimens will be tested at each depth for statistical purposes, since the 85 unirradiated CVN specimens tested for the Fifth Series resulted in a spread of approximately $50^{\circ} \mathrm{C}$ at the $41-\mathrm{J}$ level. A valuable insight into the statistical

*In a telephone conversation with R. T. Johnson of ABB-CE, he said it is most likely a double-J weld, with the "land" at about one-third of the thickness. 
Table 11.1. Specimen complement in terms of the number and size of precracked Charpy, tensile, 1TC (T), and drop-weight specimens for each of the four azimuthal locations

\begin{tabular}{|c|c|c|c|}
\hline Specimen type & $\begin{array}{l}\text { Number of } \\
\text { specimens } \\
\text { per depth }\end{array}$ & $\begin{array}{l}\text { Number of } \\
\text { depths } \\
\text { sampled }\end{array}$ & Depths sampled" \\
\hline Charpy V-notch & 40 & 7 & $\begin{array}{l}1 / 8(t), 1 / 4(t), 1 / 3(t) \mid, 1 / 3(t) 0,1 / 2(t), \\
3 / 4(t), 7 / 8(t)\end{array}$ \\
\hline Tensile & 10 & 7 & $\begin{array}{l}1 / 8(t), 1 / 4(t), 1 / 3(t) \mid, 1 / 3(t) 0,1 / 2(t), \\
3 / 4(t), 7 / 8(t)\end{array}$ \\
\hline $\begin{array}{l}\text { Precracked Charpy } \\
\text { V-notch }\end{array}$ & 12 & 3 & $1 / 4(t), 1 / 2(t), 3 / 4(t)$ \\
\hline $1 T C(T)$ & 20 & 3 & $1 / 4(t), 1 / 2(t), 3 / 4(t)$ \\
\hline Drop-weight & 8 & 3 & $1 / 4(t), 1 / 2(t), 3 / 4(t)$ \\
\hline
\end{tabular}

variation of Charpy impact energy has recently been obtained by Nanstad* and is shown in Figure 11.2. The variations in the $41-\mathrm{J}$ transition temperature and the USE are -22 to $14^{\circ} \mathrm{C}$ and 78 to $108 \mathrm{~J}$ (58 to $80 \mathrm{ft}-\mathrm{Ib}$ ), respectively, and were obtained from 26 separate sets of Charpy curves for different depths and circumferential locations.

\section{Removal Plan for the Welds}

The overall plan at this time is to obtain as much as possible of the "single-type" weld designated E3.07. The length of the beltline weld is $\sim 45 \mathrm{ft}$. The two axial welds, one from the nozzle ring to the beltline and the second from the beltline to the bottom head weld seam, are each $9 \mathrm{ft}$ long, making the total length of the E3.07 weld $100 \mathrm{ft}$. A notable feature of each axial weld is that it is aligned and not the staggered-brickwork type. Thus, the junction of the axial and circumferential welds is in the shape of a "plus" sign. The weld material at these junctions is thus different from that at some distance away from these junctions. Allowing about $1 \mathrm{ft}$ ( 3 in. for each of the arms of the plus) for each of nine junctions leaves $\sim 90 \mathrm{ft}$ of weld.

The preliminary plan for the removal of the E3.07 weld is to flame cut all three circumferential welds. It should be noted that the nozzle ring to upper-shell weld is not an E3.07 weld; it would be flame cut with one flame-cut pass just below the nozzle-ring and another cut about $1 \mathrm{ft}$ below the weld centerline. About one-half of this weld is needed by PNL. A second ring about $2 \mathrm{ft}$ wide and centered on the beltine weld also would be removed. The third cut would part the bottom head from the shell courses. Besides the nozzle course and beltline welds, this would leave two shell courses, each containing three axial welds of interest. The net length of top-shell axial welds is each $\sim 7 \mathrm{ft}$ long, and those from the bottom-shell course are each $8 \mathrm{ft}$ long. Any three axial welds would be sufficient for the HSST programmatic needs mentioned below.

\section{Other Programmatic Requirements of Material}

The HSST Program has expressed an interest in about $18 \mathrm{ft}$ of an axial weld with $31 / 2 \mathrm{ft}$ of base metal on either side. As mentioned above, PNL has expressed an interest in one-half of the upper circumferential weld, as well as a major portion of the beltline weld. The HSSI Program needs $20 \mathrm{ft}$ of beltline weld in four 5 - $\mathrm{ft}$ sections equally

\footnotetext{
${ }^{\star}$ R. K. Nanstad, Oak Ridge Natl. Lab., personal communication to S. K. Iskander, Oak Ridge Natl. Lab., October 11, 1995.
} 


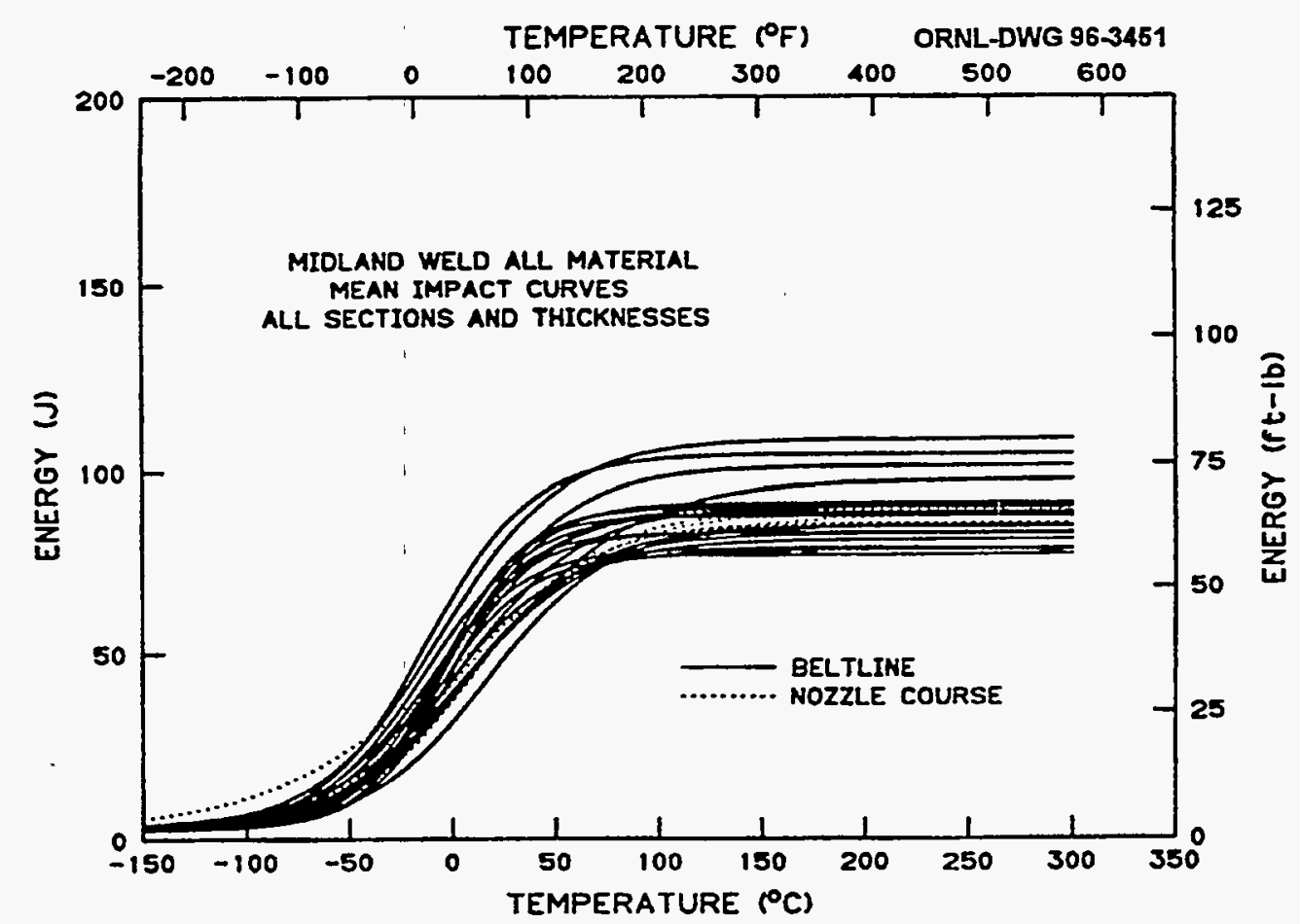

Figure 11.2. Variation of Charpy impact upper-shelf energy of 26 separate data sets from the Midland WF-70 material.

spaced around the circumference. There is an apparent overlap in the requirements of PNL and HSSI requirements. However, since the mission of PNL is to destructively examine the location of the indications they have, and the mission of the HSSI task is to machine specimens from the same material, it is obvious thato there is room for much mutually beneficial interaction.

Historically, once a material has been extensively characterized, extreme interest naturally develops, both within the NRC programs and internationally, to acquire this material to perform fracture mechanics research. Such an interest has already occurred with material used in HSST plates 02, 03, and 13, and in HSSI welds $72 W$ and $73 \mathrm{~W}$. it is important, therefore, to obtain and conserve as much as possible of weld E3.07.

Possible needs for this weld would be to survey the variations in chemistry and mechanical properties in weld beads that are closer to the fusion line as well as in the HAZ. Much of the previous research in the HSSI Fifth and Sixth Irradiation Series has purposely tested material from the central region of a very carefully fabricated narrow weld. The edge preparation was straight, and by the fabrication technique, the weld width was kept uniform throughout the depth at about $11 / 4$ in. wide, so that the entire weld thickness, except for the top $1 / 2$ in., was uniform. There were approximately three beads, and it was the central bead that was tested. There is a need to ensure that the properties elsewhere in the weld and HAZ are not inferior to those of the central portion. Another region of interest would be at the intersection of the axial and circumferential welds.

\section{General Considerations}

The PVRUF vessel is located in an area undergoing demolition of relatively large buildings, and for obvious security considerations, the area cannot be accessed by contractors other than those involved in the demolition activities. These activities are scheduled to continue, according to R. S. Seigler, Demolition Project Manager, until September 1996, and it is apparently the contractor's prerogative not to allow anyone into the demolition area. If the adjacent building will not be demolished, then there is significant financial incentive for the present contractor to be out of the area by the end of December 1995. However, if the adjacent building is demolished, as it most likely will be, then the area may not be accessible until May 1996. 
The material removal from the PVRUF vessel could wait until the demolition activities are completed, then use a suitable vendor to obtain the required material. It is possible at this time to request the present demolition project to perform the required material removal activities. In such a case, a "materials and labor" extension would be given to the present contractor (Olshan) to get the material needed. A scope of work has been formulated that would serve as a basis for a specification to the vendor for the material removal, and is given below.

\section{Scope of Work - Removal of Material from PVRUF}

The work described here is a partial implementation of Task 11.8 of the HSSI Program at ORNL. It should be noted that this is not the final specification for the work, but a request for a cost estimate, since the scope of work will be dictated by cost and funds available. The primary purpose of Task 11.8 is to "survey the variability in chemical composition and fracture properties of the welds in the PVRUF vessel located near Building K-702." Other purposes are to provide test material to other NRC programs, namely the HSST Program and the PNL NDE Program.

The vessel has an external diameter of $16 \mathrm{ft}$ and was fabricated from 9 5/8-in.-thick SA-533 grade B class 1 steel plate (weighing $\sim 400 \mathrm{lb} / \mathrm{ft}^{3}$ ). It is clad on the inside with a weld overlay of $3 / 16-$ to $1 / 4$-in.-thick type 308 stainless steel strip. It is anticipated that the method for material removal will be by means of flame cutting, and following are the requirements on the quality and tolerances of the cuts made in the vessel to provide the needed welds. They are necessary to protect the valuable weld metal needed for research purposes and to reduce future machining costs:

1. The method of cutting must leave an edge with roughness no more than $\pm 0.25 \mathrm{in}$. between any peak to valley resulting from the cutting operation.

2. The distance from the centerline of the weld to the edge of the cut must not be less than and no more than 1 in. over the distance shown on Drawing No. K250010, Rev. 0, i.e., the tolerance on the parts needed is +1 and -0.0 in.

3. The maximum temperature of the welds must not exceed $400^{\circ} \mathrm{F}$. The edge being cut may reach temperatures common in flame cuts.

These requirements must be demonstrated by the vendor using his chosen technique on a large scrap plate of a similar stainless-steel-clad steel of about the same thickness that ORNL will provide. ORNL can also measure the maximum temperature of the weld during cutting.

To accomplish the NRC programmatic tasks, the following subtasks are required:

1. The vendor shall facilitate to HSSI and PNL staff the means to locate the subject welds, by performing the following:

a. The vendor, using a hand sander or grinder, is to remove paint and/or rust and smooth an area about $1 \mathrm{ft}^{2}$ at each of nine locations on the external surfaces of the vessel at the locations indicated in Drawing No. K250010, Rev. 0.

b. The HSSI staff will etch these locations to ensure that the critical welds are indeed at the positions indicated on the vessel drawings.

2. Before any flame cuts are made, the vendor shall stamp the two edges to be parted with 1/2-in. steel letters to uniquely identify their original location in the vessel. This vital step cannot be overemphasized in its importance. The numbering scheme will be transmitted to the vendor.

3. The vendor shall make flame cuts on either side of the two circumferential welds and the three axial welds as shown on the attached drawing. The flame cuts are to be made as follows: 
a. Two 50-ft-long circumferential cuts above and below the nozzle ring to yield the nozzle ring to upper-shell weld. The first cut is to be $10 \mathrm{in}$. above the weld or as close as possible to the nozzles. The second cut is to be 10 in. below the centerline of the nozzle ring to upper-shell weld.

b. Two 50-ft-long cuts for the beltline weld. These cuts are to be 12 in. above and below the centerline of the beltline weld. This separates the upper shell from the vessel.

4. The next set of flame cuts is to segment the nozzle ring to upper-shell weld and beltline rings.

a. The beltline weld is to be cut into approximately ten segments. The exact location for these will be negotiated by HSSI and PNL staff and will be specified beforehand.

b. Only one-half of the ring that contains the nozzle ring to upper-shell weld will be segmented. Our estimate is five segments; the locations will be specified by PNL.

c. On the 7-ft-deep, 16-ft-diam upper shell, cut 84 -in.-wide segments (42 in. on each side of the longitudinal weld at three locations). There will be three $100 \%$ base metal segments remaining.

5. The flame-cut pieces are to be delivered by the vendor to two locations specified below. Lockheed Martin Energy Research Corporation procedures are to be followed for safe on-loading and off-loading of vehicles for transportation.

a. The estimated ten sectors containing the beltline weld and the five designated sectors containing the nozzle ring to upper-shell weld shall be shipped to Building 7025 at ORNL.

b. The vendor shall deliver the three designated 7 -by 7 -ft sectors containing the axial welds to an area near Building 9204-1 at the Y-12 Plant.

6. Since several NRC programs are involved in this effort, the vendor shall provide detailed cost estimates so that the appropriate amounts can be costed to each program.

7. All remaining material from this activity is to be kept at the K-25 site until further instructions.

\section{Option 1: Lower-Shell Axial Welds}

The vendor may be requested to perform the following additional flame cuts to obtain the three axial welds in the lower shell:

1. Locate the three axial welds in the lower shell.

2. Make six 7-ft-long flame cuts on the lower shell, 12 in. on either side of the centerline of the three axial welds. Make a 24-in. cut at the lower end to separate the segments containing the axial welds from the vessel.

3. Provide transportation of the three above segments to the Building 7026 area at ORNL.

\section{Option 2: Base Metal Segments}

Transport one of the three $100 \%$ base metal segments remaining from the upper shell course to the Building 9204-1 area at the Y-12 Plant. 


\subsection{Evaluation of the Precracked Cylindrical Tensile Specimen (D. J. Alexander and R. K. Nanstad)}

The precracked cylindrical tensile (PCCT) specimen is being evaluated by the HSSI Program as a potential alternative specimen for fracture toughness testing in the transition range. Pieces of HSSI weld $72 \mathrm{~W}$ were provided to SRI International and AEA Technology, Harwell, United Kingdom, for testing and analysis.

A draft report describing test results with PCCT specimens of HSSI weld 72W by AEA Technology, Hanwell, has been prepared and will be sent to ORNL in October 1995 for review. The results of SRI and AEA will be compared following receipt of the final AEA report.

The final report from SRI International describing the test methods and results, Fracture Toughness Testing with Cracked Round Bars: Feasibility Study, by J. H. Giovanola and J. E. Crocker [NUREG/CR-6342 (ORNL/Sub/95-DHK60)], has been sent to the Reports Office for publication.

\subsection{Initial Evaluation of Subsize Charpy V-Notch Testing (D. J. Alexander and M. A. Sokolov)}

The final report describing the testing of subsize Charpy specimens, An Improved Correlation Procedure for Subsize and Full-Size Charpy Impact Specimen Data, by M. A. Sokolov and D. J. Alexander [NUREG/CR-6379 (ORNL-6888)], has been sent to the Reports Office for publication.

\section{References}

1. R. K. Nanstad, D. E. McCabe, R. L. Swain, and M. K. Miller, Martin Marietta Energy Systems, Inc., Oak Ridge Natl. Lab., Chemical Composition and $R T_{\text {NDT }}$ Determinations for Midland Weld WF-70, USNRC Report NUREG/CR-5914 (ORNL-6740), December 1992.*

2. D. E. McCabe, R. K. Nanstad, S. K. Iskander, and R. L. Swain, Martin Marietta Energy Systems, Inc., Oak Ridge Natl, Lab., Unirradiated Material Properties of Midland Weld WF-70, USNRC Report NUREG/CR-6249

(ORNLTM-12777), October 1994.*

"Avallable for purchase from National Technical Information Service, Springfield, VA 22161. 


\title{
12. Technical Assistance for JCCCNRS Working Groups 3 and 12
}

\author{
R. K. Nanstad, S. K. Iskander, M. A. Sokolov, and R. E. Stoller
}

The purpose of this task is to provide technical support for the efforts of the U.S.-Russian JCCCNRS Working Group 3 on radiation embrittlement and Working Group 12 on aging. Specific activities under this task are:

(1) supply of materials and preparation of test specimens for collaborative IAR studies to be conducted in Russia;

(2) capsule preparation and initiation of irradiation of Russian specimens within the United States; (3) preparation

for, and participation in, Working Groups 3 and 12 meetings; and (4) sponsoring of the assignment at ORNL of a

scientist from the Russian National Research Center, Kurchatov Institute.

\subsection{Irradiation Experiments in Host Country}

The CVN and round tensile specimens of two Russian weld metals irradiated in HSSI capsule 10.06 at the U. of M. FNR were returned to ORNL. The capsule has been disassembled, specimens identified, and the specimens of Russian steels have been transferred from the disassembly hot cells (Building 3525 ) to the testing hot cells (Building 3025). Some of the specimens will be tested in the irradiated condition while the remainder will be thermally annealed and tested. This testing is anticipated to be completed prior to the end of 1995, depending on funding and scheduling of the next JCCCNRS Working Group 3 meeting.

\subsection{Personnel Interactions}

The HSSI Program is sponsoring the sabbatical of Dr. Mikhail A. Sokolov at ORNL. Dr. Sokolov's areas of concentration are thermal annealing of irradiated reactor pressure vessel steels and the use of subsize Charpy impact specimens for irradiated studies. The results of his research are presented within the particular technical tasks of HSSI semiannual progress reports and published technical reports and papers. 


\section{Correlation Monitor Materials}

\section{W. R. Corwin and E. T. Manneschmidt}

This task has been established with the explicit purpose of ensuring the continued availability of the pedigreed and extremely well-characterized material now required for inclusion in all additional and future surveillance capsules in commercial light-water reactors. Having recognized that the only original materials qualified for use as a correlation monitor in reactor surveillance capsules are the pieces remaining from the early HSST plates 01,02 , and 03 , this task will provide for cataloging, archiving, and distributing the material on behalf of the NRC.

During this reporting period, the remaining correlation monitor materials were moved from the storage area at the Y-12 Plant and placed into the HSSI storage facility at the ORNL site. Two blocks of HSST plate 03 were sent to the Hanjung America Corp. for use as correlation monitor materials in Units 3 and 4 of the Ulchin Nuclear Power Plant in Korea. A detailed reinventory of the correlation monitor materials was initiated after their transfer from the Y-12 Plant to the archival storage location at ORNL. Minor discrepancies between what was anticipated and what was found led to the realization that a small amount of the material still remained at $Y-12$. Preparations were made to transfer the residual material to ORNL.

Additional pieces of HSST plate 03 were distributed to a few added participants in the ASTM cross-comparison exercise on subsize specimen testing technology. The use of the HSST 03 will provide for data from the many varieties of tests to be performed to be compared with the standardized data previously developed. The testing techniques will focus on ways to measure transition temperature and fracture toughness. 


\section{Test Reactor Irradiation Coordination}

\section{W. Heatherly, D. W. Sparks, and K. R. Thoms}

This task was established to supply and coordinate irradiation services needed by NRC contractors other than ORNL. These senvices include the design and assembly of irradiation capsules as well as arranging for the exposure, disassembly, and return of specimens.

Currently, the UCSB is the only other NRC contractor for whom irradiations are to be conducted. These irradiations will be conducted at the $U$. of $M$. in conjunction with other irradiations being conducted for the HSSI Program. When this project was initiated, the plan was to modify the current ORNL U. of M. irradiation capsules to facilitate the irradiation of UCSB specimens. The request from UCSB was to have a high, intermediate, and low flux area in which to irradiate their specimen packets and to have the capability of removing and inserting specimen packets at given intervals in order to obtain desired fluences. It was also requested that each area for irradiation of specimen packets have three axial temperature zones of 260,290 , and $320^{\circ} \mathrm{C}$. Control of the zone temperatures was requested to be within $5^{\circ} \mathrm{C}$ of desired temperature. After several iterations, it was determined that an entirely new facility and capsule design would be necessary to provide UCSB with the desired fluence, temperature, temperature control, and space for the specimen packets to be irradiated.

During this reporting period, the engineering drawings for the mounting base and framework were completed, and a purchase order has been issued for fabrication. The base and framework will be shared by the HSSI-IAR facilities and the HSSI-UCSB facility. It consists of a base plate, thermal shield, and UCSB facility framework. The base plate is used for attaching the facilities to the movable trolley on the East side of the reactor core. The thermal shield, located between the facilities and the reactor core, is the same thickness as has been used in all previous irradiation experiments at the FNR. The thermal shield will contain removable flux monitors for making interval checks on radiation progress and to check the effects of various core loadings. The facility framework is a support structure containing the boral shielding. It will locate and support the UCSB facility between the two IAR facilities.

Engineering drawings were also completed for the specimen capsule baskets. Two basket designs were necessary. The front high-fluence basket will contain up to 16 UCSB specimen packets. The low-andintermediate-fluence basket will be located behind the high-fluence basket. The low-and-intermediate-fluence basket will contain up to 36 full-size and 4 half-size UCSB specimen packets. The specimen baskets are reusable and can be removed and reloaded during refueling shutdowns.

The engineering drawings for the UCSB heated facility were also completed and are now in the review/check stage. The high-fluence section of the heated facility will contain 11 heater zones with a total of 22 electrical heaters and $28 \mathrm{TCs}$ to control and measure the temperature of the specimen packets. The low-and-intermediate-fluence section of the heated facility will contain 7 heater zones with a total of 28 electric heaters and 21 TCs. 


\section{INTERNAL DISTRIBUTION}

1. D. J. Alexander

2. C. A. Baldwin

3. B. R. Bass

4-12. W. R. Conwin

13. D. F. Craig

14. T. L. Dickson

15. K. Farrell

16. F.M. Haggag

17. H. W. Hayden, Jr.

18. D.W. Heatherly

19. J. J. Henry

20. S. K. Iskander

21. J. Keeney

22. E. T. Manneschmidt

23. L. K. Mansur

24. W. J. McAfee

25. D. E. McCabe
26. J. G. Merkle

27. M. K. Miller

28-31. R. K. Nanstad

32. J. V. Pace III

33. W. E. Pennell

34. C. E. Pugh

35. A. F. Rowcliffe

36. R. E. Stoller

37. R. L. Swain

39. K. R. Thoms

40. J. A. Wang

41. ORNL Patent Section

42. Central Research Library

43. Document Reference Section

44-46. Laboratory Records Department

47. Laboratory Records (RC)

48-50. M\&C Records Office

\section{EXTERNAL DISTRIBUTION}

51. ABB-COMBUSTION ENGINEERING, P.O. Box 500, Mail Code 9483-1903, Windsor, CT 60695

S. T. Byrne

52. ATI, Suite 160, 3860 Blackhawk Road, Danville, CA 94506

W. L. Server

53. BABCOCK AND WILCOX, B\&W R\&D Division, 1562 Beeson St., Alliance, $\mathrm{OH} 44601$

W. A. Van Der Sluys

54. BETTIS ATOMIC POWER LABORATORY, Westinghouse Electric Corp., P.O. Box 79, West Mifflin, PA 15122

L. A. James

55. CAROLINA POWER AND LIGHT CO., P.O. Box 1551, Raleigh, NC 27602

S. P. Grant

56. EG\&G IDAHO, INC., P.O. Box 1625, Idaho Falls, ID 83415-2406

V. Shah 


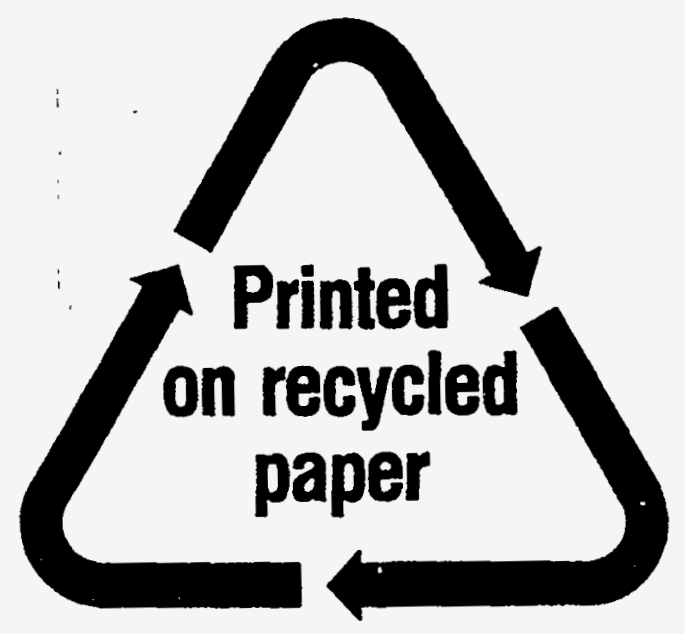

Federal Recycling Program 